Aus der Poliklinik für Zahnärztliche Prothetik

(Prof. Dr. med. dent. Ralf Bürgers)

im Zentrum Zahn-, Mund- und Kieferheilkunde

der Medizinischen Fakultät der Universität Göttingen

Untersuchungen der lokalen Östrogenbiosynthese in Knorpelgewebe und chondrogenen Progenitorzellen in späten Stadien der Arthrose

INAUGURAL - DISSERTATION

zur Erlangung des Doktorgrades

der Medizinischen Fakultät der

Georg-August-Universität zu Göttingen

vorgelegt von

Marcus Reinermann

aus

Coesfeld

Göttingen 2015 
Meiner kleinen Familie

Dekan:

I. Berichterstatter:

II. Berichterstatter:

III. Berichterstatterin:
Prof. Dr. rer. nat. H.K. Kroemer

Prof. Dr. med. N. Miosge

Prof. Dr. Carsten Gründker

Prof. Dr. Margarete Schön

Tag der mündlichen Prüfung: 13.04.2016 


\section{Inhaltsverzeichnis}

1 Einleitung 1

1.1 Arthrose . . . . . . . . . . . . . . . . . . . . . . 1

1.1.1 Ätiologie und Risikofaktoren . . . . . . . . . . . . . . . . . . . 1

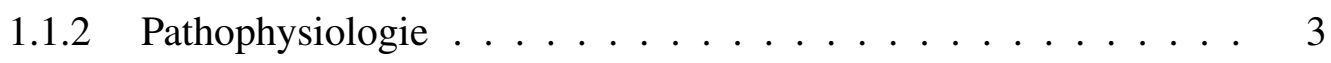

1.1 .3 Diagnostik und Therapie . . . . . . . . . . . . . . 8

1.2 Der Einfluss von Geschlechtshormonen und geschlechtsspezifische Unterschiede in der Entwicklung der Arthrose . . . . . . . . . . . . . . . 99

1.2.1 Lokale Östrogenbiosynthese durch Aromatisierung . . . . . . . . 10

1.3 Chondrogene Vorläuferzellen in fibrokartilaginärem Ersatzgewebe in spä-

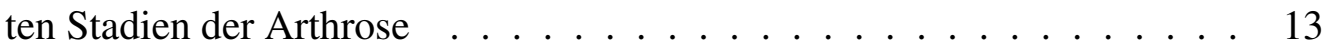

1.4 Ziele dieser Arbeit $\ldots \ldots \ldots \ldots$. . . . . . . . . . . . . . . . . . . . 14

2 Materialien und Methoden 16

2.1 Gewinnung von Knorpelgewebe . . . . . . . . . . . . . . . . . 16

2.2 Zellisolation und Zellkultur . . . . . . . . . . . . . . . . . . . . . 16

$2.2 .1 \quad$ Alginatzellkultur . . . . . . . . . . . . . . 17

2.2 .2 Aromatase-Hemmtest . . . . . . . . . . . . . . . . 17

2.3 Vorbereitung von Knorpelgewebe und primären Zellen in Alginatkultur

für die lichtmikroskopische Immunhistochemie . . . . . . . . . . . . . 18

$2.3 .1 \quad$ Vorbereitung des Knorpelgewebes . . . . . . . . . . . . . . 18

2.3.2 Vorbereitung der in Alginat kultivierten primären Zellen . . . . . 20

2.4 Lichtmikroskopische Immunhistochemie . . . . . . . . . . . . . . . 20

2.4 .1 Allgemeines . . . . . . . . . . . . 20

2.4 .2 Durchführung . . . . . . . . . . . . . . 21

2.5 Polymerasekettenreaktion (PCR) . . . . . . . . . . . . . . 22

2.5 .1 Allgemeines ....................... 22

2.5 .2 Durchführung . . . . . . . . . . . . . . . 25

2.6 Natriumdodecylsulfat-Polyacrylamidgelelektrophorese (SDS-PAGE) und

Western Blot . . . . . . . . . . . . . . . . . . . 32

2.6 .1 Allgemeines ........................ 32

2.6 .2 Durchführung . . . . . . . . . . . . . . 33

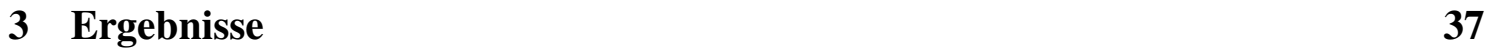


3.1 Nachweis von Aromatase in Knorpelgewebe und chondrogenen Progenitorzellen auf Protein- und mRNA-Ebene . . . . . . . . . . . . . . . . . 37

3.1.1 Immunhistochemischer Nachweis von Aromatase in Knorpelgewebe und in Alginat kultivierten CPC . . . . . . . . . . . . . 37

3.1 .2 Nachweis von Aromatase in CPC mittels Western Blot . . . . . . 43

3.1 .3 Nachweis von Aromatase in CPC auf RNA-Ebene . . . . . . . . 46

3.2 Auswirkungen der Hemmung der lokalen Östrogensynthese auf das regenerative Potential chondrogener Vorläuferzellen . . . . . . . . . . . . 52

$3.2 .1 \quad$ Vorversuche . . . . . . . . . . . . . . . . . . . . 53

3.2.2 Änderungen in der Expression proarthrotischer Gene . . . . . . . 54

3.2.3 Änderungen in der Expression antiarthrotischer Gene . . . . . . . 59

3.2.4 Zusammenfassung der Ergebnisse des Aromatase-Hemmtests . . 61

3.3 Zusammenfassung der Ergebnisse . . . . . . . . . . . . . 62

4 Diskussion 63

4.1 Lokale Östrogenbiosynthese im Kniegelenk in späten Stadien der Arthrose 63

$4.2 \quad$ Expression der Aromatase in chondrogenen Progenitorzellen . . . . . . . 64

4.2.1 Die Expression der Aromatase in chondrogenen Progenitorzellen ist altersabhängig . . . . . . . . . . . . . . . 66

4.2.2 Inhibition der Aromatase in chondrogenen Progenitorzellen aus späten Stadien der Arthrose $\ldots . .68$

4.3 Klinische Relevanz der Arbeit . . . . . . . . . . . . . . . . . . . . 69

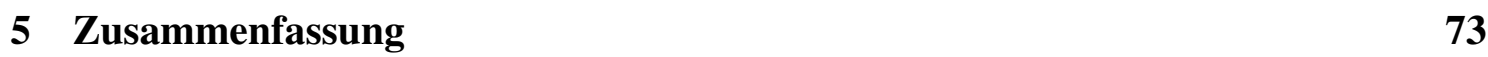

\begin{tabular}{lll}
\hline 6 & Literaturverzeichnis & 74
\end{tabular}

$\begin{array}{lll}7 & \text { Anhang } & \mathbf{8 6}\end{array}$

7.1 Abbildungsverzeichnis . . . . . . . . . . . . . . . . 86

7.2 Tabellenverzeichnis . . . . . . . . . . . . . . . . . . 87

7.3 Symbol- und Abkürzungsverzeichnis . . . . . . . . . . . . . . . . . . 87

7.4 Chemikalien und Materialien . . . . . . . . . . . . . . . . . . . 89

7.5 Geräte- und Softwareverzeichnis . . . . . . . . . . . . . . . . . . 90 


\section{Einleitung}

\subsection{Arthrose}

Die Arthrose (engl. osteoarthritis (OA), Osteoarthrose, Arthrosis deformans) gehört zu den degenerativen Gelenkerkrankungen. Hierbei kommt es zu Verlust des Gelenkknorpels, Verdichtung (Sklerosierung) des subchondralen Knochens mit Ausbildung von knöchernen Auswüchsen (Osteophyten) und einer lokalen Entzündung. Ein Integritätsdefizit des Gelenkes mit Anlauf- und Ruheschmerz sowie eine Einschränkung der Beweglichkeit sind die Folge.

Bei der Arthrose handelt es sich um die weltweit häufigste Gelenkerkrankung (Woolf und Pfleger 2003, Fransen et al. 2011), deren Prävalenz zunehmend ist (Nguyen et al. 2011). Die aktuellsten Schätzungen aus dem Jahre 2008 zur Prävalenz der Arthrose in den USA ergaben, dass etwa $21 \%$ der Bevölkerung an diesem Krankheitsbild litten (Helmick et al. 2008). Untersuchungen an Kohorten aus Asien ergaben ähnliche Prävalenzen (Fransen $e t$ al. 2011). Die von Fuchs et al. 2013 veröffentlichten Ergebnissen der DEGS1-Studie des Robert Koch-Instituts, für die zwischen 2008 und 2011 8.152 Menschen zwischen 18 und 79 Jahren in Deutschland befragt und untersucht worden waren, zeigten bei $20.2 \%$ aller Erwachsenen das Vorliegen einer ärztlich diagnostizierten Arthrose.

Die OA ist die häufigste Ursache für einen prothetischen Ersatz des Knie- und des Hüftgelenkes (Felson et al. 2000), wobei diese Eingriffe auf Platz 7 (Hüftendoprothese) und Platz 20 (Knieendoprothese) der am häufigsten durchgeführten Operationen in Deutschland zu finden sind (Statistisches Bundesamt 2013). So wurden im Jahre 2012 in Deutschland 212.304 Hüftgelenke und 154.792 Kniegelenke durch Endoprothesen ersetzt. Die mit 297.128 Eingriffen am zweithäufigsten durchgeführte Operation in Deutschland steht ebenfalls in Zusammenhang mit der Osteoarthrose. Die „Arthroskopische Operation am Gelenkknorpel und an den Menisken“ ist ein Sammelbegriff für eine Reihe von Maßnahmen, die zu diagnostischen oder therapeutischen Zwecken vor allem im Rahmen der arthrotischen Erkrankung durchgeführt werden.

\subsection{1 Ätiologie und Risikofaktoren}

Es lässt sich eine primäre von einer sekundären Form der Arthrose unterscheiden. Während die Ursache der primären Form unbekannt ist, beruht die sekundäre Form auf be- 
kannten gelenkschädigenden Einflüssen wie Traumata und vermehrter, vor allem nicht physiologischer Beanspruchung des Gelenkes (Böcker et al. 2008).

Als Risikofaktoren für die Entwicklung einer primären Arthrose kommen ein hohes Alter, weibliches Geschlecht (siehe Kapitel 1.2), ein erhöhter Body Mass Index (BMI) oder eine genetische Disposition in Betracht (Felson 1990, Zhang und Jordan 2011).

Mit zunehmendem Alter schwinden die Fähigkeiten des Organismus, gelenkschädigenden Einflüssen zu widerstehen. Durch physiologische Alterungsprozesse kommt es unter anderem zur Abnahme der Muskelkraft und -masse, zu Defiziten in der Propriozeption und zu einer vermehrten Laxizität des Gelenks (Shane Anderson und Loeser 2010). Gealterter Gelenkknorpel kann sich zudem durch veränderte Eigenschaften der zellulären und azellulären Bestandteile nur insuffizient vor schädigenden Einflüssen wie oxidativem Stress oder lokaler Entzündung schützen (Martin und Buckwalter 2001, Sharma et al. 2006). Zudem sind ältere Personen den bekannten Risikofaktoren zur Entwicklung einer Arthrose jahrelang ausgesetzt (Zhang und Jordan 2011).

Die Adipositas, also ein Body Mass Index (Verhältnis von Körpergewicht zu dem Quadrat der Körperoberfläche) von über 30, ist ein starker Risikofaktor zur Entwicklung einer Arthrose vor allem des Kniegelenkes (Murphy et al. 2008, Blagojevic et al. 2010) und der Hand (Berenbaum et al. 2013). Es konnte gezeigt werden, dass gewichtsreduzierende Maßnahmen einerseits zu einer signifikanten Abnahme von subjektiven Gelenkverschleißsymptomen sowie andererseits zu einer Verbesserung von objektivierbaren radiologischen Befunden führten (Felson 1990). In einer klinischen Studie konnten Messier et al. 2004 zeigen, dass die Kombination von Gewichtsreduktion mit zusätzlicher moderater sportlicher Aktivität zu einer effektiveren Reduzierung der Gelenkbeschwerden führte.

Es gilt als erwiesen, dass Verletzungen des Kniegelenkes zu den stärksten Risikofaktoren zur Entwicklung einer OA zählen. So erhöhen vor allem Frakturen mit Gelenkbeteiligung, Meniskusschäden mit der Folge einer Meniskektomie und Verletzungen des vorderen Kreuzbandes die Wahrscheinlichkeit, an einer Arthrose zu erkranken (Zhang und Jordan 2011). Ebenso trägt die chronisch vermehrte Beanspruchung des Gelenks zur Entstehung einer Arthrose bei. So ist die Prävalenz der Erkrankung bei Menschen erhöht, deren Gelenke aufgrund des Berufes einer ausgprägten Belastung ausgesetzt sind. Als besonders gelenkschädigend konnten Arbeiten in kniender Position oder solche, bei denen viel Gewicht getragen wurde, identifiziert werden (Felson et al. 2000).

Weiterhin spielen genetische Polymorphismen in der Ausbildung der primären Arthrose eine Rolle. So wurden unterschiedliche Gene identifiziert, die in Zusammenhang mit der Entwicklung einer Osteoarthritis stehen. Dies sind vor allem Mutationen in Genen, die 
für Proteine kodieren, die strukturelle oder biologische Aufgaben im Gelenk übernehmen, wie zum Beispiel ASPN, CALM1, COL2A1, COMP oder FRZB (Spector und Macgregor 2004). Der Einfluss dieser Gene und die Folgen einer Mutation scheinen zwischen Bevölkerungsgruppen zu variieren (Valdes et al. 2007).

\subsubsection{Pathophysiologie}

Früher wurde die Osteoarthrose als solitäre Pathologie des hyalinen Knorpels angesehen. Mittlerweile betrachtet man sie als Erkrankung des gesamten Gelenks (Loeser et al. 2012), denn neben dem Verlust des hyalinen Knorpels ist ein Umbau des gelenknahen Knochens, eine Destruktion der Meniski und Bänder, sowie eine Hypertrophie der Synovialmembran zu beobachten (Hunter und Felson 2006).

Die Arthrose kann alle Gelenke des menschlichen Körpers betreffen. Gelenke stellen eine Verbindung zwischen Knochen dar, wobei unechte (Synarthrosen) von echten Gelenken (Diarthrosen) unterschieden werden können.

Bei den Synarthrosen sind die Knochen über Knorpel- oder Bindegewebsbrücken fest und meist unbeweglich miteinander verbunden. Beispielhaft seien hier die Membrana interossea zwischen Elle und Speiche als bindegewebige sowie die Synchondrosis sternocostalis zwischen Brustbein und Rippe als knorpelhafte Knochenverbindungen genannt.

Diarthrosen hingegen ermöglichen eine Bewegung der Knochen gegeneinander. Dies wird durch einen mit der sogenannten Synovialflüssigkeit gefüllten Spaltraum ermöglicht. Die miteinander artikulierenden und durch den Gelenkspalt getrennten Knochen bilden mit ihren Enden Gelenkpfanne und Gelenkkopf aus. Pfanne und Kopf sind mit einer Schicht aus hyalinem Knorpel überzogen, der die Knochen vor Druck- und Scherkräften schützt und gleichzeitig ein reibungsarmes Gleiten ermöglicht. Nach außen ist der Gelenkspalt durch die Gelenkkapsel luftdicht abgeschlossen. Die Gelenkkapsel besteht aus einer äuBeren (Membrana fibrosa) und einer inneren Membran (Membrana synovialis), wobei die Zellen der inneren Membran (Synoviozyten) die als Gleitfilm fungierende und den Knorpel ernährende Synovialflüssigkeit produzieren. In manchen Gelenken artikulieren Kopf und Pfanne nicht perfekt miteinander, sodass hier Zwischenscheiben (Meniski oder Diski) in das Gelenk hineinragen und die Unebenheiten ausgleichen (Aumüller et al. 2007). Die Osteoarthrose beginnt am hyalinen Gelenkknorpel. Ursächlich ist hierbei ein Missverhältnis zwischen mechanischer Beanspruchung und der mechanischen Widerstandsfähigkeit des die Enden der Knochen überziehenden Gewebes.

Hyaliner Knorpel gehört neben dem Faserknorpel und dem elastischen Knorpel zum Knorpelgewebe und damit zum Binde- und Stützgewebe des menschlichen Körpers. 
Durch seine enorme Widerstandsfähigkeit gegenüber Druckkräften eignet er sich besonders als Gelenkknorpel. Er ist aber auch als Rippenknorpel zu finden und bildet das Nasenseptum, den knorpeligen Anteil des Kehlkopfes und die Knorpelspangen der Luftröhre aus. Zudem fungiert der hyaline Knorpel während der Skelettentwicklung in der Embryonalperiode als sogenanntes Primordialskelett. Hierbei entsteht aus einem zunächst knorpelig angelegten Knochen durch Umbau Knochengewebe. Dieser Vorgang wird indirekte oder chondrale Ossifikation genannt.

Der gesunde hyaline Knorpel besteht aus kleinen Gruppen basophiler Knorpelzellen (Chondrozyten) und der die Chondrozyten umgebenden und von selbigen synthetisierten extrazellulären Matrix (EZM). Im histologischen Präparat sind die Chondrozyten erkennbar als zu kleinen Gruppen formierte rundliche Zellen, welche jeweils in eine Knorpelhöhle (Lakune) eingebettet sind und von einer Knorpelkapsel umgeben werden. Die Lakune ist ein artifizielles Phänomen, welches bei der Fixation des histologischen Gewebes entsteht und die ursprüngliche Lage des Chondrozyten innerhalb der Knorpelkapsel anzeigt. An die Knorpelkapsel schließt sich nach außen eine basophile Randzone, der sogenannte Knorpelhof, an. Chondrozyten, Knorpelkapsel und Knorpelhof werden zusammen als Chondron bezeichnet (Poole 1999).

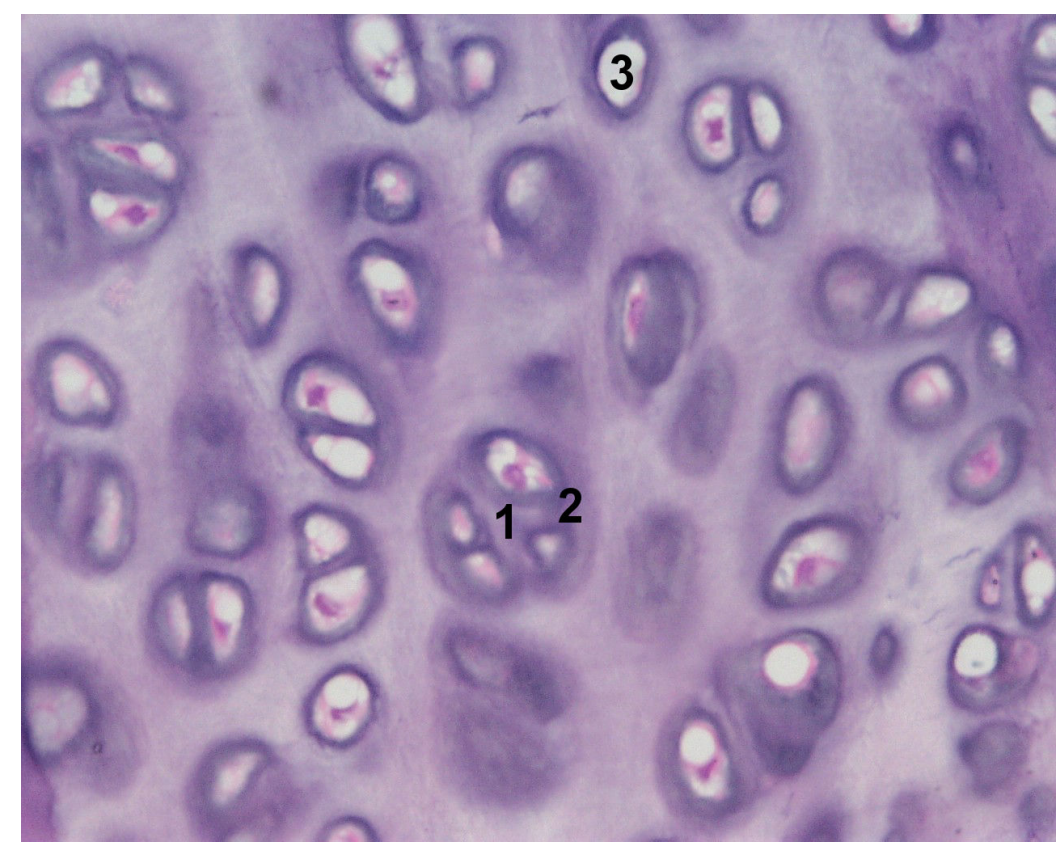

Abbildung 1.1: Hyaliner Knorpel. HE-Färbung. Lichtmikroskopische Aufnahme eines hyalinen Knorpels. Man sieht die zu Chondronen aggregierten Chondrozyten (1), welche jeweils von Knorpelkapsel und Knorpelhof (2) umgeben sind. Weiterhin sind Knorpelhöhlen (3) sichtbar. Entnommen aus: http://histologyolm.stevegallik.org/node/123 (Download: Mai 2013). 
Zwischen den Chondronen befindet sich die EZM, welche hauptsächlich für die Druckelastizität des Knorpels verantwortlich ist und diesem hilft, den im Gelenk wirkenden Kompressions- und Scherkräften zu widerstehen.

Die extrazelluläre Matrix besteht vor allem aus Fasern aus Kollagen 2, welche $40 \%$ des Trockengewichts des Knorpels ausmachen. Kollagen 1 hingegen findet man vor allem in Knochen und Faserknorpel. Die Untereinheit des Kollagens (Tropokollagen) besteht aus drei ineinander verdrehten Proteinhelices. Die einzelnen Tropokollagenmoleküle bilden aneinandergereiht eine Mikrofibrille aus, ein Verbund von Mikrofibrillen wiederum ergibt eine Fibrille, welche den Grundbaustein für eine Kollagenfaser bildet. Diese Ultrastruktur bedingt eine enorme Zugfestigkeit der Kollagene. Die Kollagenfasern verlaufen innerhalb des Gelenkknorpels arkadenförmig (siehe Abbildung 1.3), wodurch die zugfesten Kollagenfasern den im Gelenkspalt herrschenden Druckkräften widerstehen können.

Den zweiten großen Bestandteil der EZM bilden die zur sogenannten Grundsubstanz gehörigen Proteoglykane, wie zum Beispiel Aggrecan. Proteoglykane bestehen aus langen Disaccharidketten (Glykosaminoglykane), welche über Verbindungsproteine an ein zentrales Hyaluronsäuremolekül gebunden sind (siehe Abbildung 1.2). Aggrecan zeichnet sich durch seine gute Wasserbindungsfähigkeit aus und ist damit für die Druckelastizität des hyalinen Knorpels verantwortlich (Junqueira et al. 2005).

Gelenkknorpel lässt sich histologisch in vier Zonen (vgl. Abbildung 1.3) einteilen (Buckwalter et al. 2005):

- Tagentialfaserzone (engl. superficial zone): Oberflächlichste Zone. Die Kollagenfasern verlaufen horizontal, die Chondrozyten haben eine querovale Form und sind parallel zur Oberfläche angeordnet. Die EZM enthält deutlich mehr Kollagen als Proteoglykan, was dieser oberflächlichen Zone eine hohe Widerstandsfähigkeit gegenüber Druck- und Scherkräften verleiht .

- Übergangszone (engl. transitional zone): Die Chondrozyten bekommen eine rundere Form und sind in Chondronen organisiert.

- Radiärzone (engl. radial zone): Die runden Chondrozyten sind säulenartig untereinander angeordnet, die Kollagenfasern verlaufen vertikal. Die Chondrozyten produzieren hier vermehrt Proteoglykane, wodurch die Wasserbindungskapazität, ergo die Druckelastizität der EZM, verbessert wird (Fox et al. 2009). 


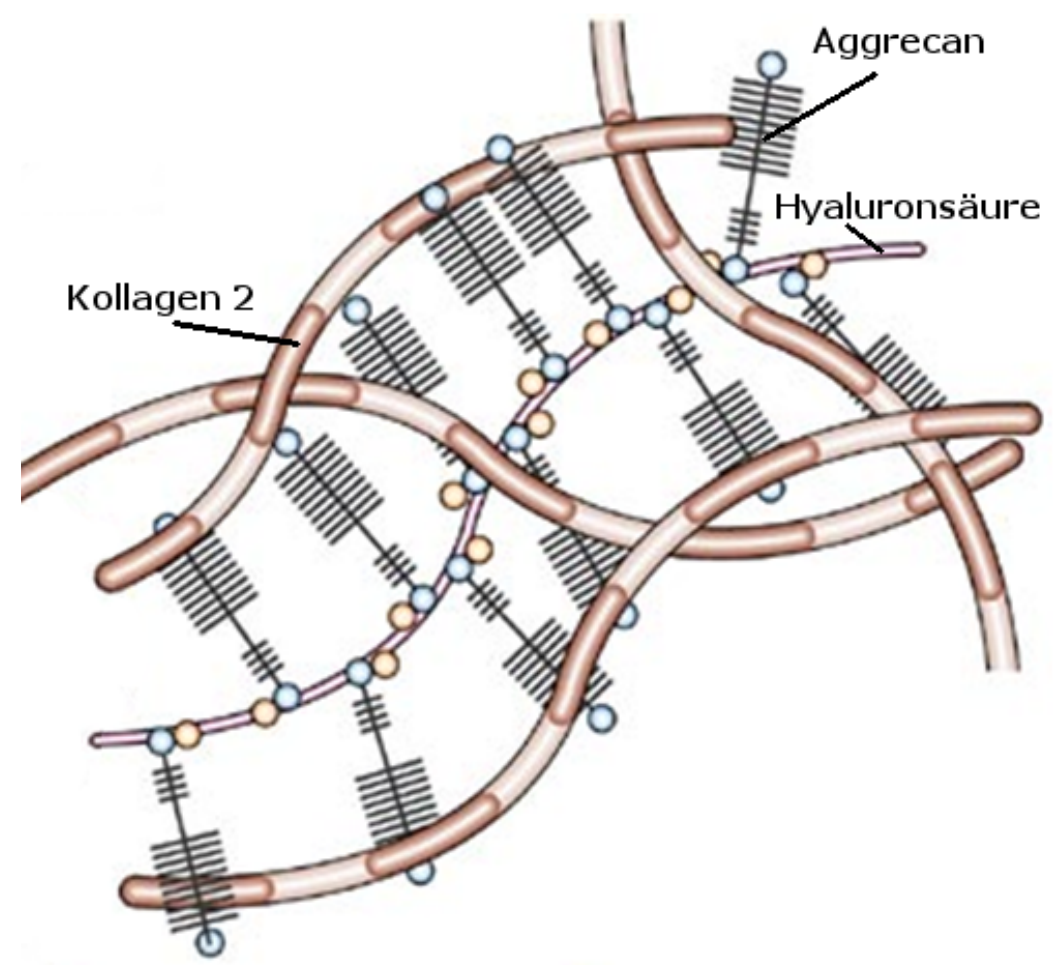

Abbildung 1.2: Bestandteile der EZM (modifiziert nach Chen et al. 2006, S. 374). Schematische Darstellung der Bestandteile der EZM. Man erkennt Kollagenfasern, sowie Aggrecanmoleküle, die über ein Verbindungsprotein mit einem zentralen Hyaluronsäurefaden verbunden sind.

- Mineralisationszone: Übergang zwischen Knorpel und subchondralem Knochen. Hier sind bereits Kalziumkristalle in die EZM eingelagert. Die Tidemark bildet die Grenzschicht zwischen Radiär- und Mineralisationszone aus.

Im Frühstadium der Arthrose kommt es zu einem Abbau der Bestandteile der Extrazellulärmatrix. Dies geschieht enzymatisch unter anderem durch Matrix-Metalloproteinasen (MMP), welche vor allem Kollagene lysieren (Fields 2013), und Aggrecanasen (z.B. ADAMTS (engl. A Disintegrin And Metalloproteinase with Thrombospondin Motifs)).

Matrix-Metalloproteinasen sind eine große Gruppe von Proteinasen, die mithilfe eines zentralen Zinkions Bestandteile der EZM lysieren. Als relativ spezifisch für Knorpelgewebe haben sich die Kollagenasen MMP-1, MMP-8 und vor allem MMP-13 erwiesen (Vincenti und Brinckerhoff 2002, Wang et al. 2013). MMP und Aggrecanasen werden durch die Chondrozyten synthetisiert (Goldring 2012) und sind physiologischerweise unter anderem für den Abbau von extrazellulärer Matrix bei biologischer Adaptation an äußere Einflüsse, wie zum Beispiel Abnahme von muskuloskelettalem Gewebe bei langer Immobilität, aber auch für Angiogenese, Wundheilung und Tumorwachstum verantwort- 


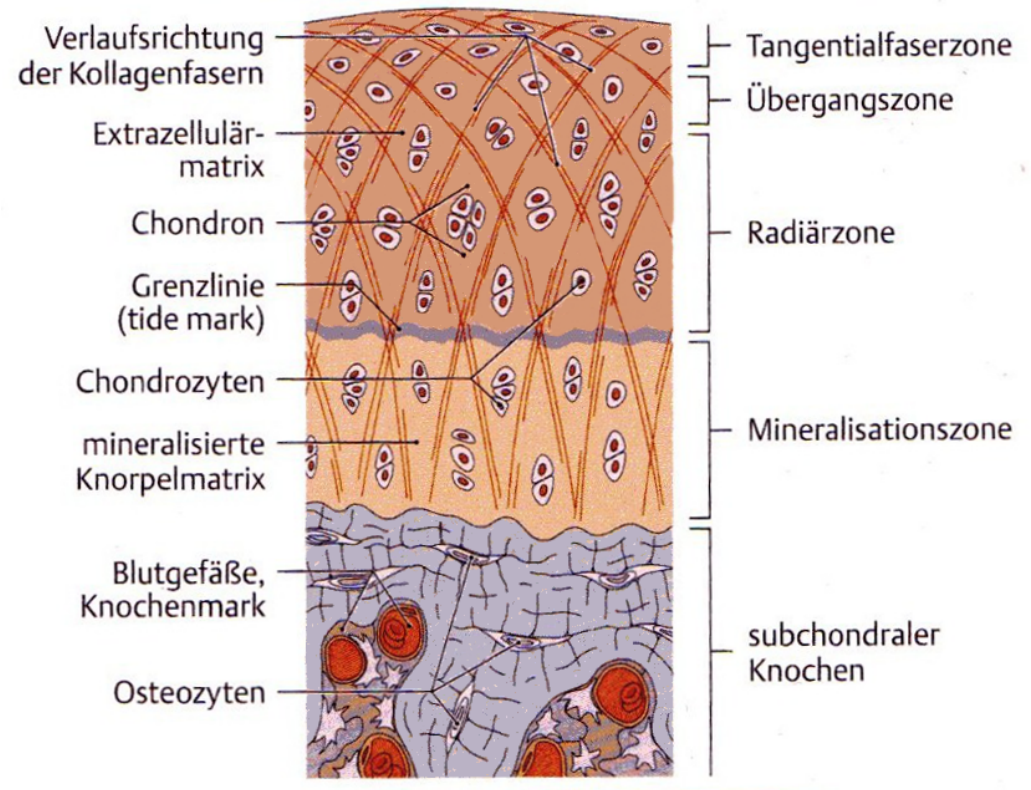

Abbildung 1.3: Schematischer Aufbau des Gelenkknorpels (modifiziert nach Aumüller et al. 200, S. 48). Es wird der zonale Aufbau des Knorpels sichtbar, wobei sich die Chondrozyten in Größe und Form sowie metabolischer Aktivität unterscheiden. Der Verlauf der zugfesten Kollagenfasern innerhalb der Extrazellulärmatrix ist arkadenförmig. Dies bedingt die Druckfestigkeit des hyalinen Knorpels.

lich. MMP beeinflussen zudem direkt den Zellstoffwechsel durch die gezielte Proteolyse von Molekülen aus zellulären Signalkaskaden (Rodriguez et al. 2010).

Bei normaler Beanspruchung befinden sich Auf- und Abbau des Knorpels in einem Gleichgewicht (Goldring 2000), wobei dieses Gleichgewicht je nach Bedarf zugunsten des Anabolismus oder zugunsten des Katabolismus verschoben ist. Diese Homöostase ist bei der Arthrose gestört, es kommt zu einer Überexpression der die Matrix lysierenden Proteinasen. Eine zusätzliche Inflammation durch Zytokine wie Interleukin (IL)-1 $\beta$ oder Tumornekrosefaktor (TNF)- $\alpha$ treibt den katabolen Prozess voran und auch das an diversen Autoimmunerkrankungen beteiligte IL-17 soll in der OA eine Rolle spielen (MartelPelletier 1998).

Im Verlauf kommt es hierbei zunächst zu einer Verschmälerung vor allem der widerstandsfähigen Tangentialfaserzone und später der gesamten EZM. Als Reaktion auf die EZM-Degradation beginnen die Chondrozyten verstärkt kompensatorisch Proteoglykane und Kollagene zu produzieren, sie proliferieren und aggregieren unter dem Einfluss der Wachstumsfaktoren Insuline-Like Growth Factor-1 (IGF-1) und Transforming Growth Factor (TGF), initial zunächst in der Tangentialfaserzone und später im gesamten Knorpel, zu histologisch erkennbaren Zellnestern (Goldring und Marcu 2009). Diese Maßnah- 
men bleiben jedoch insuffizient und daher kommt es unter weiterem Verlust der EZM und konstanter mechanischer Belastung zur Bildung von tiefen, bis zum subchondralen Knochen reichenden Fissuren, zur Apoptose der Chondrozyten, zur Sklerosierung und zum Umbau des subchondralen Knochens (Poole 1999, Sulzbacher 2000, Pritzker et al. 2006). Als weiteres histologisches Zeichen der Arthrose wird eine Duplizierung und Unterbrechung der Tidemark erkennbar, der Grenzschicht zwischen kalzifiziertem und nicht kalzifiziertem Knorpel.

Hyaliner Gelenkknorpel ist ein bradytrophes Gewebe, welches nur durch Diffusion von Nährstoffen aus der Synovialflüssigkeit und aus dem subchondralen Knochen versorgt wird. Der hierdurch bedingte verlangsamte Stoffwechsel erschwert die Reparatur von Knorpeldefekten. Bei schwersten Defekten, die bis an den unter dem Knorpel gelegenen Knochen reichen, setzt eine Narbenbildung durch aus dem Markraum auswachsendes Granulationsgewebe ein. Die in diesem Reparaturgewebe enthaltenen Fibrozyten differenzieren sich und bilden ein fibrokartilaginäres Ersatzgewebe, welches in Zusammensetzung und Eigenschaften dem Faserknorpel ähnelt, aber den hyalinen Knorpel biomechanisch nicht suffizient ersetzen kann.

\subsubsection{Diagnostik und Therapie}

Die Arthrose zeigt eine typische Lokalisationsverteilung, wobei die Wirbel-, Hüft-, Knieund Handgelenke am häufigsten betroffen sind. Die Patienten leiden in den betroffenen Gelenken unter Anlauf- und Ruheschmerz, eingeschränkter Beweglichkeit, Schwellung und Krepitationen (Hunter und Felson 2006). Der Verlust der Gelenkintegrität durch die Mitbeteiligung der anliegenden Bänder und Sehnen resultiert in einer Gelenkinstabilität (Felson 2006).

Die Diagnose wird vor allem klinisch gestellt. Der Patient beschreibt die obigen Symptome in charakteristischen Lokalisationen, wobei der typische arthrotische Gelenkschmerz als Bewegungsschmerz z. B. beim Treppensteigen mit Besserung der Symptomatik in Ruhe beschrieben wird. In späteren Stadien besteht der Schmerz auch in Ruhe und vor allem nachts. Die klinische Untersuchung des betroffenen Gelenkes wird durch radiologische Bildgebung ergänzt, wobei Gelenkspaltverschmälerungen, Geröllzysten, Osteophyten und subchondrale Sklerosierungen auffällig werden (Deutsche Gesellschaft für Orthopädie und Orthopädische Chirurgie 2009). In der Diagnostik werden meist vom American College of Rheumatology eingeführte Klassifikationskriterien (Altman et al. 1986) verwendet, bei denen bestimmte klinsche Symptome und 
radiologische Merkmale dazu beitragen, eine objektive Diagnosestellung zu ermöglichen.

Die Arthrose ist nicht heilbar, deshalb umfasst die Therapie die Aufklärung der Patienten, die Schmerzbekämpfung, die Verbesserung der Gelenkfunktion und das Aufhalten des Voranschreitens der Erkrankung. Konservative Ansätze bestehen aus Gewichtsreduktion und körperlicher Aktivität sowie pharmakologischer Schmerztherapie. Hierbei kommen nichtsteroidale Antirheumatika, in schwereren Fällen in Kombination mit Opioiden, in Betracht. In der akuten Exazerbation mit Zeichen einer lokalen Entzündung zeigten sich durch intraartikuläre Injektionen von Glukokortikoiden kurzfristig Besserungen in der Symptomatik (Bellamy et al. 2009). Bei ausbleibendem Erfolg der konservativen Maßnahmen stehen verschiedene Möglichkeiten zur chirurgischen Therapie zur Verfügung. Wenn frei flottierende Knorpel- oder Meniskusbruchstücke zu mechanischer Irritation führen und damit das Voranschreiten der Arthrose begünstigen, so kann hier eine arthroskopisch durchgeführte Abtragung (Debridement) mit anschließender Spülung (Lavage) therapeutisch sinnvoll sein. Bei Gelenkfehlstellungen kann eine Umstellungsosteotomie die physiologische Gelenkanatomie wiederherstellen. Als therapeutische Ultima ratio der späten Arthrose wird das Gelenk durch eine Endoprothese ersetzt. Ist ein Gelenkersatz nicht möglich, so kann das Gelenk durch eine Arthrodese versteift und damit die schmerzhafte Beweglichkeit aufgehoben werden (Arbeitsgemeinschaft der Wissenschaftlichen Medizinischen Fachgesellschaften 2009). Wie eingangs erwähnt, gehört der endoprothetische Ersatz des Hüft- und Kniegelenkes zu den häufigsten Operationen in Deutschland. Die damit verbundenen ökonomischen und psychosozialen Probleme unterstreichen die Notwendigkeit zur intensiveren Erforschung der grundlegenden pathophysiologischen Mechanismen der Arthrose. Ein detaillierteres Wissen um die im Gelenk ablaufenden Prozesse kann zur Entwicklung speziellerer therapeutischer Maßnahmen führen, welche die Krankheit heilen oder das Voranschreiten verlangsamen könnten, um so die invasive und endgültige chirurgische Intervention möglichst lange hinauszuzögern.

\subsection{Der Einfluss von Geschlechtshormonen und geschlechtsspezifische Unterschiede in der Entwicklung der Arthrose}

Frauen erkranken häufiger an Arthrose als Männer. Nicht nur die Prävalenz und Inzidenz ist bei Frauen höher, bei ihnen scheint die Erkrankung auch einen schwerwiegenderen 
Verlauf zu nehmen (Srikanth et al. 2005). Vor allem Frauen in der Postmenopause leiden häufiger an den Folgen der Arthrose als gleichaltrige Männer (Nevitt und Felson 1996, Wluka et al. 2000). Daher liegt die Vermutung nahe, dass Geschlechtshormone Einfluss auf die Suszeptibilität und den Verlauf der Erkrankung nehmen könnten.

Postmenopausal kommt es zu einer verminderten Östrogenbiosynthese in den Granulosazellen des Ovarialfollikels und damit zu einer erniedrigten Serumkonzentration des Steroidhormons. Eine Korrelation zwischen erniedrigtem Östrogen Serumlevel und einer erhöhten Anfälligkeit für OA bei Frauen (Mahajan et al. 2005, Sowers et al. 2006) konnte nachgewiesen werden. Weiterhin wurden Geschlechtshormonrezeptoren in vielen gelenkbildenden Geweben nachgewiesen, unter anderem auch in Chondrozyten. Das Vorhandensein von Testosteron, seiner Vorstufe Dihydroepiandosteron (DHEA) und Östrogenen wirkte sich protektiv auf den Verlauf der Erkrankung aus. Die Hormone entfalteten antiinflammatorische Effekte (Linn et al. 2012) oder interagierten direkt mit dem Stoffwechsel von Chondrozyten (Claassen et al. 2010, Breu et al. 2011). Hierbei wurden wiederum geschlechtsspezifische Unterschiede beobachtet. So schien die protektive Wirkung von Östrogenen bei Frauen ausgeprägter als bei Männern zu sein (Boyan et al. 2013). Testosteron hingegen übte eine modulatorische Wirkung vor allem auf Chondrozyten aus männlichen Patienten aus (Linn et al. 2012). Zudem gibt es Hinweise darauf, dass die Zufuhr von exogenen Östrogenen im Zuge einer Hormonersatztherapie zur Behandlung von Wechseljahrsbeschwerden, welche heute nur sehr restriktiv aufgrund des breiten Nebenwirkungsspektrums angewandt wird, positive Effekte auf den Verlauf der Arthrose hat. Zusammenfassend lässt sich festhalten, dass es einige Indizien für den positiven Einfluss der Geschlechtshormone und im Speziellen der Östrogene auf die Entwicklung und den Verlauf der Arthrose gibt. Diese Effekte betreffen beide Geschlechter, scheinen aber bei Frauen stärker ausgeprägt zu sein.

\subsubsection{Lokale Östrogenbiosynthese durch Aromatisierung}

Östrogene gehören neben Gestagenen zu den weiblichen Sexualhormonen. Die Hormone werden bei Frauen im gebährfähigen Alter in den Zellen der Ovarialfollikel periodisch produziert und bewirken die Ausbildung der sekundären Geschlechtsmerkmale, den Aufbau der Uterusschleimhaut und die Verminderung der Viskosität des Zervixschleims. Die Östrogene Östron (E1) und Östradiol (E2) werden in den Granulosazellen des Follikels unter Gonadotropineinfluss aus den Androgenen Androstendion bzw. Testosteron synthetisiert und in die Blutbahn abgegeben. Hier sind die Östrogene, wie auch Androgene, zum größten Teil an ein spezifisches Transportprotein, das sogenannte Sexualhormon- 


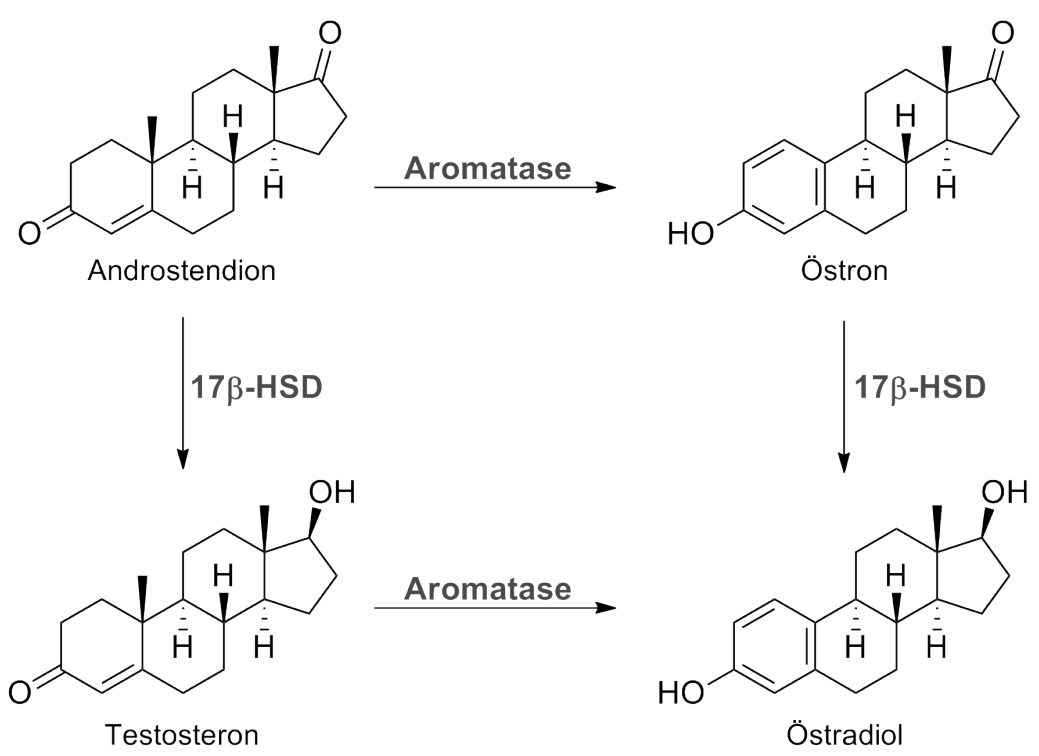

Abbildung 1.4: Durch die Aromatase katalysierte Androgenkonversion. Diese Übersicht zeigt die in den Granulosazellen des Ovarialfollikels und in vielen peripheren Geweben ablaufende Synthese von Östrogenen. Der Ring A des Steroidgerüsts wird hierbei aromatisiert und die Methylgruppe C19 abgespalten (Eigene Abbildung. Erstellt mittels Chemdraw 12.0, PerkinElmer Informatics, Waltham, Massachusetts, USA).

bindende Globulin (SHBG), welches in der Leber synthetisiert wird, gebunden. Nur das nicht gebundene, bioverfügbare Steroidhormon kann an seinem Zielort wirken.

Als Steroidhormone besitzen die Östrogene ein Sterangerüst. Die Synthese der Östrogene aus Androgenen wird durch den Cytochrom P450-Aromatase-Komplex (CYP19, Aromatase) katalysiert. Hierbei wird die Methylgruppe C19 abgespalten und der Ring A des Sterangerüsts aromatisiert (siehe Abbildung 1.4).

Die Aromatase gehört als Hämprotein zur Superfamilie der Cytochrom P450Oxidoreduktasen und gehört somit zu einer Klasse von Enzymen, welche die Oxidation wasserunlöslicher Stoffe katalysieren. Sie wird durch das Gen CYP19 auf Chromosom 15 kodiert und besteht aus 502 Aminosäuren. Über ein Eisen(III)-Ion im aktiven Zentrum des Enzyms und mithilfe von Nicotinamidadenindinukleotidphosphat (NADPH) als Koenzym werden die oben genannten Reaktionen katalysiert (Czajka-Oraniec und Simpson 2010). Die Aromatase ist ein intrazelluläres Protein, welches an der Membran des rauen endoplasmatischen Retikulums lokalisiert ist (Simpson et al. 2002). Die Abbildung 1.5 zeigt die Kristallstruktur des Enzyms. Hier ist das Häm in der Mitte des aktiven Zentrums zu erkennen. 


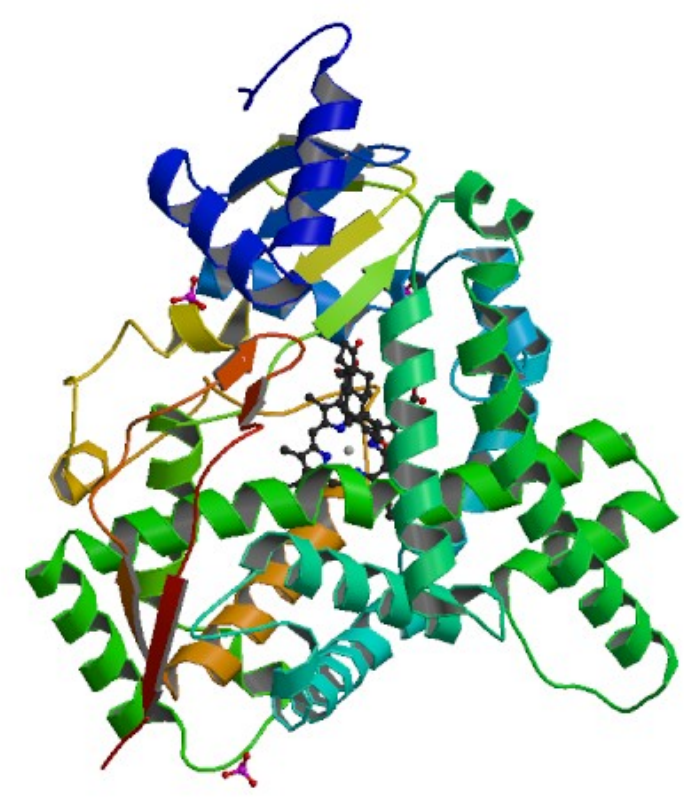

Abbildung 1.5: Kristallstruktur der Aromatase. Kristallstruktur des Enzyms aus humanen Plazentazellen mit einer Auflösung von $2.75 \AA$ (modifiziert nach Ghosh et al. 2012).

Die Aktivität der Aromatase lässt sich über spezifische Inhibitoren aufheben. Bei Östrogen sensitiven Mammakarzinomen kommen neben Antiöstrogenen, wie Tamoxifen, Aromatasehemmer zum Einsatz, um das Angebot an Östrogenen zu verringern. Hierbei lassen sich steroidale Inhibitoren, wie das intramuskulär verabreichbare Formestan oder das orale Exemestan, welche kompetetiv das aktive Zentrum des Enzyms besetzen, von nichtsteroidalen Inhibitoren, wie Anastrozol oder Letrozol, die zu den nichtkompetetiven Antagonisten zählen, unterscheiden (Johnston und Dowsett 2003).

Die Hauptquelle für Östrogene in Männern und in Frauen in der Postmenopause ist die Aromatisierungsreaktion in peripheren, extragonadalen Geweben (Grodin et al. 1973, Simpson 2000). Seine Wirkungen entfalten die weiblichen Geschlechtshormone hier also nicht über eine zentrale Synthese in den Ovarien und die anschließende Verteilung über den Blutkreislauf. Stattdessen werden in der Zona reticularis der Nebennierenrinde gebildete und über die Blutbahn in die Peripherie verteilte Androgene lokal in Östrogene umgewandelt. Hier entfalten die Hormone dann vor allem auto- und parakrine Wirkungen auf die lokalen Gewebe. In den 1970er-Jahren wurde zum ersten Mal gezeigt, dass auch in peripheren Geweben eine Östrogensynthese stattfindet (Santen et al. 2009). So wurde das Fettgewebe als Quelle für eine ausgeprägte extragonadale Östrogenproduktion 
identifiziert. Mittlerweile ist die Aromatase in vielen anderen Geweben wie zum Beispiel Brustgewebe, Muskeln, Gehirn, Leber, aber auch im Knochen (Sasano et al. 1997, Shozu und Simpson 1998), Knorpelgewebe (Simpson et al. 2002) und Synoviozyten (Le Bail et al. 2001) nachgewiesen worden.

\subsection{Chondrogene Vorläuferzellen in fibrokartilaginärem Ersatzgewebe in späten Stadien der Arthrose}

Im Verlauf der arthrotischen Erkrankung werden Teile des zerstörten hyalinen Knorpels durch ein fibrokartilaginäres Gewebe narbig ersetzt. Koelling et al. haben 2009 aus diesem dem Faserknorpel ähnelndem Ersatzgewebe eine Population von multipotenten Vorläuferzellen isoliert, die sogenannten chondrogenen Progenitorzellen (engl. chondrogenic progenitor cells, CPC). Diese zeigen Stammzellcharakteristika wie Migrationsfähigkeit und Klonogenität und sind in der Lage sich unter anderem zu Chondrozyten zu differenzieren. Dabei unterscheiden sie sich in der Synthese von Oberflächenmarkern und bestimmten Proteinen von Osteoblasten, Chondrozyten und mesenchymalen Stammzellen. Zudem exprimieren sie nur in geringem Maße den Stammzellmarker STRO-1, weshalb sie als Progenitorzellen bezeichnet wurden. Weiterhin konnte gezeigt werden, dass die CPC in defekte Areale des hyalinen Knorpels migrieren. Zudem sind sie in der Lage unter partieller Ausschaltung (knockdown) von RUNX2, eines für die osteoblastäre Differenzierung wichtigen Transkriptionsfaktors, vermehrt Kollagen 2 zu exprimieren, das essentielle Kollagen des hyalinen Knorpels. Die chondrogenen Progenitorzellen besitzen also durch ihre Eigenschaften ein großes Potenzial zur Regeneration eines arthrotischen Defektes.

Koelling und Miosge haben daraufhin (Koelling und Miosge 2010) den Einfluss von Geschlechtshormonen auf diese Progenitorzellen untersucht. So exprimieren die CPC die beiden Östrogenrezeptoren ER $\alpha$ und ER $\beta$ sowie den Androgenrezeptor (AR). Es zeigte sich, dass sich physiologische Konzentrationen von Testosteron bei CPC aus männlichen Patienten und prämenopausale Östrogenkonzentrationen bei CPC aus weiblichen Patienten günstig auf das regenerative Potential der Vorläuferzellen auswirkte. Dieses wurde anhand der Expression bestimmter Gene überprüft. So dienten die Gene für Kollagen 2 und SOX9, einem für die chondrogene Differenzierung wichtiger Transkriptionsfaktor, als Marker für Chondrogenität und die Gene für Kollagen 1 und RUNX2 für Osteogeni- 
tät. Unter den obigen Bedingungen zeigten die CPC eine Verbesserung des chondrogenen Potentials durch die Änderung in der Expression der genannten Gene.

\subsection{Ziele dieser Arbeit}

Im Rahmen dieser Arbeit sollte der Stellenwert der lokalen Östrogenbiosynthese in der Arthrose und deren Einfluss auf die chondrogenen Progenitorzellen und ihr Potential zur Regeneration eines Knorpeldefektes weitergehend untersucht werden.

Vor dem Hintergrund des protektiven Einflusses von Östrogenen auf den Verlauf der Erkrankung vor allem bei Frauen (siehe Kapitel 1.2 und der hormonellen Beeinflussbarkeit der chondrogenen Vorläuferzellen und deren potentiellen Defektheilungsfähigkeiten (siehe Kapitel 1.3 stellte sich nun die Frage nach der Quelle des intraartikulären Steroidhormons. Da bei postmenopausalen Frauen, also dem gefährdetsten Patientenkollektiv in Bezug auf die Ausbildung einer Arthrose, aber auch bei Männern, Östron und Östradiol vor allem in der Nähe ihres Zielwirkortes synthetisiert werden und somit vor allem auto- und parakrine Wirkungen entfalten (siehe Kapitel 1.2.1), bestand ein Interesse daran zu überprüfen, ob die hormonsensitiven CPC über die Ausbildung der Aromatase in der Lage seien, eigenständig Östrogene herzustellen um damit über eine autokrine Hormonwirkung den eigenen Stoffwechsel zu beeinflussen. Weiterhin sollte überprüft werden, ob sich in der Quantität der Ausbildung Geschlechtsunterschiede präsentierten, da die CPC geschlechtsspezifisch auf unterschiedliche Hormone reagiert hatten.

Einen weiteren zu untersuchenden Punkt stellte der Einfluss der Hemmung des Aromataseenzyms auf die regenerativen Fähigkeiten der CPC dar. Über Versuche mit einem Aromatasehemmstoff der dritten Generation sollte die Hypothese überprüft werden, ob die CPC durch den fehlenden Östrogeneinfluss z. B. in der Fähigkeit, extrazelluläre Matrixbestandteile des hyalinen Knorpels zu synthetisieren, eingeschränkt werden würden. Dies ist vor allem deshalb interessant, weil es Hinweise auf eine Korrelation zwischen der Gabe von Aromatasehemmern und der Häufigkeit von Gelenkbeschwerden gibt. So klagten Frauen, die aufgrund einer malignen Neoplasie der Mamma mit einem solchen Aromatasehemmer therapiert worden waren, häufiger über Gelenkbeschwerden (Sestak et al. 2008). Weiterhin waren auch bei diesen Experimenten geschlechtsspezifische Unterschiede von Interesse.

Diese Arbeit sollte also dazu beitragen, den Einfluss der lokalen Östrogenproduktion auf die während der späten Arthrose im Gelenk ablaufenden pathologischen Mechanismen und regenerativen Maßnahmen besser zu verstehen. Ein besseres Verständnis dieser Me- 
chanismen wiederum könnte dazu beitragen, effektivere Prävention zu betreiben und gezieltere therapeutische Strategien zu entwickeln. 


\section{Materialien und Methoden}

\subsection{Gewinnung von Knorpelgewebe}

Knorpelgewebe von Patienten in späten Stadien der Osteoarthrose (OA) wurde aus dem Kniegelenk im Rahmen einer Operation zur Implantation einer Totalendoprothese entnommen. Das Knorpelgewebe wurde direkt nach Entfernung in eine 1:1 Mischung aus phosphatgepufferter Salzlösung (engl. phosphate buffered saline, PBS) und Dulbecco's Modified Eagle Medium (DMEM) gegeben und danach sofort weiterverarbeitet. Alle Patienten entsprachen den Klassifikationskriterien des American College of Rheumatology für die Arthrose des Knies (Altman et al. 1986). Sie gaben vor der Operation ihr schriftliches Einverständnis zur Verwendung der Proben und wurden über die Ziele dieser Studie aufgeklärt. Die Studie wurde durch die Ethikkommission der Medizinischen Fakultät der Universität Göttingen genehmigt.

\subsection{Zellisolation und Zellkultur}

Aus den Randbereichen des Knorpelgewebedefektes wurden unter sterilen Bedingungen Präparate der Größe 8-15 mm² entnommen und diese für zehn Tage in mit Kulturmedium gefüllten Zellkulturflaschen unter standardisierten Zellkulturbedingungen kultiviert. Aus dem Knorpel auswachsende Zellen wurden als chondrogene Progenitorzellen (CPC) (Koelling et al. 2009) charakterisiert und für weitere Experimente unter Wechseln des Kulturmediums zweimal pro Woche vermehrt. Kurz bevor die Zellen in der Kulturflasche einen konfluenten Zellrasen ausbildeten, waren sie auf andere Kulturflaschen aufgeteilt und subkultiviert worden. Jede der für die Experimente verwendeten Zelllinien war einbis dreimal derartig passagiert worden.

Nach einer mehrwöchigen Wachstumsphase wurden die Zellen nach Absaugen des Mediums mit PBS-Puffer gewaschen und mechanisch abgelöst. Die Lösung wurde anschließend für $10 \mathrm{~min}$ mit $300 \mathrm{xg}$ zentrifugiert und nach Entfernen des Überstandes wurde das gewonnene Zellpellet in $1 \mathrm{~mL}$ PBS-Puffer resuspendiert. Daraufhin wurde die Zellzahl mithilfe des Zellometers bestimmt. Nach erneutem Zentrifugieren konnten die Zellen weiterverwendet oder bei $-80^{\circ} \mathrm{C}$ aufbewahrt werden. 


\section{Kulturmedium}

$500 \mathrm{~mL}$ DMEM

$50 \mathrm{~mL}$ fetal bovine serum (FBS)

$5 \mathrm{~mL}$ Penicillin / Streptomycin

Da der im DMEM enthaltene pH-Indikator Phenolrot eine Östrogen-mimetische Aktivität besitzt (Berthois et al. 1986), wurde für die Hormonexperimente ein Kulturmedium ohne eben diesen verwendet.

\section{Kulturmedium ohne Phenolrot}

$500 \mathrm{~mL}$ DMEM, no Phenol Red - Gibco 21063-029

$50 \mathrm{~mL}$ fetal bovine serum (FBS)

$5 \mathrm{~mL}$ Penicillin / Streptomycin

\subsubsection{Alginatzellkultur}

Die Kultivierung der Zellen in einer 3D-Alginatumgebung (Häuselmann et al. 1994) wurde wie folgt durchgeführt.

Alle folgenden Lösungen wurden steril filtriert. Zunächst wurden in ein Well einer 6-Well Platte mit einer Fläche von $9 \mathrm{~cm}^{2} 3 \mathrm{~mL}$ einer $102 \mathrm{mM} \mathrm{CaCl}_{2}$-Lösung als essentiellem Bestandteil zur Gelierung des flüssigen Alginats vorgelegt.

Die unter (2.2) erhaltenen Zellen wurden dann in einer Alginatlösung $(1,2 \%)$ suspendiert, sodass in $20 \mu \mathrm{L}$ Alginat etwa 50.000 Zellen enthalten waren. Die Zellsuspension war dann in Volumina von $20 \mu \mathrm{L}$ in die $\mathrm{CaCl}_{2}$-Lösung unter Schwenken pipettiert worden, woraufhin das Alginat zu Kugeln polymerisierte. Nach Entfernung der $\mathrm{CaCl}_{2}$-Lösung wurde zweimal mit Kulturmedium gewaschen. Auf acht Alginatkugeln in einem $9 \mathrm{~cm}^{2}$ großen Well wurden $3 \mathrm{~mL}$ des Kulturmediums pipettiert, welches täglich gewechselt worden ist.

\subsubsection{Aromatase-Hemmtest}

Für die Inhibitionsversuche wurden die primären Zellen (CPC) zunächst für $48 \mathrm{~h}$ in Alginatkultur mit Phenol Red-freiem Medium gehalten. Die Alginatkugeln wurden dann 
gleichmäßig auf vier (oder acht bei sehr vielen Zellen) Wells einer 6-Well Platte aufgeteilt. Einer Zellfraktion wurden dann $10 \mu \mathrm{L}$ einer Testosteronlösung (in Ethanol (96\%, unvergällt) gelöst) zugegeben, um eine Endkonzentration im Well von $100 \mathrm{ng} / \mathrm{L}$ bei Männern und $5 \mathrm{ng} / \mathrm{L}$ bei Frauen zu erreichen. Diese Werte entsprechen den physiologischen Konzentrationen des freien Testosteron im Serum (Werte entnommen aus: Referenzintervalle für Erwachsene, Hinweisheft der Abt. Klinische Chemie der Universitätsmedizin Göttingen 2011). Einer anderen Zellfraktion wurde der Aromataseinhibitor Formestan (Sigma-Aldrich, \#F2552) mit einer Endkonzentration von $100 \mathrm{nmol} / \mathrm{L}$ zugefügt. Dies entspricht dem Serumlevel nach einer Einmaldosis von $500 \mathrm{mg}$ p.o. (Lønning 1998). Im dritten Well wurden beide Substanzen gemischt und die vierte Fraktion diente als Kontrolle. Dieser wurden lediglich $10 \mu \mathrm{L}$ Ethanol (96\%, unvergällt) zugefügt.

Nach einer Inkubationszeit von $24 \mathrm{~h}$ wurden die Zellen mit Medium gewaschen, das Alginat gelöst und die mRNA für die DNA-Amplifikation isoliert.

\subsection{Vorbereitung von Knorpelgewebe und primären Zellen in Alginatkultur für die lichtmikroskopische Immunhistochemie}

\subsubsection{Vorbereitung des Knorpelgewebes}

Aus einem defekten Knorpelareal wurden mithilfe eines Skalpells ca. 1.5 x $1.5 \mathrm{~cm}$ große Knorpelstücke mit darunter liegendem Knochen präpariert und daraufhin in gepuffertes Formalin überführt und über Nacht bei $4{ }^{\circ} \mathrm{C}$ fixiert.

\section{Gepuffertes Formalin, pH 7.4}

$100 \mathrm{~mL}$ Formalin $(37 \%)$

$333 \mathrm{~mL}$ Sørensen-Puffer (0.3 M)

$566 \mathrm{~mL}$ dest. Wasser 


\section{Sørensen Puffer (0.3 M)}

$18.20 \mathrm{~mL} \quad \mathrm{KH}_{2} \mathrm{PO}_{4}$-Lösung (41.37 $\mathrm{g}$ in $1 \mathrm{~L}$ dest. Wasser)

$566 \mathrm{~mL} \quad \mathrm{Na}_{2} \mathrm{HPO}_{4}$-Lösung (42.58 g in $1 \mathrm{~L}$ dest. Wasser)

Anschließend wurden die Präparate zur Entkalkung des anliegenden Knochens in 20\% EDTA überführt und dort für vier Wochen belassen. Die EDTA-Lösung wurde täglich gewechselt.

\section{$20 \%$ EDTA, pH 7.4}

$895 \mathrm{~mL}$ dest. Wasser

$105 \mathrm{~mL} \quad \mathrm{NaOH}(5 \mathrm{M})$

$200 \mathrm{~g}$ EDTA (Sigma-Aldrich, E5134)

Nach vollständiger Entkalkung wurden die Präparate für mindestens einen Tag in $70 \%$ Ethanol überführt und bei $4{ }^{\circ} \mathrm{C}$ gelagert. Die dann folgende Fixierung durch Dehydrierung und Einbettung in Paraffin wurde mithilfe eines Einbettungsautomaten (Duplex Processer, Shandon Elliot, Cheshire, England) durchgeführt.

Tabelle 2.1: Einbettprotokoll

\begin{tabular}{|c|c|c|}
\hline 1 & Ethanol $(70 \%)$ & $3 \mathrm{~h}$ \\
\hline 2 & Ethanol $(80 \%)$ & $1 \mathrm{~h}$ \\
\hline 3 & Ethanol $(90 \%)$ & $1 \mathrm{~h}$ \\
\hline 4 & Ethanol $(96 \%)$ & $1 \mathrm{~h}$ \\
\hline 5 & Ethanol abs. & $2 \mathrm{~h}$ \\
\hline 6 & Isopropylalkohol & $2 \mathrm{~h}$ \\
\hline 7 & Isopropylalkohol & $1.5 \mathrm{~h}$ \\
\hline 8 & Xylol & $30 \mathrm{~min}$ \\
\hline 9 & Xylol & $30 \mathrm{~min}$ \\
\hline 10 & Xylol & $45 \mathrm{~min}$ \\
\hline 11 & Paraplast Plus & $30 \mathrm{~min}$ \\
\hline 12 & Paraplast Plus & $7 \mathrm{~h}\left(60{ }^{\circ} \mathrm{C}\right)$ \\
\hline
\end{tabular}

Die Präparate wurden anschließend aus dem Automaten entnommen und einzeln in Blöcke aus Paraffin eingebettet. Nach Aushärten der Paraffinblöcke konnten mithilfe eines Mikrotoms (Leica, Nussloch, Deutschland) 2-6 $\mu \mathrm{m}$ dicke Schnitte der Präparate angefertigt werden. Diese Schnitte wurden in einem Wasserbad durch Erwärmen $\left(45^{\circ} \mathrm{C}\right)$ gestreckt, um danach glatt auf einen Objektträger aufgezogen zu werden. Danach 
mussten die Gewebeschnitte über Nacht bei $37^{\circ} \mathrm{C}$ getrocknet werden und konnten anschließend für immunhistochemische Untersuchungen weiterverwendet werden.

\subsubsection{Vorbereitung der in Alginat kultivierten primären Zellen}

Die Alginatkugeln wurden zunächst in einer $\mathrm{BaCl}_{2}$-Lösung (10mM) für 20 min bei $4{ }^{\circ} \mathrm{C}$ inkubiert. Anschließend wurden die Alginatkugeln in ein $2 \mathrm{~mL}$ Eppendorfgefäß, welches gepuffertes Formalin enthielt, überführt und bei $4{ }^{\circ} \mathrm{C}$ für $60 \mathrm{~min}$ inkubiert.

Die oben erwähnten Schritte zur Fixierung und Einbettung der Präparate, die durch die Einbettmaschine durchgeführt worden waren, wurden hier analog in Eppendorfgefäßen ausgeführt. Etwa 5-8 Alginatkugeln wurden in einen Paraffinblock eingebettet. Nach dem Schneiden und Aufbringen auf einen Objektträger waren die Präparate bereit für immunhistochemische Untersuchungen.

\subsection{Lichtmikroskopische Immunhistochemie}

\subsubsection{Allgemeines}

Immunhistochemie ist eine Methode zum spezifischen Nachweis von Proteinen auf fixiertem Gewebe, bei der mittels Antikörperreaktion Antigene sichtbar gemacht werden. Hierbei wird ein primärer Antikörper, der gegen das gewünschte Antigen eines Proteins gerichtet ist, auf das zu untersuchende Gewebe gegeben. Ein sekundärer Antikörper, der an die Fc-Region des primären Antikörpers bindet, ist meist mit einem Enzym gekoppelt, welches nach Zugabe eines Substrates eine Chemilumineszenzreaktion katalysiert.

In diesem Fall wurde ein biotinylierter sekundärer Antikörper benutzt. Bei Zugabe des Proteins Streptavidin bildet sich zwischen Streptavidin und Biotin eine nicht-kovalente Bindung aus. Streptavidin wiederum ist an das Enzym Alkalische Phosphatase (AP) gekoppelt. Gibt man nun als AP-Substrat einen Naphtholphosphatester hinzu, so wird dieser hydrolysiert und daraus entstandene Phenole reagieren mit dem ebenfalls hinzugegebenen Chromogen (hier: Fast Red) und es wird Licht emittiert. In diesem Fall rotes Licht.

Zur Darstellung anderer histologischer Strukturen und zur Kontrasterhöhung wird mit einer blauen Lösung (z. B. Hämalaunlösung) gegengefärbt. 


\title{
2.4.2 Durchführung
}

Zunächst wurden die in Kapitel 2.3 erhaltenen Gewebeschnitte entparaffiniert und rehydriert. Dazu wurden die Schnitte zwei mal fünf Minuten in ein Xylolbad getaucht. Danach durchliefen die Schnitte für je drei Minuten eine Alkoholreihe mit sinkender Ethanolkonzentration $(100 \% \rightarrow 96 \% \rightarrow 80 \% \rightarrow 60 \%)$.

Darauf wurde ein Vorverdau mit Citratpuffer durchgeführt, um die durch Formalin hervorgerufenen Proteinvernetzungen zu lösen (Mulisch und Welsch 2010).

Nach einer zehnminütigen Waschphase mit PBS-Puffer (1\%) wurden die Schnitte mit Citratpuffer benetzt und bei $90^{\circ} \mathrm{C}$ für $30 \mathrm{~min}$ inkubiert. Danach folgte ein weiterer Waschschritt.

\section{Citratpuffer}

$18 \mathrm{~mL} \quad \mathrm{C}_{6} \mathrm{H}_{8} \mathrm{O}_{7}$-Lösung (4.2 $\mathrm{g}$ in $200 \mathrm{~mL}$ dest. Wasser)

$82 \mathrm{~mL} \quad \mathrm{C}_{6} \mathrm{H}_{5} \mathrm{Na}_{3} \mathrm{O}_{7} \cdot 2 \mathrm{H}_{2} \mathrm{O}$-Lösung (29.40 g in $1000 \mathrm{~mL}$ dest. Wasser)

$900 \mathrm{~mL}$ dest. Wasser

\section{Phosphatgepufferte Salzlösung (PBS)}

\author{
$8.18 \mathrm{~g} \mathrm{NaCl}$ \\ $0.20 \mathrm{~g} \mathrm{KCl}$ \\ $1.60 \mathrm{~g} \quad \mathrm{Na}_{2} \mathrm{HPO}_{4}$ \\ $0.20 \mathrm{~g} \quad \mathrm{KH}_{2} \mathrm{HPO}_{4}$ \\ $100 \mathrm{~mL}$ dest. Wasser
}

Als Vorbereitung für die nun folgenden Antikörperreaktionen wurde zehn Minuten in einer Rinderserumalbumin (engl. bovine serum albumin, BSA)-PBS-Lösung (1\%) inkubiert, um unspezifische Bindungsstellen zu blocken.

Anschließend wurde auf jeden Gewebeschnitt etwa $100 \mu \mathrm{L}$ des Primärantikörpers (Mouse anti human cytochrome P450 Aromatase. AbD Serotec, Oxford, UK. Turner et al. 2002) in einer Verdünnung von 1:100 (gelöst in PBS) pipettiert und über Nacht bei Raumtemperatur inkubiert. Einige Gewebeschnitte fungierten als Negativkontrolle, indem sie anstatt mit dem Primärantikörper lediglich mit PBS benetzt wurden. Danach 
erfolgte ein weiterer Waschschritt in PBS. Für die folgenden Schritte wurde das Dako REAL Detection System (Dako, K5005) genutzt und es wurde nach Herstellerangaben verfahren. Die Inkubationszeiten waren wie folgt: Biotinylierter sekundärer Antikörper 1 h; Streptavidin/AP - 30 min; Chromogen - 5 min unter Ausschluss von Licht. Zwischen jedem Schritt und nach der Chromogenzugabe wurde erneut in PBS gewaschen.

Abschließend wurden die Schnitte für etwa 1-3 Minuten in einer Hämalaunlösung gegengefärbt und zehn Minuten unter fließendem Wasser gereinigt.

\section{Hämalaun Färbelösung}

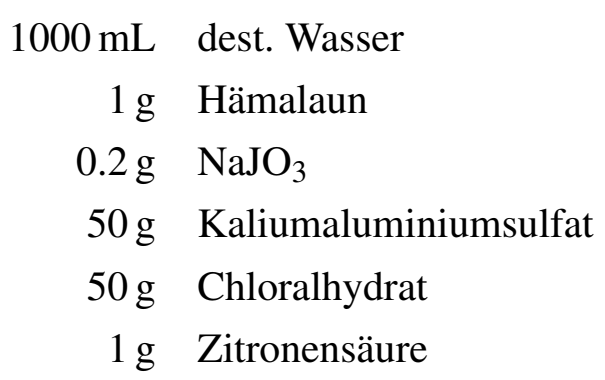

Zuletzt folgte die Dehydrierung der Schnitte durch obige Alkohol-/Xylolreihe in umgekehrter Reihenfolge und das Aufbringen von Deckgläschen mittels Eukitt-Kleber.

Die spezifisch für die Aromatase gefärbten Gewebeschnitte konnten unter einem Lichtmikroskop betrachtet werden.

\subsection{Polymerasekettenreaktion (PCR)}

\subsubsection{Allgemeines}

Die Polymerasekettenreaktion (engl. polymerase chain reaction, PCR) ist eine Methode zur Amplifizierung spezifischer DNA-Sequenzen durch eine in vitro durchgeführte DNA-Replikation.

Um Gene untersuchen zu können, die tatsächlich transkribiert und translatiert werden (also Proteine codieren), wird nicht die gesamte im Nucleus befindliche DNA (genomische DNA, gDNA) amplifiziert. Vielmehr wird das nach dem Spleißen entstandene Produkt, also die nur Exons enthaltende mRNA isoliert und in die komplementäre DNA (engl. complementary DNA, cDNA) umgeschrieben. Die mRNA wird aus primären Zellen (mittels RNeasy Kit) isoliert und mithilfe einer reversen Transkriptase in cDNA 
umgeschrieben.

Für die PCR werden folgende Werkzeuge benötigt:

- eine cDNA-Matrize (Template)

- eine hitzebeständige (taq-)Polymerase

- zwei verschiedene Primer, die nach Anlagerung an die komplementäre cDNA den zu vervielfältigenden Bereich zwischen sich einschließen.

- dNTPs

- Puffer $\left(\mathrm{MgCl}_{2}\right)$

- interkalierender Farbstoff (hier: SYBR-Green)

Nachdem diese Komponenten zusammen pipettiert worden sind, übernimmt ein Thermocycler (hier: Eppendorf Mastercycler) das Erhitzen bzw. Herunterkühlen der Probe auf die im Folgenden erwähnten Temperaturen. Hierbei wiederholen sich drei Schritte, die einen Zyklus ausmachen:

1. Denaturierung/Initialisierung: Die Matrizen-cDNA wird durch Erhitzen auf $95^{\circ} \mathrm{C}$ in Einzelstränge aufgetrennt. Die hitzebeständige Polymerase wird hierbei nicht geschädigt.

2. Hybridisierung (Annealing): Die Primer lagern sich bei ihrer spezifischen Annealing-Temperatur an den komplementären Bereich des DNA-Einzelstrangs an.

3. Verlängerung (Extension): Die taq-Polymerase bindet bei $72^{\circ} \mathrm{C}$ an die Primer und verlängert diese in 5'-Richtung.

Dieser Zyklus wird nun etwa 40 Mal wiederholt, wobei sich unter idealen Bedingungen die gewünschte DNA mit jedem Zyklus verdoppelt. Der oben erwähnte Farbstoff (SYBR-Green), der mit der DNA interkaliert, dient zum quantitativen Nachweis der DNA. Er ist zunächst inaktiv und wird über die Einlagerung in die DNA über Komplexbildung aktiviert und emittiert grünes Licht. Erhöht sich die Zahl der zu amplifizierenden DNA-Sequenz von Zyklus zu Zyklus, so nimmt auch die Menge 
an DNA-Fluoreszenzfarbstoff-Komplexen zu. Diese Zunahme der Fluoreszenz kann gemessen werden. Wichtig für die (relative) quantitative Bestimmung des DNA-Gehaltes der Probe ist ein bestimmter Zyklus $(\mathrm{Ct}=$ threshold cycle $)$, an dem eine festgelegte Fluoreszenzschwelle überschritten wird. Hier übersteigt die Fluoreszenz zum ersten Mal signifikant die Hintergrundfluoreszenz (vgl. Abbildung 2.1). Je früher diese Fluoreszenzschwelle erreicht wird, desto größer war die Ausgangsmenge der cDNA in der Probe. Unter idealen Bedingungen, wenn es also tatsächlich in jedem Zyklus zu einer Verdopplung der cDNA kommt, besitzt z. B. Probe A, bei der die Fluoreszenzschwelle bei $\mathrm{Ct}=$ 22 erreicht wird, doppelt so viel DNA wie Probe B, bei der die Fluoeszenzschwelle bei $\mathrm{Ct}=23$ erreicht wird.

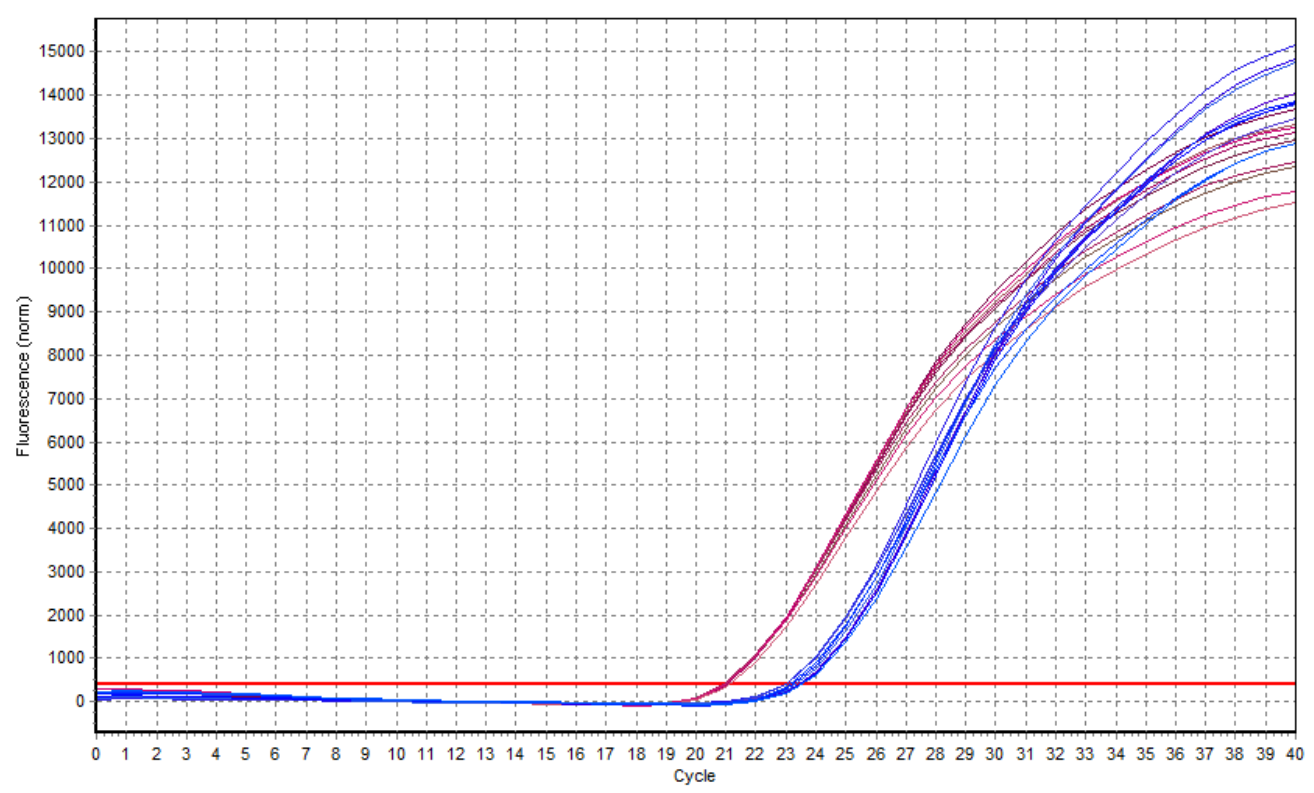

\begin{abstract}
Abbildung 2.1: Ergebnis eines PCR-Durchlaufs. Beispielhaft das Ergebnis eines PCR Durchlaufs. Auf der X-Achse sind die Zyklen, auf der Y-Achse die Fluoreszenzintensität abgebildet. Die Probe (unstimulierte chondrogene Progenitorzellen) wurde auf zwei Gene, dessen Primer dieselbe Annealing-Temperatur benutzten, getestet. Die Kurven der beiden DNA-Amplifikate kreuzen zu unterschiedlichen Zeitpunkten den Schwellenwert (rote horizontale Linie). Die beiden Gene in der Probe werden verschieden stark exprimiert.
\end{abstract}

Pro zu untersuchendem Gen werden drei PCR-Durchläufe durchgeführt, wobei in jedem Durchlauf drei Proben gleichzeitig untersucht werden. Die Ct-Werte der Läufe werden gemittelt und es wird die Standardabweichung bestimmt. Die so gemittelten $\mathrm{Ct}$-Werte werden daraufhin auf eine Kontrolle bezogen, um die relative Expression des zu untersuchenden Gens zu bestimmen. Über einen zusätzlichen Vergleich (Normalisierung) 
des gemittelten Ct-Wertes der Probe mit dem einer internen Kontrolle (Pfaffl 2001) können Störfaktoren wie Gewebe- und Matrixeffekte oder Fehler in der RNA-Extraktion beziehungsweise der Transkription minimiert werden, da diese Faktoren sowohl das Zielgen als auch das Kontrollgen betreffen. Als interne Kontrolle wird ein „Housekeeping Gen“ benutzt, also ein Gen, dessen Translationsprodukt im basalen Zellstoffwechsel eine Rolle spielt und dessen Genexpression unabhängig von äußeren Einflüssen ist.

Um die Effizienz der Polymerasekettenreaktion zu überprüfen, welche ein Maß der Güte der Amplifikation darstellt, wird ein Housekeeping-Gen in einer standardisierten Verdünnungsreihe amplifiziert und die ermittelten Ct-Werte halblogarithmisch gegen die eingesetze Menge an cDNA aufgetragen. Aus der Standardkurve kann daraufhin die Effizienz der PCR berechnet werden, welche ebenfalls in die von Pfaffl publizierte Berechnung der relativen Expression (Ratio) eingeht.

Um zwischen unterschiedlichen PCR-Produkten unterscheiden zu können und um die Spezifität der Primer zu überprüfen, wird am Ende eines Durchlaufs eine Schmelzkurvenanalyse durchgeführt. Hierbei wird die Temperatur langsam erhöht, wobei es bei einer für eine DNA-Sequenz bestimmte Schmelztemperatur (je länger die Sequenz und je größer der Guanin/Cytosin-Anteil, desto höher die benötigte Temperatur) zur Denaturierung des Doppelstrangs und damit zur Abnahme der Fluoreszenz kommt.

\subsubsection{Durchführung}

\section{RNA-Isolation aus primären Zellen}

Aus den zuvor gezählten und zu Pellets verarbeiteten Zellen wurde mithilfe des RNeasy Mini Kits (Qiagen) die mRNA isoliert.

Zum Aufschluss der Zellen wurde das Zellpellet in einem Gemisch aus $350 \mu \mathrm{L}$ eines Guanidin-Thiocyanat enthaltenden Lysepuffers (RLT-Puffer) und $3.5 \mu \mathrm{L} \beta$ Mercaptoethanol suspendiert und für zwei Minuten bei Raumtemperatur inkubiert. Daraufhin wurde die Zellsuspension durch Auftragen auf eine Qiagen Shredder Säule und anschließender Zentrifugation bei 14000 x g für zwei Minuten homogenisiert. Anschließend sind $350 \mu \mathrm{L} 70 \%$ Ethanol hinzugegeben, das Gemisch auf eine RNeasy Mini-Säule pipettiert und dann $15 \mathrm{~s}$ bei $8000 \mathrm{x}$ g zentrifugiert worden. Hierbei hat sich die mRNA an die in der Säule enthaltene Silikatmembran gebunden, während die anderen Zellbestandteile sowie das Puffer-Ethanolgemisch im Durchlauf verblieben. Dieser wurde verworfen. Die Membran wurde nun mehrfach mit Waschpuffern mittels 
Zentrifugation gereinigt.

Zunächst wurden $700 \mu \mathrm{L}$ des RW1-Puffers hinzugegeben, $15 \mathrm{~s}$ bei $8000 \mathrm{x}$ g zentrifugiert und der Durchlauf verworfen. Danach sind $500 \mu \mathrm{L}$ des RPE-Puffers aufgetragen, $15 \mathrm{~s}$ bei 8000 x g zentrifugiert und der Durchlauf verworfen worden. Dieser Schritt wurde dann mit einer Zentrifugationszeit von zwei Minuten wiederholt. Daraufhin wurde abermals bei $14000 \mathrm{xg}$, ohne einen Puffer aufzutragen, zentrifugiert, um eventuelle Rückstände eines Puffers von der Membran zu entfernen. Die so getrocknete Säule wurde dann auf ein Biopur $1.5 \mathrm{~mL}$ Eppendorfgefäß gegeben und die Membran mit $50 \mu \mathrm{L}$ RNAse freien Wassers benetzt. Nach fünfminutiger Inkubation, in der sich die membrangebundene mRNA im Wasser gelöst hatte, wurde erneut bei $14000 \mathrm{x}$ g für eine Minute zentrifugiert. Der Durchlauf enthielt nun die gewünschte RNA.

Die Konzentration der mRNA wurde UV-spektroskopisch mittels Nano Drop 1000 Spectrophotometer (Thermo Fisher Scientific, Welmington, USA) durch Absorptionsmessung bei $260 \mathrm{~nm}$ ermittelt. Um die Reinheit der Probe anzugeben, wurde zudem bei $230 \mathrm{~nm}$ und bei $280 \mathrm{~nm}$ gemessen und diese Werte in ein Verhältnis mit der Extinktion bei 260nm gesetzt. Das Verhältnis $260 \mathrm{~nm} / 280 \mathrm{~nm}$ sollte für RNA bei etwa 2.0 liegen. Ein niedrigerer Absorptionswert deutet auf eine Verunreinigung durch Proteine, Phenol oder andere Stoffe hin, deren Absorptionsmaximum bei $280 \mathrm{~nm}$ liegt. Das Verhältnis $260 \mathrm{~nm} / 230 \mathrm{~nm}$ sollte bei etwa 1.8-2.2 liegen. Ein niedrigerer Wert spricht ebenfalls für Verunreinigungen.

Für die RNA-Isolation aus den in einer 3D-Umgebung kultivierten Zellen wurde nach Entfernung des Kulturmediums ein HEPES-EDTA-Puffer zugefügt, der durch Komplexbildung mit dem Calcium das Alginat wieder verflüssigte. Nach Zentrifugation und Absaugen des Überstandes waren die Zellen als Pellet für die RNA-Extraktion weiter zu verwenden.

\section{HEPES-EDTA-Puffer}

$\begin{aligned} 2.05 \mathrm{~g} & \text { EDTA } \\ 0.60 \mathrm{~g} & \text { HEPES } \\ 100 \mathrm{~mL} & \text { dest. Wasser }\end{aligned}$




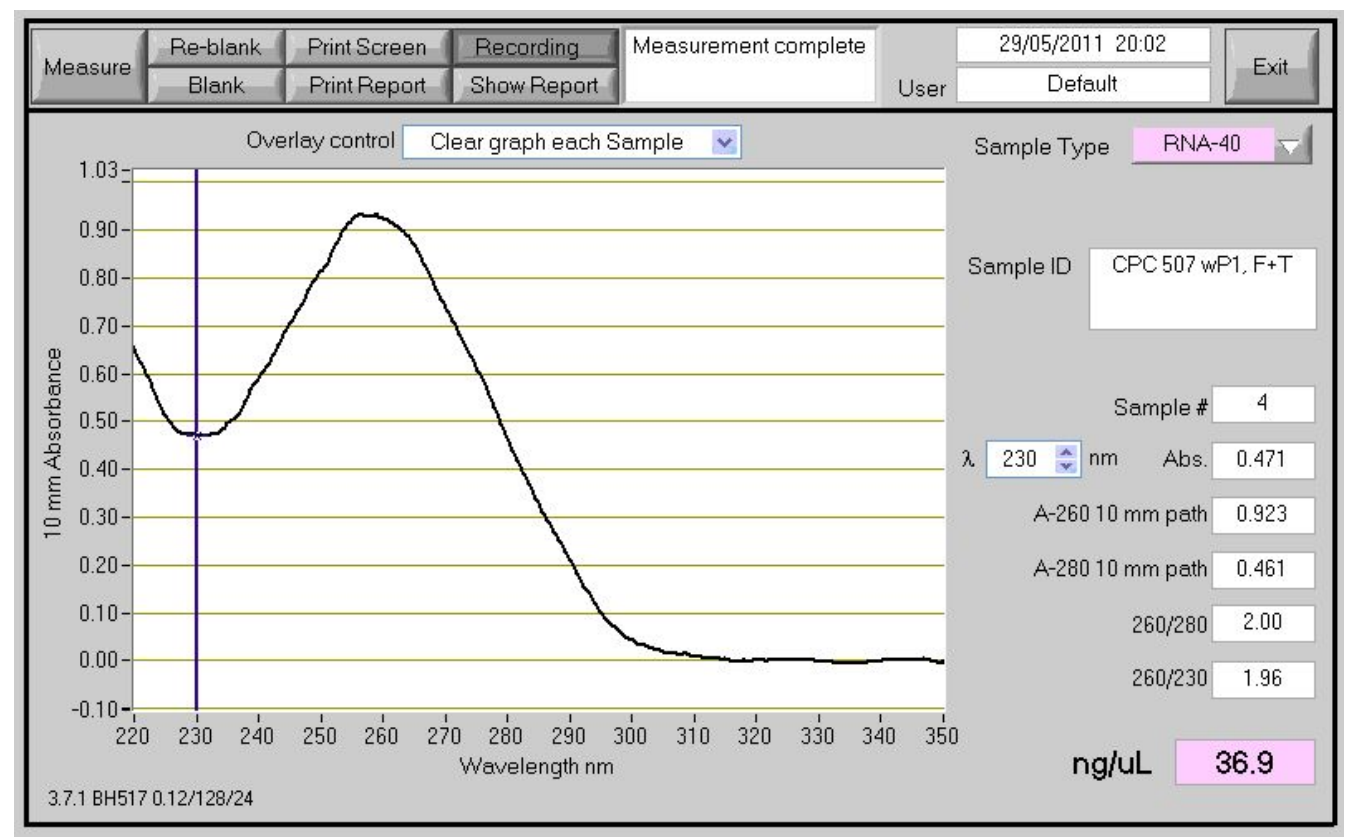

Abbildung 2.2: Messung der mRNA-Konzentration. Exemplarisch eine Messung mit dem Nano Drop 1000. Rechts unten wird die RNA-Konzentration der Probe angezeigt, Die Verhältnisse 260/280 und 260/230 bestätigen die Reinheit der Probe.

\section{cDNA-Synthese}

Die Synthese der cDNA aus mRNA geschieht mittels Reverser Transkriptase, einem Enzym, das die mRNA als Matrize zur Herstellung von komplementärer DNA benutzt.

Zur Herstellung der cDNA wurde das QuantiTect Reverse Transcription Kit (Qiagen, Venlo, Niederlande) verwendet. Zunächst wurden hierzu $200 \mathrm{ng}$ der mRNA (zuvor per Nano Drop bestimmt) mit $2 \mu \mathrm{L}$ des gDNA Wipeout Buffers vermischt und daraufhin mit RNAse freiem Wasser auf $14 \mu \mathrm{L}$ aufgefüllt. Die Lösung wurde dann bei $42^{\circ} \mathrm{C}$ für zwei Minuten inkubiert, um eventuelle Verunreinigungen durch genomische DNA (gDNA) zu beseitigen. Daraufhin wurde der Probe $1 \mu \mathrm{L}$ RT-Primer-Mix, $4 \mu \mathrm{L}$ Quantiscript RT Buffer sowie $1 \mu \mathrm{L}$ der Reversen Transkriptase (Quantiscript Reverse Transcriptase) — alle drei Reagenzien wurden zuvor als Mastermix vorbereitet - zugefügt und für 15 min inkubiert. Zur Inaktivierung der Reversen Transkriptase wurde die Probe für drei bis fünf Minuten auf $95^{\circ} \mathrm{C}$ erhitzt. Ausgehend von einer idealen Transkription erhielt man als Produkt der Umschreibung aus $200 \mathrm{ng}$ mRNA ebenso viel cDNA. Durch Zugabe von $180 \mu \mathrm{L}$ RNAse-freiem Wasser wurde die Probe auf eine Endkonzentration der cDNA von $1 \mathrm{ng} / \mu \mathrm{L}$ verdünnt. 


\section{Primerdesign}

Die Primer wurden anhand der bekannten DNA-Sequenz (einsehbar in den Gendatenbanken der National Center for Biotechnology Information, Bethesda, USA (http://www.ncbi.nlm.nih.gov (2011)) mithilfe des Primer3 Webinterfaces (http://primer3.wi.mit.edu (2011)) erstellt. Die so erstellten Primer enthielten eine Länge von etwa 20 Basen und einen Guanin/Cytosin-Anteil (CT-Anteil) von $50 \%$. Anschließend folgte eine Überprüfung der Primersequenzen durch einen Vergleich mit dem menschlichen Genom mittels Basic Local Alignment Search Tool (BLAST) (http://blast.ncbi.nlm.nih.gov (2011)). Jene Primer, die zu 100\% spezifisch für das $\mathrm{zu}$ amplifizierende Gen waren, wurden weiterverwendet. Um zu verhindern, dass es durch einen Loop $\mathrm{zu}$ einer Anlagerung des Primers an sich selbst kommt, wurden die Sequenzen schließlich mittels Oligocalc-Programm (http://www.basic.northwestern.edu/biotools/oligocalc.html (2011)) auf Selbstkomplementarität überprüft. Daraufhin wurden die Primer von der Firma Operon Biotechnologie GmbH (Operon Biotechnologie GmbH, Köln, Deutschland) synthetisiert. Die lyophilisiert gelieferten Primer wurden nach Herstellerangaben in Nuklease-freiem Wasser in einer Konzentration von $100 \mathrm{pmol} / \mu \mathrm{L}$ suspendiert. Zur einfacheren Handhabung wurden Vorwärts- und Rückwärtsprimer in einer Verdünnung von 1:10 zusammen aliquotiert (Endkonzentration Primer: $10 \mathrm{pmol} / \mu \mathrm{L}$ ), im Folgenden Primer-Mix genannt.

Die Primer für das Aromatase-Gen wurden eigenhändig erstellt, die anderen verwendeten Primer (siehe Tab. 3.2) wurden aus dem Bestand der AG Orale Biologie und Geweberegeneration, Abteilung Prothetik, UMG Göttingen entnommen und können auch unter http://www.miosge.med.uni-goettingen.de unter dem Reiter „Forschung“ und dann „Primer" eingesehen werden (2012).

Tabelle 2.2: Auflistung der verwendeten Primer

\begin{tabular}{|c|c|c|c|}
\hline Zielgen & Sequenz Vorwärts & Sequenz Rückwärts & Annealing-Temperatur \\
\hline \hline Aggrecan & acagctggggacat & gtggaatgcagagg & $60^{\circ} \mathrm{C}$ \\
\hline Aromatase & acaccagagaaccaggctaca & ccttgggttgaggcagtaga & $62^{\circ} \mathrm{C}$ \\
\hline Kollagen 1 & ttcccccagccacaaagagtc & cgtcatcgcacaacacct & $61^{\circ} \mathrm{C}$ \\
\hline Kollagen 2 & ctcctggagcatctggagac & accacgatcaccttgactc & $63^{\circ} \mathrm{C}$ \\
\hline HPRT1 & tgacactggcaaaacaatgca & ggtcctttcaccagcaagct & $61^{\circ} \mathrm{C}$ \\
\hline MMP13 & ctatggtccaggagatgaa & agagtcttgcctgtatcct & $63^{\circ} \mathrm{C}$ \\
\hline RUNX2 & ttccagaccagcagcactc & cagcgtcaacaccatcatt & $63^{\circ} \mathrm{C}$ \\
\hline SOX9 & caggctttgcgatttaaggaa & ccgtttaaggctcaaggtg & $60^{\circ} \mathrm{C}$ \\
\hline
\end{tabular}




\section{Bestimmung der Annealing-Temperatur}

Um die für den Primer spezifische Annealing-Temperatur herauszufinden, wurde eine Gradienten-PCR durchgeführt, bei der empirisch die günstigste Annealing-Temperatur bestimmt worden ist. Dazu wurden acht Temperaturen getestet und daraufhin die Schmelzkurven analysiert. In der 1. Ableitung der Schmelzkurve für die beste AnnealingTemperatur sollte ein Gipfel zu sehen sein (d.h. es entstand nur ein Produkt) und dieser Peak sollte am höchsten sein (d.h. bei dieser Temperatur gelang die Hybridisierung am effektivsten).

Die Vorbereitung erfolgte analog zur regulären PCR (s.u.), als Template wurde cDNA aus unstimulierten CPC verwendet.

\section{Sequenzierung der PCR-Produkte}

Zuletzt mussten die bei der mit idealer Annealing-Temperatur durchgeführten Amplifikation entstandenen DNA-Sequenzen der neuen Primer sequenziert werden, um zu überprüfen, ob mithilfe der Primer tatsächlich die theoretisch erwarteten Produkte synthetisiert worden waren. Hierzu wurden die PCR-Produkte an Sequence Laboratories Göttingen GmbH (Göttingen, Deutschland) gesandt und die dort ermittelte Basenabfolge mittels BLAST (s.o.) überprüft. War mit den Primern die Amplifizierung der gesuchten DNASequenz möglich, so konnten sie für die Polymerasekettenreaktion eingesetzt werden.

\section{Semi-quantitative Real-Time-Polymerasekettenreaktion (q-PCR)}

Zunächst wurde für jedes zu untersuchende Gen ein Mastermix vorbereitet. Der Primer Mix beinhaltet sowohl den Vorwärts- als auch den Rückwärtsprimer des jeweiligen Gens. Der SYBR-Green Mix enthält neben dem interkalierenden Farbstoff auch $\mathrm{MgCl}_{2}$, einen dNTP-Mix und die (taq-)Polymerase.

\section{Mastermix \\ $2 \mu \mathrm{L} \quad$ RNAse freies Wasser \\ $2 \mu \mathrm{L}$ Primer Mix \\ $2 \mu \mathrm{L} \quad$ SYBR-Green Mix}

Dieser Mastermix wurde daraufhin in ein Well einer 96-Well-Platte (Hersteller) pipettiert und danach $1 \mu \mathrm{L}$ der zu untersuchenden cDNA zugefügt. Pro zu untersuchender Probe 
wurden drei Versuchsdurchläufe mit je einem Probentriplett durchgeführt. Es wurde stets auf Eis gearbeitet und nach erfolgter Pipettierung wurden die Wells mittels Optical Flat Cap (Hersteller) verschlossen und die Platte kurz zentrifugiert.

Das Erhitzen bzw. Herunterkühlen der Proben übernahm ein Mastercycle realplex S (eppendorf AG, Hamburg, Deutschland) nach folgendem Schema:

Tabelle 2.3: Protokoll eines PCR-Laufs

\begin{tabular}{|c|c|c|}
\hline Initiale Denaturierung & $2 \mathrm{~min}$ & $95^{\circ} \mathrm{C}$ \\
\hline Denaturierung & $15 \mathrm{sec}$ & $95^{\circ} \mathrm{C}$ \\
\hline Hybridisierung (Annealing) & $15 \mathrm{sec}$ & Spezifische Temperatur \\
\hline Extension & $15 \mathrm{sec}$ & $72^{\circ} \mathrm{C}$ \\
\hline Denaturierung & $15 \mathrm{sec}$ & $95^{\circ} \mathrm{C}$ \\
\hline Schmelzkurve & $\mathrm{x} \cdot 15 \mathrm{sec}$ & Aufsteigend um $0.2^{\circ} \mathrm{C}$ bis $95{ }^{\circ} \mathrm{C}$ \\
\hline
\end{tabular}

Der nach Ablauf der 40 Zyklen ermittelte Ct-Wert für die Probe ging in die statistische Auswertung ein.

\section{Statistik}

Für jede Probe waren pro PCR-Durchlauf drei Ansätze pipettiert worden und aus den erhaltenen Ct-Werten wurde der Mittelwert gebildet. Die Standardabweichung von diesem Mittelwert betrug < 0.5 Ct-Punkte.

Für jede Probe wurden an verschiedenen Tagen drei PCR-Durchläufe durchgeführt und aus den jeweiligen Mittelwerten wurde wiederum der Mittelwert gebildet und die Standardabweichung errechnet. Diese war auch hier $<0.5$ Ct-Punkte.

Die Normalisierung (nach Pfaffl 2001) der PCR-Daten erfolgte in den Hormonversuchen gegen die cDNA der nicht stimulierten Kontrollgruppe und für den Nachweis der Aromatase gegen Progenitorzellen aus Knorpelgewebe von Patienten mit rheumatoider Arthritis (RA).

Als Referenzgen wurde jenes für die Expression der Hypoxanthin-PhosphoribosylTransferase 1 (im Folgenden HPRT-1 genannt) verwantwortliche Gen ausgewählt, da HPRT-1 stets - auch unbeeinflusst von Hormozugabe - identisch exprimiert wurde.

Um die Effizienz E der PCR zu bestimmen, wurde exemplarisch für das HousekeepingGen eine Standardverdünnungsreihe der cDNA $(20 \mathrm{ng} / \mu \mathrm{L}-2 \mathrm{ng} / \mu \mathrm{L}-0.2 \mathrm{ng} / \mu \mathrm{L}-$ 
$0.02 \mathrm{ng} / \mu \mathrm{L}$ ) erstellt und die ermittelten Ct-Werte halblogarithmisch gegen die eingesetzte Menge an cDNA aufgetragen. Aus der Steigung der Standardkurve ließ sich wie folgt die Effizienz der PCR berechnen.

$$
\mathrm{E}=10^{(-1 / \text { Steigung })}
$$

Es ergab sich eine Effizienz E = 1.98 der Referenzprobe, woraufhin als Effizienz 2 angenommen wurde und sich folgende Formel für die Berechnung der Ratio ergab:

$$
\mathrm{R}=2^{\Delta \Delta C t}
$$

Eine Ratio von 2 bedeutete demnach, dass das Zielgen in der Probe doppelt so häufig exprimiert worden ist wie im Kontrollprobenmaterial.

Mittels t-Test für ungepaarte Gruppen sowie Wilcoxon-Whitney-Mann-Test wurden die einzelnen Proben auf statistisch signifikante Unterschiede getestet. 


\subsection{Natriumdodecylsulfat- Polyacrylamidgelelektrophorese (SDS-PAGE) und Western Blot}

\subsubsection{Allgemeines}

Western Blot ist ein Verfahren zum Nachweis von Proteinen, bei dem mittels vorheriger Gelektrophorese (SDS-PAGE) die Proteine zunächst nach ihrer molekularen Masse aufgetrennt werden und daraufhin durch Übertragung auf eine Membran (Blotting) und anschließender Immunreaktion spezifisch bestimmt werden.

Ein Proteingemisch wird zunächst auf ein Polyacrylamidgel mit SDS-Zusatz gegeben und es wird ein elektrisches Feld angelegt. SDS bindet an die Proteine und überlagert deren Eigenladungen, weshalb die Mobilität der Proteine nur abhängig ist von deren molekularen Masse und der zugegebenen Acrylamid-Konzentration, dessen Polymere die Durchlässigkeit des Gels bedingen.

An das Polyacrylamidgel, welches die aufgetrennten Proteine enthält, wird nun in einem zweiten Schritt ein weiteres senkrecht zur Laufrichtung der Gelelektrophorese gerichtetes elektrisches Feld angelegt. Die Proteine wandern nun aus dem Gel auf eine installierte Membran aus Polyvinylidenfluorid (PVDF) (Blotting).

Die nach ihrer Größe aufgetrennten und auf eine Membran geblotteten Proteine können nun mittels Coomassie-Blau eingefärbt werden. Durch vorherige Zugabe eines Proteinmarkergemisches, welches Proteine bekannter Größe enthält, kann über einen Vergleich mit selbigem die Proteingröße bestimmt werden.

Für den spezifischen Nachweis der Proteine folgt auf das Blotting eine Immunreaktion mit Antikörpern. Hierzu wird ein monoklonaler Antikörper auf die PVDF-Membran aufgetragen, welcher spezifisch an ein Epitop des gewünschten Proteins bindet. In diesem Fall wurde ein Antikörper benutzt, der aus B-Lymphozyten einer Maus hergestellt wurde und gegen ein Epitop des Aromataseenzyms gerichtet ist. In einem nächsten Schritt wird ein sekundärer Antikörper hinzugegeben, welcher an die Fc-Region des primären Antikörpers bindet und mit einer Meerrettichperoxidase (HRP, horseradish peroxidase) gekoppelt ist. Dieses Enzym katalysiert eine Chemilumineszenzreaktion, die unter Umsetzung eines Substrates (hier: Lumigen PS-3-ECL Plus Detection System von Amersham) Licht emittiert, welches mittels Röntgenfilmkassette detektiert werden kann. 


\title{
2.6.2 Durchführung
}

\section{Gelektrophorese}

Zunächst wurden die Polyacrylamidgele wie folgt hergestellt: In eine aus zwei mit Ethanol gereinigten Glasplatten bestehende Form wurde das Trenngel etwa $6 \mathrm{~cm}$ hoch gegossen. Bei einer erwarteten atomaren Masse des gesuchten Aromataseenzyms von $55 \mathrm{kD}$ hat sich eine Acrylamidkonzentration von $10 \%$ als geeignet erwiesen, um eine optimale Laufstrecke bis etwa zur Mitte des Trenngels zu erreichen.

\section{Trenngel (10\% Acrylamid)}

$1.40 \mathrm{~mL}$ Trenngelpuffer (1.5 M Trisaminomethan (TRIS), $\mathrm{pH} 8.9$ )

$55 \mu \mathrm{L} \quad \operatorname{SDS}(10 \%)$

$1.85 \mathrm{~mL}$ Acrylamid

$2.00 \mathrm{~mL}$ dest. Wasser

$5 \mu \mathrm{L} \quad$ TEMED

$0.25 \mathrm{~mL} \quad 10 \%$ APS

Alle Reagenzien wurden vermischt und daraufhin der Radikalstarter Ammoniumperoxodisulfat (APS) hinzugegeben, woraufhin die Polymerisation des Gels begann. Nach Aushärten des Trenngels (15 min) konnte das Sammelgel auf das Trenngel gegossen werden. Zudem wurde ein Kamm aus Plastik eingesetzt, welcher nach dem Aushärten des Gels entfernt wurde und zur Formung von Taschen zur Auftragung der Proteingemische diente.

\section{Sammelgel}

\author{
$1.25 \mathrm{~mL}$ Sammelgelpuffer (0.5 M TRIS, pH 6.8) \\ $50 \mu \mathrm{L} \quad \operatorname{SDS}(10 \%)$ \\ $0.80 \mathrm{~mL}$ Acrylamid \\ $2.70 \mathrm{~mL}$ dest. Wasser \\ $5 \mu \mathrm{L} \quad$ TEMED \\ $0.20 \mathrm{~mL} \quad 10 \%$ APS
}

Das fertige Gel wurde mit der Form in die Gelektrophoresekammer installiert. Anschließend wurden die zwei Gelelektrophoresetanks mit Laufpuffer befüllt, so dass die 
Probentaschen des Sammelgels nach Entfernen des Kamms mit selbigem gefüllt waren.

\title{
Laufpuffer
}

\author{
$30.30 \mathrm{~g}$ TRIS $(0.25 \mathrm{M})$ \\ $142.60 \mathrm{~g}$ Glycin $(1.9 \mathrm{M})$ \\ $50 \mathrm{~mL}$ SDS $(10 \%)$ \\ $950 \mathrm{~mL}$ dest. Wasser
}

Danach wurden die in (2.2) erhaltenen Zellpellets in einem Gemisch aus SDSProbenpuffer und $\beta$-Mercaptoethanol (Verhältnis 9:1) für 5 min bei $95^{\circ} \mathrm{C}$ denaturiert. $\beta$-Mercaptoethanol diente hierbei zur Spaltung von Disulfidbrïcken. Jedes Zellpellet $\left(1.8 \cdot 10^{5}\right.$ Zellen) wurde in $25 \mu \mathrm{L}$ des Probenpuffers suspendiert. In die mit Laufpuffer gefüllten Geltaschen wurden nun die Proben aufgetragen. Eine Geltasche wurde mit dem oben genannten Proteinmarker als Referenz beladen.

\section{SDS-Probenpuffer}

\author{
$0.30 \mathrm{M}$ TRIS \\ $9 \%$ SDS \\ $22.50 \%$ Glycerin \\ Spatelspitze Bromphenolblau
}

Ein nun angelegtes elektrisches Feld mit einer Stromstärke von 10-15 mA konzentrierte die Proteingemische innerhalb des Sammelgels auf Höhe der Trenngelkante nach etwa 45 min. Die Erhöhung der Stromstärke auf 20-25 mA ermöglichte das Wandern der Proteine innerhalb des Trenngels, nach etwa 2-3 h hatten sich die Proteine innerhalb des Gels aufgetrennt.

\section{Blotting auf eine PVDF-Membran}

Das Blotting auf die PVDF-Membran erfolgte in einem mit Transferpuffer gefüllten Tank. Das Gel wurde hierzu direkt auf die zuvor kurz mit $100 \%$ Methanol getränkte Membran positioniert. Drei in Transferpuffer eingelegte Filterpapiere auf der Seite der Membran sowie jeweils ein mit Puffer getränkter Schwamm auf jeder Seite dienten 
als Abstandshalter zu einer Metallkassette, die mit leichtem Druck Membran und Gel in Position hielt. Die Metallkassette wurde daraufhin in den Tank installiert und ein elektrisches Feld mit $350 \mathrm{~mA}$ angelegt (Anode auf der Seite der Membran). Nach etwa 90 min waren die Proteine vom Gel auf die Membran gewandert.

\section{Transferpuffer}

$$
\begin{array}{cl}
6.05 \mathrm{~g} & \text { TRIS }(25 \mathrm{~mm}) \\
28.80 \mathrm{~g} & \text { Glycin }(192 \mathrm{mM}) \\
400 \mathrm{~mL} & \text { Methanol }(100 \%)
\end{array}
$$

Zur Überprüfung des erfolgreichen Blottings konnten die Proteine auf der PVDFMembran mittels Coomassie-Blau eingefärbt werden. Hierzu wurde die Membran für zwei Minuten in der Färbelösung unter Schwenken gefärbt und danach die unspezifischen Färbungen mittels Entfärber I (2-5 min) und Entfärber II (2-5 min) entfernt.

\section{Färbelösung}

$0.10 \mathrm{~g}$ Coomassie Brilliant Blue $(0,1 \%)$

$50 \mathrm{~mL}$ Methanol (50\%)

$7 \mathrm{~mL}$ Essigsäure (7\%)

\section{Entfärber 1}

$50 \mathrm{~mL}$ Methanol (50\%)

$7 \mathrm{~mL}$ Essigsäure (7\%)

\section{Entfärber 2}

$90 \mathrm{~mL}$ Methanol (90\%)

$10 \mathrm{~mL}$ Essigsäure (10\%)

\section{Immunreaktion}

Für die nun anschließende Immunreaktion musste die Membran zunächst für zwei Stunden bei Raumtemperatur in einer Blocklösung aus Milchpulver (5\%) und TBS-T 
inkubiert werden, um unspezifische Proteinbindungsstellen zu blocken. Anschließend wurde der primäre Antikörper in obiger Blocklösung in einer Verdünnung von 1:250 suspendiert und die Membran bei $4{ }^{\circ} \mathrm{C}$ unter Schwenken über Nacht inkubiert. Hierfür wurde ein Antikörper (Mouse anti human cytochrome P450 Aromatase. AbD Serotec, Oxford, UK) benutzt, der aus B-Lymphozyten einer Maus hergestellt wurde und gegen ein Epitop des Aromataseenzyms gerichtet ist.

Eine andere Membran, deren Proteine als Negativkontrolle fungierten, wurde statt des Primärantikörpers lediglich mit der Blocklösung über Nacht inkubiert.

\section{Tris-Buffered Saline (TBS) mit Tween - Lösung (TBS-T)}

$100 \mathrm{~mL}$ TBS

$0.50 \mathrm{~g}$ Tween $20(0.05 \%)$

$900 \mathrm{~mL}$ dest. Wasser

\section{Tris-Buffered Saline (TBS), pH 7.4}

\section{$24.20 \mathrm{~g}$ Tris}

$87.60 \mathrm{~g} \mathrm{NaCl}$

$1000 \mathrm{~mL}$ dest. Wasser

Daraufhin wurde die Membran fünf Mal für 5 min in TBS-T gewaschen und danach mit dem gegen den primären Antikörper gerichteten Sekundärantikörper (Anti-Mouse IgG Peroxidase (Sigma A9917)) mit einer Verdünnung von 1:40000 in obiger Blocklösung für eine Stunde bei Raumtemperatur unter Schwenken inkubiert. Nach einem weiteren Waschschritt wurde das Substrat (ECL Plus Detection System, Amersham) für die Peroxidase des sekundären Antikörpers hinzugegeben und für 5 min inkubiert. Hierzu wurde nach Angaben des Herstellers verfahren. Das emittierte Licht der Chemiluminiszenzreaktion konnte danach auf einem Röntgenfilm (Amersham Hyperfilm) festgehalten werden. Nach 30 min Belichtungszeit in einer lichtdichten Röntgenkassette und Entwicklung in einer Entwickler- und einer Fixierlösung konnte der Röntgenfilm eingescannt werden. 


\section{Ergebnisse}

Dieses Kapitel ist in drei Teile gegliedert. Der erste Teil behandelt den Nachweis der Aromatase in Kniegelenksgewebe und in chondrogenen Progenitorzellen mittels unterschiedlicher Methoden und beleuchtet geschlechts-, alters- und BMI-spezifische Aspekte in der Ausbildung des Enzyms. Im zweiten Teil finden sich die Ergebnisse des AromataseHemmtests. Der letzte Teil fasst alle Ergebnisse zusammen.

\subsection{Nachweis von Aromatase in Knorpelgewebe und chondrogenen Progenitorzellen auf Protein- und mRNA-Ebene}

Im Rahmen dieser Arbeit wurde zunächst untersucht, ob das Enzym Aromatase von Zellen des Kniegelenkes in späten Stadien der Arthrose exprimiert wird und ob auch die aus dem Knochenmark in die defekten Areale migrierenden chondrogenen Progenitorzellen die Fähigkeit zur lokalen Östrogensynthese über Aromatisierung besitzen. Hierzu wurden initial immunhistochemische Untersuchungen an Knorpelgewebe von Patienten mit OA durchgeführt. Daraufhin galt es zu beweisen, dass auch CPC das Enzym synthetisieren. Dazu gelang der Nachweis mittels Immunhistochemie an in Alginat kultivierten Zellen sowie mittels Western Blot an in 2D-Kultur vermehrten CPC. Dass die Transkription des Aromatasegens, also die Erstellung von mRNA-Kopien der DNA, in den CPC abläuft, konnte durch die semiquantitative Polymerasekettenreaktion bestätigt werden.

\subsubsection{Immunhistochemischer Nachweis von Aromatase in Knorpelgewebe und in Alginat kultivierten CPC}

Es wurden, wie in Kapitel 2.4 erläutert, immunhistochemische Bilder von Knorpelgewebe von vier Patienten mit OA sowie von in Alginat kultivierten CPC von zwei Patienten angefertigt. Über eine Antikörperreaktion wurde hier spezifisch das Aromataseenzym mit einem roten Farbstoff markiert. 


\section{Aromatase in Kniegelenksgewebe in späten Stadien der Arthrose}

Auf den immunhistochemisch gefärbten Gewebeschnitten von Kniegelenksknorpel und subchondralem Knochen (siehe Abbildung 3.1) zeigten sich typische histopathologische Merkmale der mittleren und späten Osteoarthritis (vgl. Sulzbacher 2000, Pritzker et al. 2006) wie Fissuren der Knorpeloberfläche und tiefe, bis zum subchondralen Knochen reichende, Risse, eine duplizierte Tidemark, welche teilweise durch aus dem Markraum einsprießende Gefäße unterbrochen war, und zu sogenannten Zellclustern (Zellnestern, Brutnestern) aggregierte Chondrozyten.

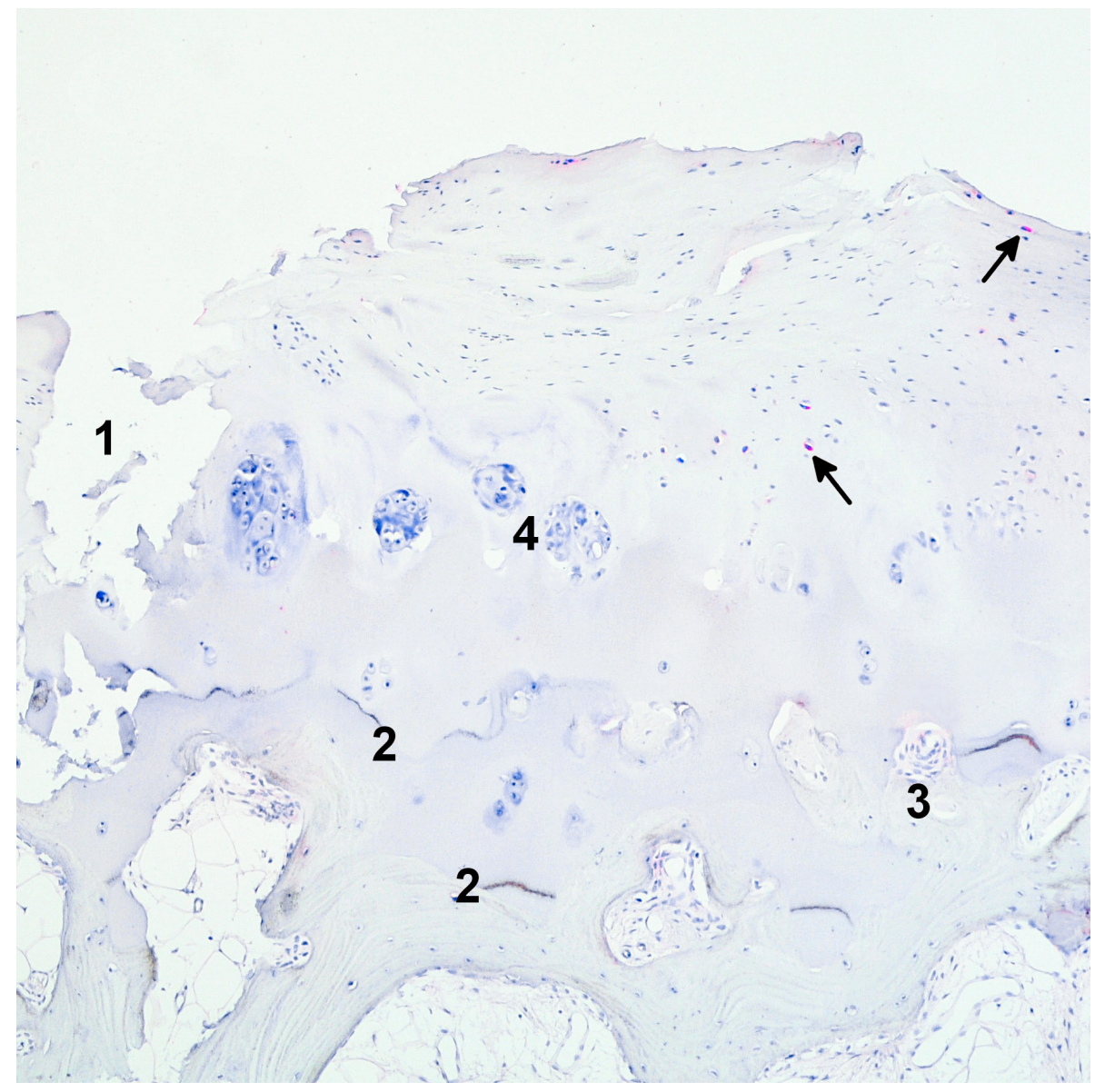

Abbildung 3.1: Immunhistochemische Detektion von Aromatase in arthrotischem Knorpel. Zehnfache Vergrößerung, Gegenfärbung mit Hämalaun. Der Knorpel zeigt bis zum subchondralen Knochen reichende Risse und Fissuren (1), Unterbrechungen der duplizierten (2) Tidemark, aus dem Markraum einsprießende Gefäße (3) und zu Zell- oder Brutnestern aggregierte Chondrozyten (4). Es finden sich rot markierte, für Aromatase postive Zellen (Pfeile) in der Tangentialfaser- und der Übergangszone, in der es zu Zellproliferationen gekommen ist. 
In dieser Umgebung fanden sich für Aromatase positive Zellen vor allem in der Tangentialfaserzone und der Übergangszone des Knorpels sowie im fibrokartilaginären Ersatzgewebe, also vor allem dort, wo es reaktiv zunächst zu einer Hyperproliferation von Zellen im Sinne eines Reparationsversuches gekommen war.

Abbildung 3.2 zeigt für Aromatase positive Zellen (Pfeile) in der Übergangszone des hyalinen Knorpels. Die Übergangszone ist verschmälert und es werden Arrosionen an der Knorpeloberfläche sichtbar.

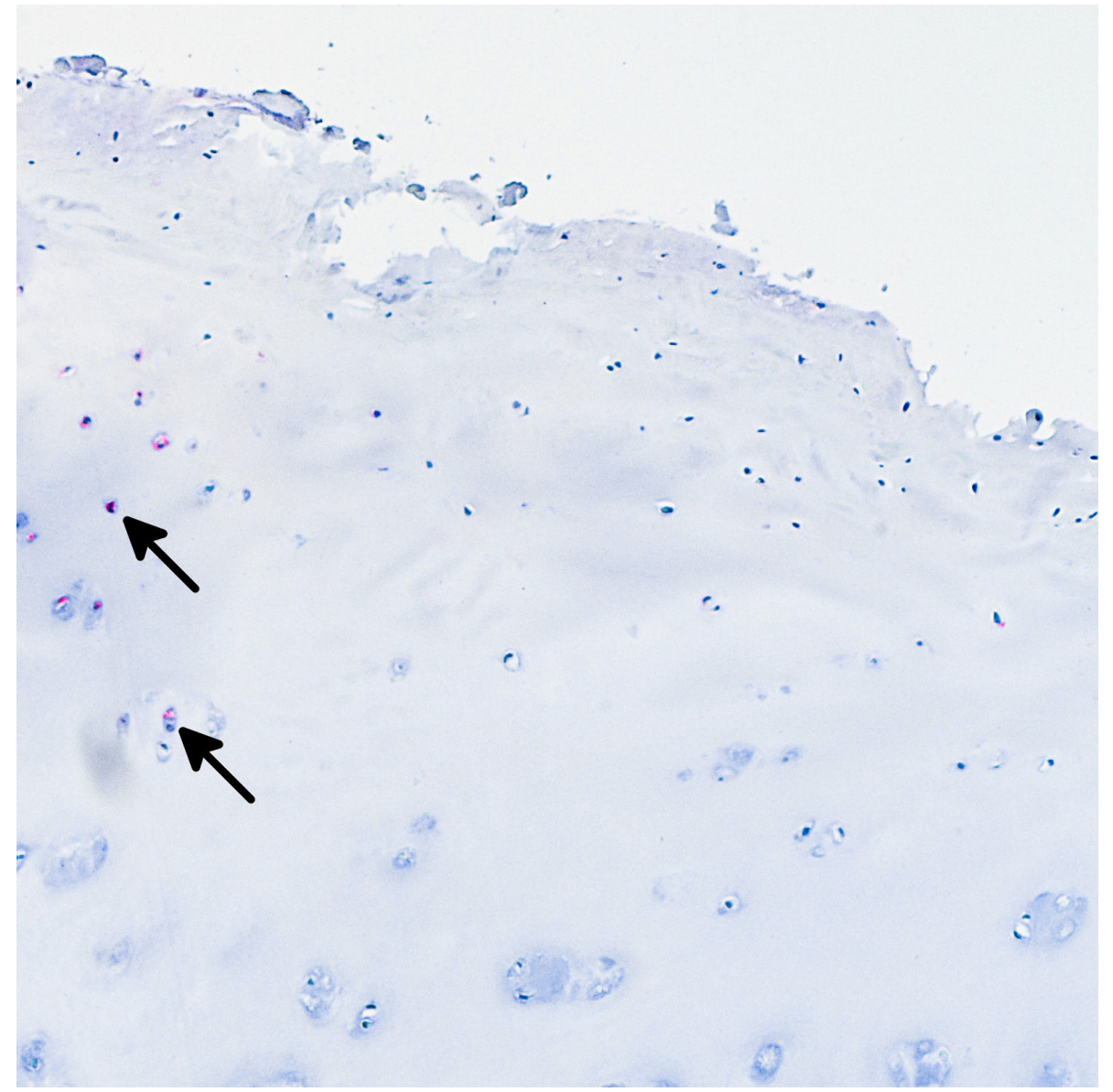

Abbildung 3.2: Aromatase exprimierende Zellen in der Übergangszone des arthrotischen Knorpels. Zehnfache Vergrößerung, Gegenfärbung mit Hämalaun. Es finden sich in der Übergangszone rot markierte Zellen, die die Aromatase exprimierten (Pfeile). 
Bei genauerer Betrachtung (siehe Abbildung 3.3 ist zu erkennen, dass intrazelluläre, zytoplasmatische Bereiche der Aromatase exprimierenden Zellen angefärbt wurden.

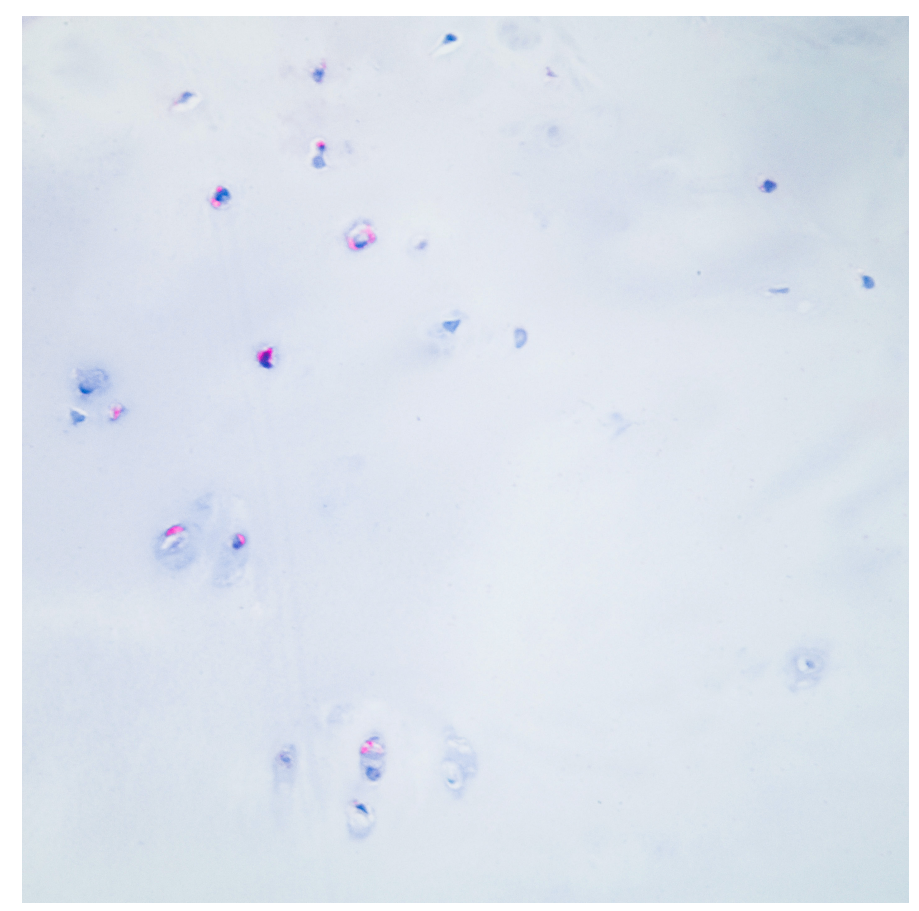

Abbildung 3.3: Für Aromatase positive Zellen in hyalinem Knorpel in der OA. 60-fache Vergrößerung, Gegenfärbung mit Hämalaun. Es zeigt sich eine intrazelluläre, zytoplasmatische Positivität (rot markiert) bei einigen Zellen des hyalinen Knorpels.

Neben den positiven Zellen in der Übergangs- und Tangentialfaserzone fanden sich auch Aromatase exprimierende Zellen in dem fibrokartilaginären Reparaturgewebe, welches bei schweren Defekten, die bis an den subchondralen Knochen reichen, den hyalinen Knorpel narbig ersetzt und in Zusammensetzung der Extrazellulärmatrix und in seinen biomechanischen Eigenschaften am ehesten dem Faserknorpel ähnelt. Abbildung 3.4 zeigt intrazelluläre, zytoplasmatische Markierungen von Zellen in diesem Gewebe. Hier sind gut die kollagenen Faserbündel, welche in diesem Fall vor allem aus Kollagen 1 bestehen, zu erkennen. In gesundem hyalinen Knorpel sind die Faserbündel hingegen aufgrund ähnlicher lichtbrechender Eigenschaften von Kollagenen und dem Rest der EZM lichtmikroskopisch nicht sichtbar, sie sind maskiert.

In den bei jeder Färbung durchgeführten Negativkontrollen zeigten sich keine Farbreaktionen, wodurch unspezifische Markierungen von Proteinen ausgeschlossen werden konnten (siehe Abbildung 3.5. 


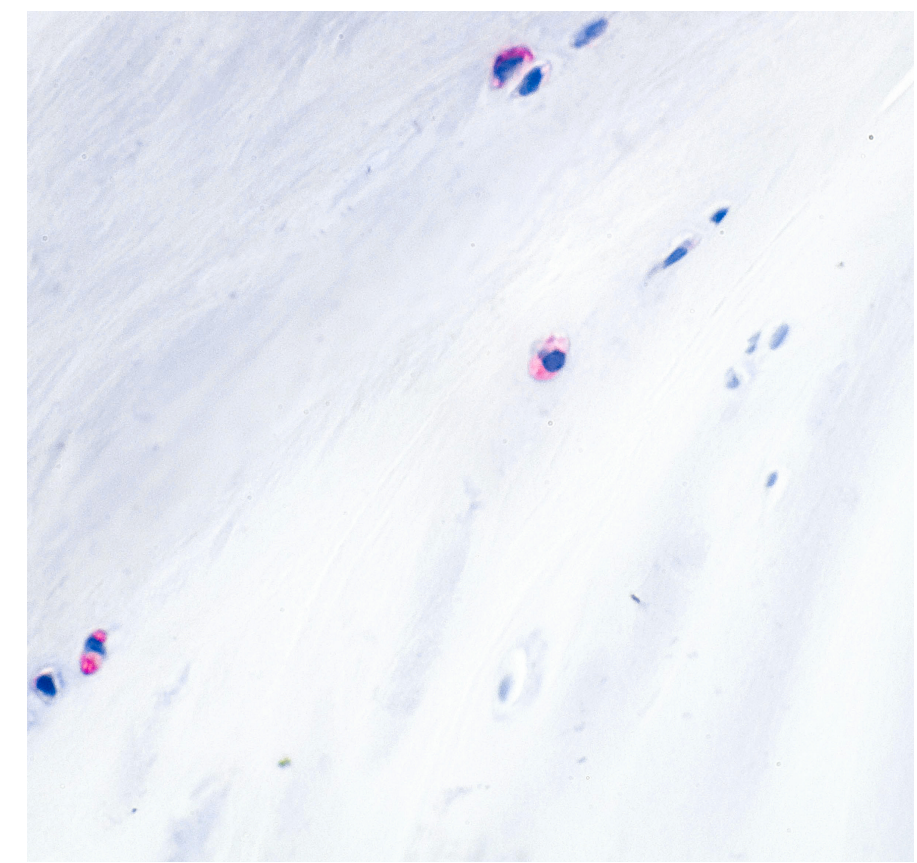

Abbildung 3.4: Für Aromatase positive Zellen in fibrokartilaginärem Reparaturgewebe. Ausschnitt bei 60-facher Vergrößerung, Gegenfärbung mit Hämalaun. Das Reparaturgewebe ist an den sichtbaren Kollagenfasern zu erkennen. In dieser Umgebung fanden sich Aromatase exprimierende Zellen (rot markiert), es wurden zytoplasmatische Bereiche angefärbt.

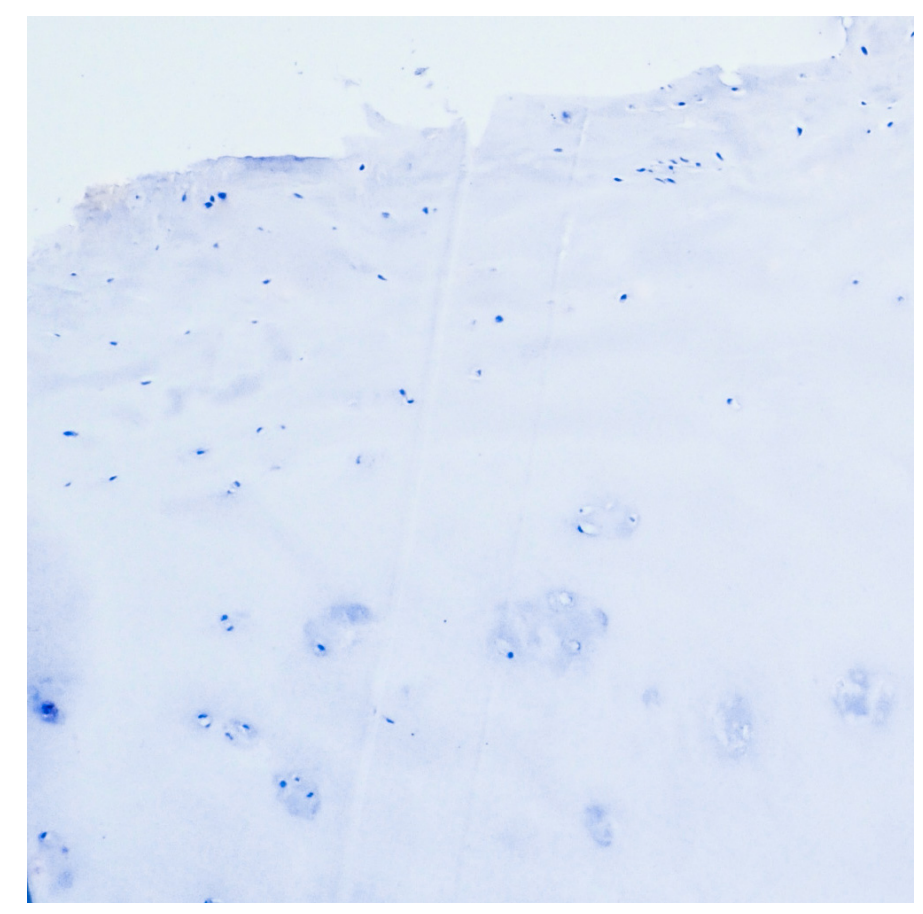

Abbildung 3.5: Negativkontrolle. Ausschnitt bei zehnfacher Vergrößerung, Färbung mit Hämalaun. Durch bei jeder Färbung durchgeführte Negativkontrollen konnten unspezifische Markierungen von Proteinen ausgeschlossen werden. 


\title{
In Alginat kultivierte chondrogene Progenitorzellen exprimieren Aromatase
}

Nachdem die in Alginat kultivierten CPC, wie unter Kapitel 2.3.2 beschrieben, vorbereitet und anschließend immunhistochemisch gefärbt worden waren, konnte bei einigen Zellen das Aromatase-Enzym nachgewiesen werden (siehe Abbildung 3.6). Aufgrund einer ausgeprägten Basophilie des Alginats und daraus resultierender übermäßig starker Anfärbung mit der Folge einer schlechteren Beurteilbarkeit der Alginatschnitte wurde hier auf eine Gegenfärbung verzichtet. Abbildung 3.6 zeigt eine Bildmontage und stellt eine Alginatkugel mit darin kultivierten CPC dar, so wie sie unter einem Durchlichtmikroskop erkennbar wird. Sie stellt eine Alginatkugel vor der Fixierung und immunhistochemischen Prozessierung dar. Die quadratische Abbildung in der rechten unteren Ecke stellt einen Ausschnitt aus der Alginatkugel dar, nachdem die Kugel fixiert und eine immunhistochemische Färbung durchgeführt worden ist. Es zeigten sich für Aromatase positive chondrogene Progenitorzellen, die aufgrund des Einbettungsprozesses in ihre ursprüngliche Form verloren haben und teilweise zerstört worden sind.

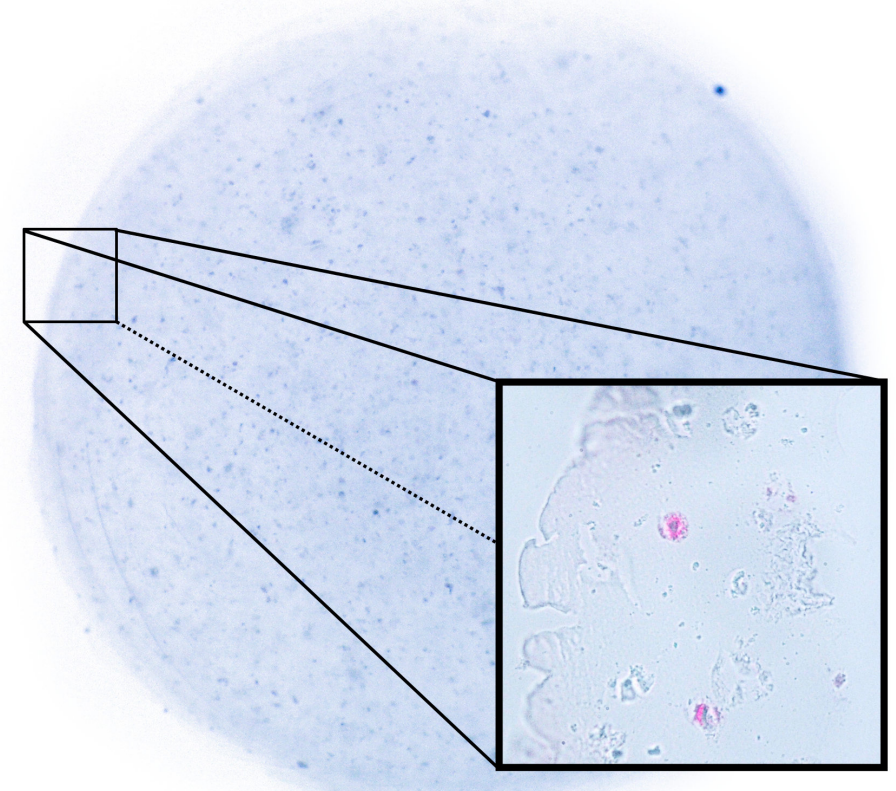

\begin{abstract}
Abbildung 3.6: Alginatkugel mit einem Ausschnitt bei stärkerer Vergrößerung. Die Abbildung zeigt eine Bildmontage einer Alginatkugel mit darin kultivierten CPC bei achtfacher Vergrößerung. Die Abbildung rechts unten zeigt einen Bildausschnitt aus einer 60-fachen Vergrößerung aus der Alginatkugel, nachdem diese fixiert, geschnitten und immunhistochemisch aufbereitet worden ist. Es zeigten sich, bei unterlassener Gegenfärbung, für Aromatase positive CPC (rot markiert).
\end{abstract}




\subsubsection{Nachweis von Aromatase in CPC mittels Western Blot}

Ein weiterer Nachweis des Vorhandenseins der Aromatase in den chondrogenen Vorläuferzellen auf Proteinebene geschah mittels Western Blot. Hierzu wurden zunächst CPC aus Knorpelproben von sechs Patienten (drei Frauen, drei Männer) gewonnen und in Kulturflaschen vermehrt.

Die erfolgreiche Auftrennung der Proteine nach ihrer molekularen Masse und der anschließende Transfer (Blotting) auf eine PVDF-Membran konnte mittels Proteinfärbung durch Coomassie-Blau nachgewiesen werden und wird in Abbildung 3.7 gezeigt. Auf der linken Seite ist das Proteinmarkergemisch aus Proteinen mit bekannten

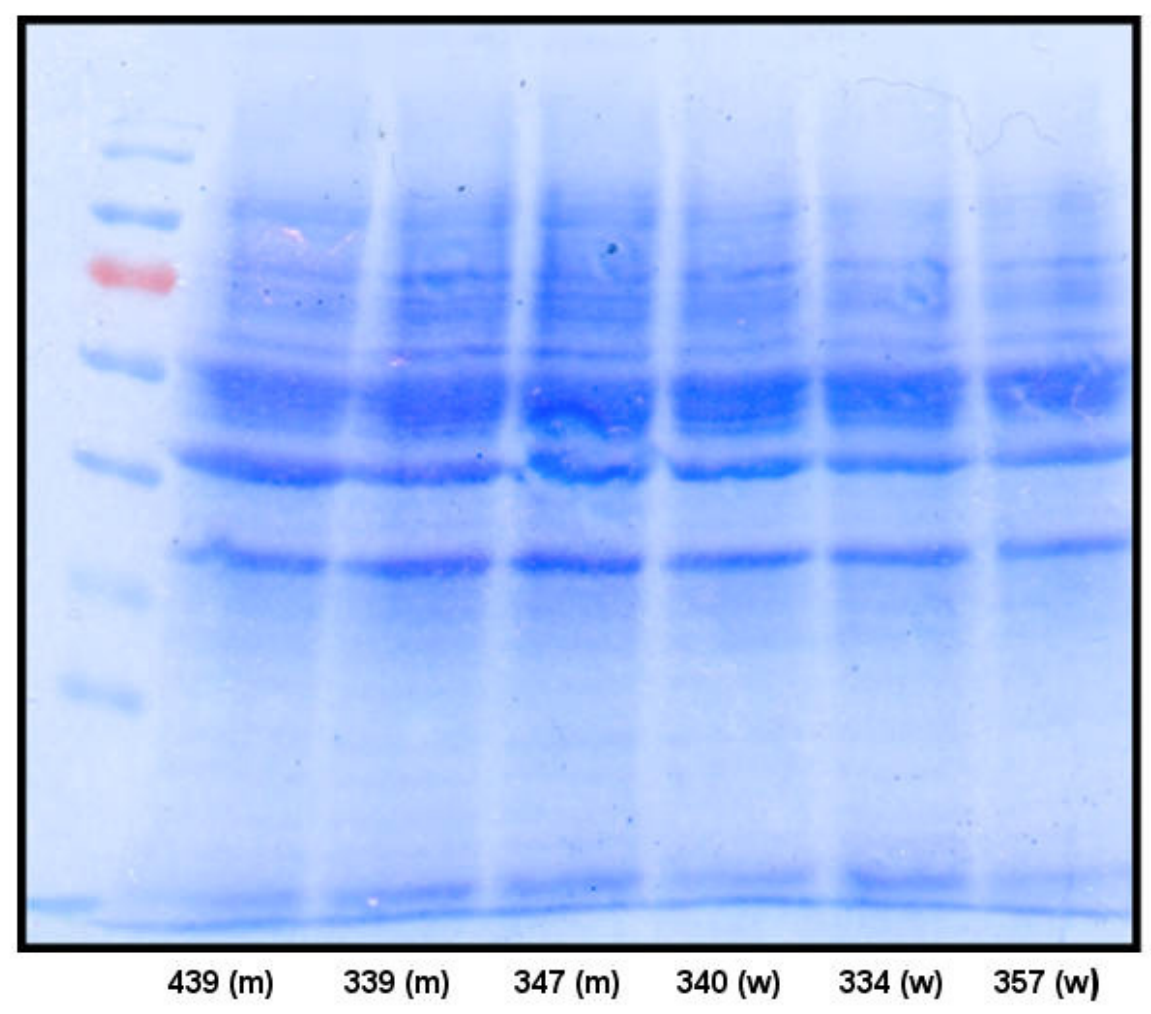

Abbildung 3.7: Coomassie-Blau-Färbung der PVDF-Membran. Nach ihrer atomaren Masse aufgetrennte und auf eine PVDF-Membran geblottete Proteine aus chondrogenen Progenitorzellen sechs verschiedener Patienten. Links: Proteinmarkergemisch. Unten: Probennummern mit Angabe des Geschlechts ( $w=$ weiblich; $m=$ männlich).

atomaren Massen zu erkennen. Über einen Vergleich der Proben mit selbigem ist eine Massenbestimmung möglich. Man erkennt die sechs nebeneinander in Probentaschen aufgetragenen Patientenproben. Die Nummern der Patienten sind Teil eines internen Probenarchivs der AG Orale Biologie und Geweberegeneration, Abteilung Zahnärztliche 
Prothetik, Universitätsmedizin Göttingen. In den Klammern hinter den Probennummern wird Auskunft über das Geschlecht gegeben.

In der anschließenden Immunreaktion wurde spezifisch durch Antikörperbindung das gesuchte Protein auf der PVDF-Membran nachgewiesen (Siehe Abbildung 3.8.

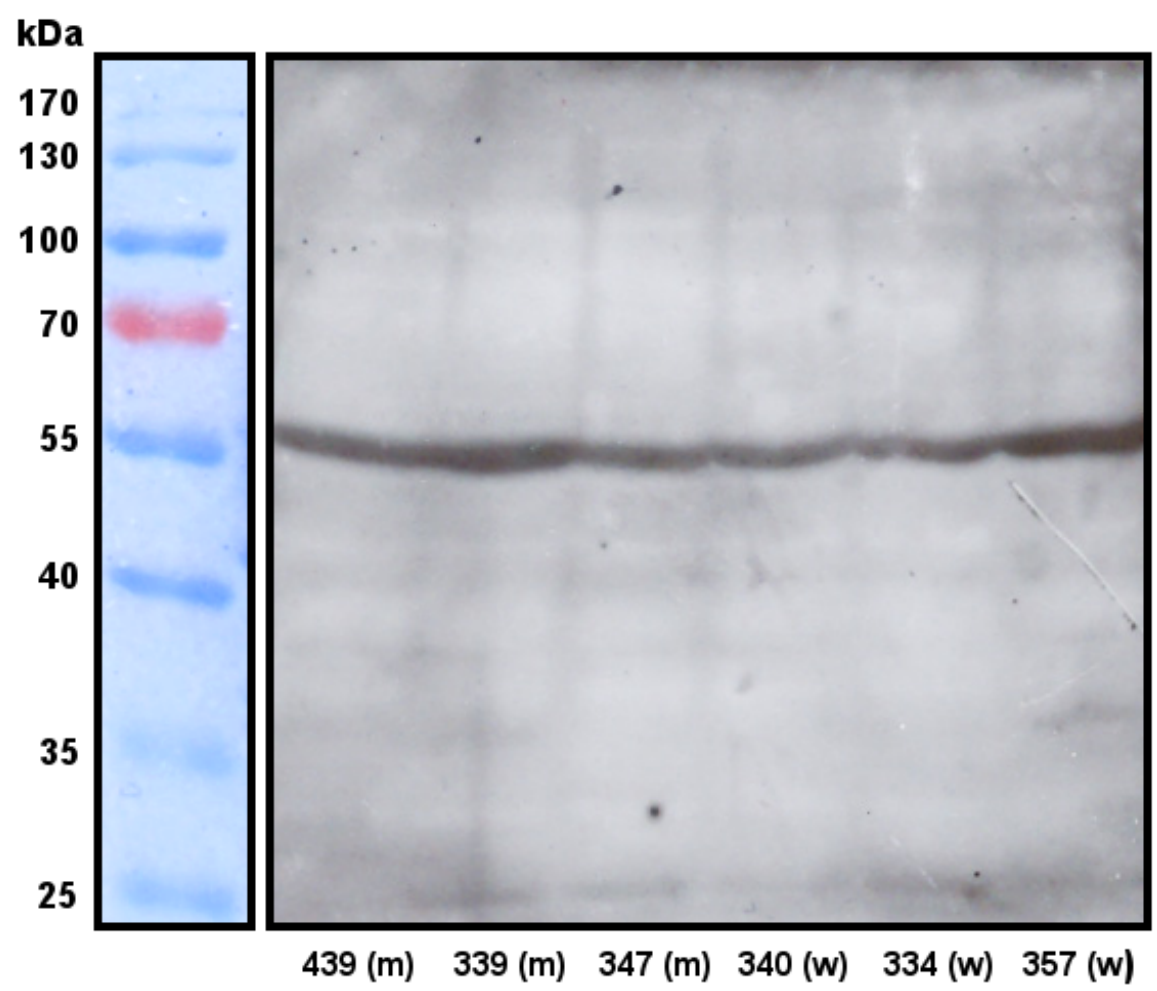

\begin{abstract}
Abbildung 3.8: Antikörperreaktion gegen Aromatase bei CPC von sechs Patienten. Antikörperverdünnung 1:250, Belichtungszeit: $40 \mathrm{~min}$. Positives Signal oberhalb einer molaren Masse von $55 \mathrm{kDa}$ bei allen sechs Proben nach Inkubation mit einem Aromatase-Antikörper und anschließender Chemilumineszenzreaktion. Links: Proteinmarkergemisch mit bekannten atomaren Massen in kDa. Unten: Probennummern mit Angabe des Geschlechts ( $w=$ weiblich; $m=$ männlich).
\end{abstract}

Auf der linken Seite der Abbildung findet sich das Proteinmarkergemisch (entnommen aus Abbildung 3.7) aus Proteinen mit bekannten atomaren Massen (in kDa). Am Unterrand sind die Patientennummern mit Auskunft über das Geschlecht dargestellt. Schwarze Signale bedeuten eine Belichtung des Röntgenfilms. Die Verdünnung des AromataseAntikörpers in einer Blocklösung aus Milchpulver (5\%) betrug 1:250 und der Röntgenfilm ist für 40 Minuten in einer lichtdichten Röntgenkassette belichtet worden.

In der Immunreaktion zeigte sich bei allen sechs Proben ein positives Signal oberhalb von $55 \mathrm{kDa}$, was mit der bekannten atomaren Masse von $58 \mathrm{kDa}$ (Czajka-Oraniec und 
Simpson 2010) vereinbar war. Hierdurch konnte bestätigt werden, dass die Synthese der Aromatase in den CPC aller Patienten stattgefunden hatte. Ein geschlechtsspezifischer Unterschied war nicht auszumachen.

In den zusätzlich angefertigten Negativkontrollen zeigten sich keine Signale, wodurch unspezifische Markierungen von Proteinen ausgeschlossen werden konnten. 


\subsubsection{Nachweis von Aromatase in CPC auf RNA-Ebene}

Die isolierte mRNA aus in Kulturflaschen vermehrten CPC von Patienten $(n=12)$ wurde in cDNA umgeschrieben und die für die Aromatase kodierende Region amplifiziert. Für jeden Patienten wurden drei PCR-Durchläufe durchgeführt, wobei in jedem Durchlauf drei Proben amplifiziert worden sind. Anschließend wurden die erhaltenen Ct-Werte notiert. Aus jedem Lauf wurde der Ct-Mittelwert der drei Proben berechnet und die Standardabweichung bestimmt, welche in jedem Lauf $<0.5$ Ct-Punkte betrug. Aus den Mittelwerten jedes Laufes wurde wiederum das Mittel bestimmt. Auch hier betrug die Standardabweichung <0.5 Ct-Punkte. Abbildung 3.9 bildet die aus drei Durchläufen an je drei verschiedenen Tagen gemittelten Egebnisse für zwölf Patienten ab.

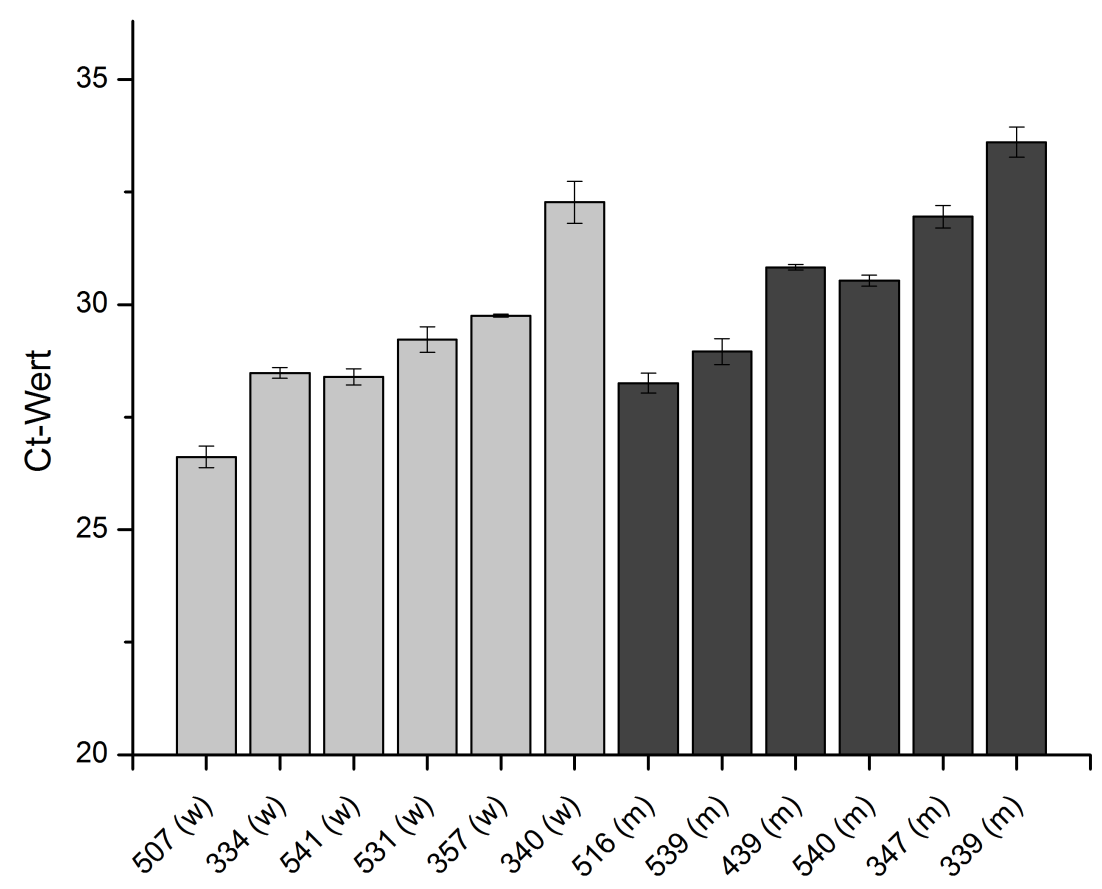

Abbildung 3.9: Aus drei Durchläufen gemittelte Ct-Werte nach Amplifikation von Aromatase-mRNA mittels PCR. Ordinate: Ct-Werte. Abszisse: Probennummern mit Hinweis auf das Geschlecht der Patienten ( $w=$ weiblich; $m=$ männlich). Die Standardabweichungen sind zusätzlich grafisch dargestellt.

Hier sind die Ct-Werte der einzelnen Proben mit der Standardabweichung abgebildet, ein Hinweis hinter der Patientennummer gibt Auskunft über das Geschlecht der Patienten ( $\mathrm{w}=$ weiblich; $\mathrm{m}=$ männlich). Es ist $\mathrm{zu}$ beachten, dass ein niedriger Ct-Wert mit einer großen Ausgangsmenge an cDNA respektive mRNA einhergeht, da in diesem Fall die 
Fluoreszenzschwelle in einem früheren Zyklus erreicht wird.

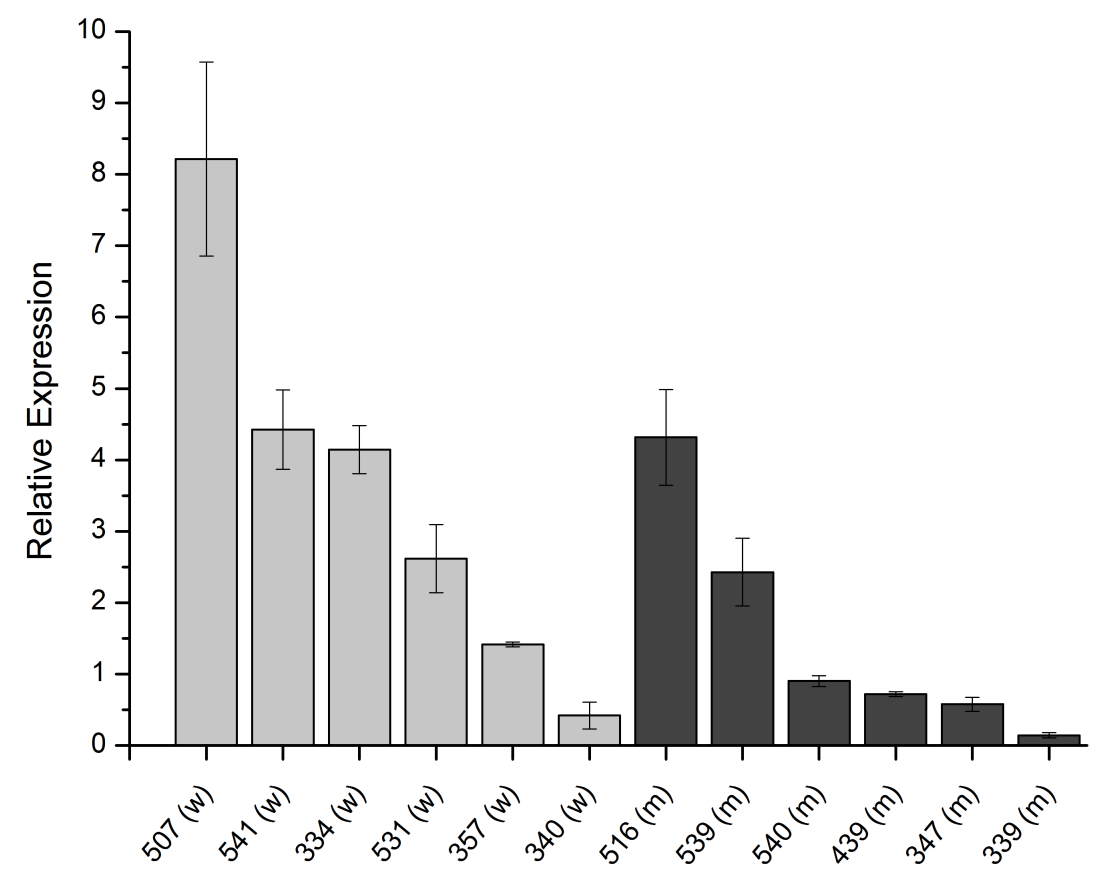

Abbildung 3.10: Relative Expression (Ratio) von Aromatase mRNA in chondrogenen Progenitorzellen. Ordinate: Relative Expression (Ratio). Abszisse: Probennummern mit Hinweis auf das Geschlecht der Patienten ( $w=$ weiblich; $m=$ männlich). Normalisierte Ergebnisse der Amplifikation von Aromatase cDNA aus CPC von zwölf Patienten.

Zur relativen Quantifizierung der so ermittelten PCR-Daten wurden die Ct-Werte nun, wie in Kapitel 2.5.2 beschrieben, auf die Ct-Werte des Housekeeping-Gens HPRT-1 (ebenfalls Mittelwerte aus drei Läufen) bezogen und dann, in diesem Fall des reinen Nachweises von Aromatase-mRNA, gegen Material aus CPC von Patienten mit rheumatoider Arthritis (RA) als Kontrolle normalisiert. Aus diesen Daten konnte dann, nachdem zuvor die Effizienz der Amplifikation der Gene exemplarisch für das Housekeeping-Gen HPRT-1 anhand einer Standardverdünnungsreihe bestimmt worden war, die Ratio nach Pfaffl (Pfaffl 2001) berechnet werden, welche den relativen Expressionsunterschied zwischen Probe und Kontrolle, bezogen auf das Housekeeping-Gen, angibt. In Abbildung 3.10 ist dieser relative Expressionsunterschied für alle zwölf Patienten dargestellt.

Bei Betrachtung der Ergebnisse fiel zunächst auf, dass in jeder Probe zu amplifizierendes Material vorhanden war. Dies bedeutete, dass die chondrogenen Vorläuferzellen aller 
Patienten in der Lage waren, mRNA zu exprimieren, welche als Matrize zur Synthese des Aromatase-Enzyms diente. Weiterhin fiel auf, dass diese Expression in ganz unterschiedlichem Ausmaß stattfand. So war in einigen Proben die vier- oder achtfache Menge an mRNA im Vergleich zum mRNA-Gehalt der Kontrolle $($ Ratio $=1)$ vorhanden. In anderen Proben war dagegen nur ein Teil der in der Kontrollprobe vorhandenen mRNA exprimiert worden.

Zur Detektion von geschlechtsspezifischen Unterschieden in der Expression der Aromatase mRNA wurden der Mittelwert der Ratios der weiblichen Patienten mit denen der männlichen Patienten mittels t-Test für zwei ungepaarte Gruppen verglichen. Hierbei zeigte sich kein signifikanter Unterschied $(\mathrm{p}=0.1)$. 
Neben dem weiblichen Geschlecht ist ein hohes Lebensalter ein weiterer starker Risikofaktor zur Entwicklung einer OA (siehe Kapitel 1.1.1). Das Durchschnittsalter des Patientenkollektivs $(\mathrm{n}=12)$ zum Zeitpunkt der Gewebeentnahme lag bei $68 . \overline{3}$ Jahren, wobei der jüngste Patient 58 Jahre und der älteste Patient 88 Jahre alt war (Standardabweichung, SD: 8.66 Jahre). Da das Durchschnittsalter des Eintretens der Menopause bei 51 Jahren liegt (Grady 2006), konnte man davon ausgehen, dass alle hier eingeschlossenen weiblichen Patienten sich bereits in der Postmenopause befanden.

Aufgrund des gewichtigen Einflusses des Alters auf die Entwicklung einer Arthrose, lag ein Vergleich der Expressionslevel des Aromatasegens mit diesem Risikofaktor auf der Hand. Trug man die Ratios gegen das Alter der Patienten zum Zeitpunkt der Knorpelentnahme auf, wie in Abbildung 3.11 geschehen, so schien eine Kongruenz zwischen höherem Lebensalter und vermehrter Genexpression zu bestehen. Eine eingefügte Trendlinie veranschaulicht diesen Sachverhalt.

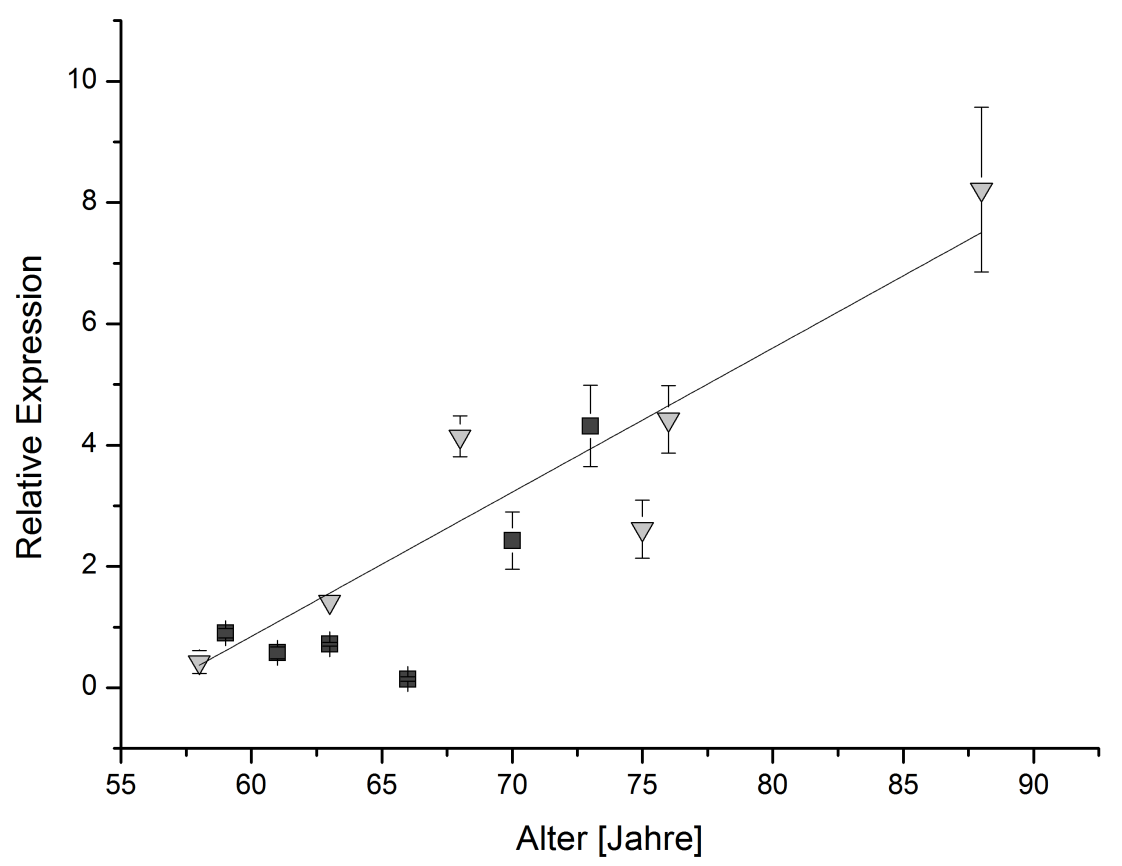

\footnotetext{
Abbildung 3.11: Auftragung der relativen Genexpression gegen das Patientenalter bei Knorpelentnahme. Ordinate: Relative Expression (Ratio). Abszisse: Alter der Patienten in Jahren zum Zeitpunkt der Knorpelentnahme. Die Symbole geben Auskunft über das Geschlecht der Patienten (Dreieck = weiblich; Quadrat $=$ männlich). Zur Veranschaulichung wurde eine Trendlinie eingefügt. Es zeigt sich eine positive Korrelation zwischen Alter und relativer Expression.
} 
Das heißt, je älter die Patienten waren, desto größer schien die Expression des Aromatasegens in den chondrogenen Vorläuferzellen zu sein.

Teilte man daraufhin die Patienten in zwei Gruppen auf und verglich das Patientenkollektiv der unter 67-jährigen mit dem der über 67-jährigen - die Grenze wurde hier gewählt, damit die Gruppen jeweils sechs Patienten einschlossen -, so zeigte sich ein Unterschied in der Genexpression. Abbildung 3.12 erläutert diesen Punkt. Hier wurden die Mittelwerte der relativen Expressionen bei den oben genannten Gruppen mit den Standardabweichungen aufgetragen. In den CPC aus dem Knorpelgewebe der über $67-$ Jährigen war signifikant ( $\mathrm{p}$-Wert 0.001) mehr für die Kodierung des Aromataseenzyms notwendige mRNA exprimiert worden als in den CPC der unter 67-jährigen Patienten.

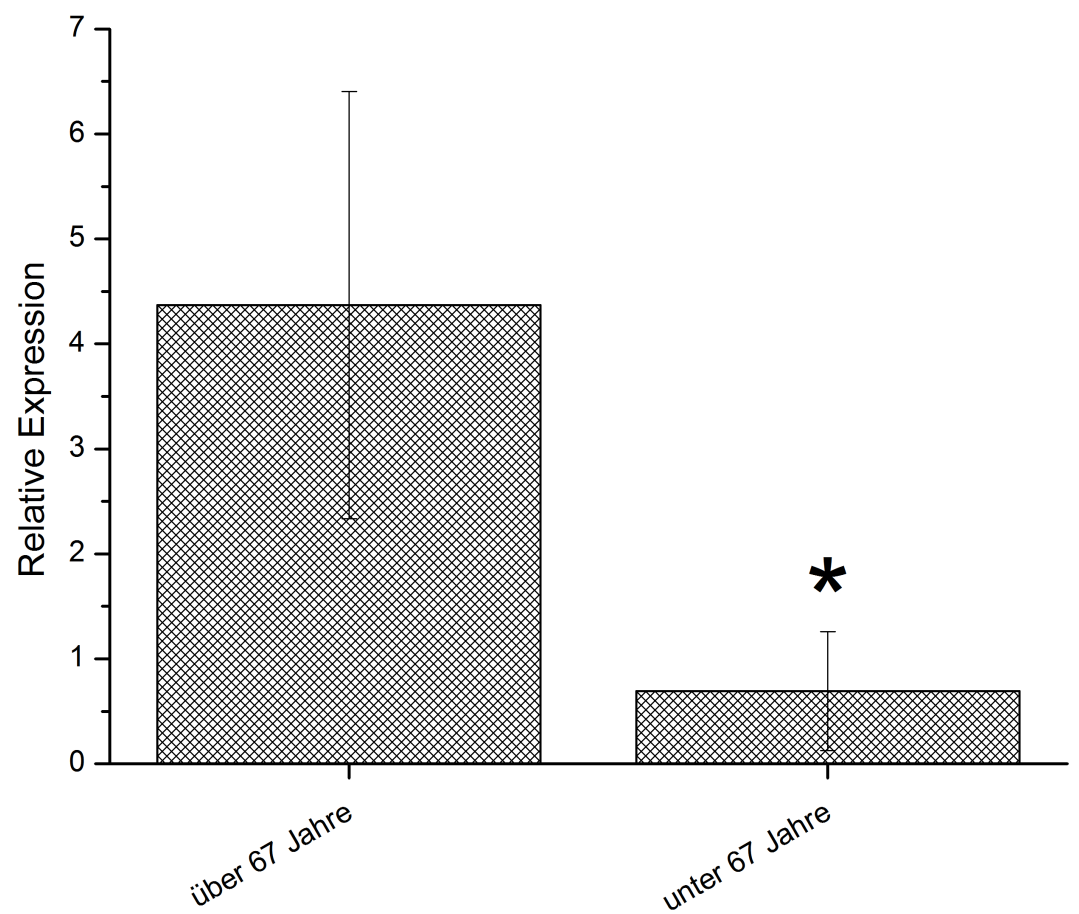

Abbildung 3.12: Gemittelte relative Expressionen des Aromatasegens in CPC von Patienten über 67 und unter 67 Jahre. In den chondrogenen Vorläuferzellen aus dem Knorpelgewebe der über 67-jährigen Patienten ist signifikant $(\mathrm{p}=0.006)$ mehr Aromatase mRNA exprimiert worden als in den CPC der unter 67-Jährigen. 
Da neben dem Geschlecht und dem Alter auch ein erhöhter BMI zu den Risikofaktoren für die Entwicklung einer OA zählt, lag es nahe, analog zu obiger Auftragung, die relative Expression der mRNA in ein Verhältnis zu den BM-Indizes der Patienten zu setzen. Abbildung 3.13 zeigt eben diese Auftragung, wobei auf der Ordinate die Ratio und auf der Abszisse der BMI aufgetragen worden ist. Bei der Betrachtung der Ergebnisse zeigte sich keine solch augenscheinliche Korrelation wie bei dem Vergleich zwischen Expression des Aromatasegens und dem Alter der Patienten. Auch ein Vergleich zweier Patientenkollektive mit höheren und niedrigeren BMI zeigte keinen signifikanten Unterschied in der Expression des Gens. Auffällig war hier, dass nur einer der Patienten nach der Einteilung der WHO (World Health Organization 2000) normalgewichtig war (BMI 18.5-25). Sechs Patienten waren präadipös (BMI 25-30) und fünf Patienten adipös (BMI >30). Hierunter befanden sich drei Patienten im Stadium I (BMI 30-35), ein Patient im Stadium II (BMI 35-40) und ein Patient im Stadium III (BMI >40) der Adipositas.

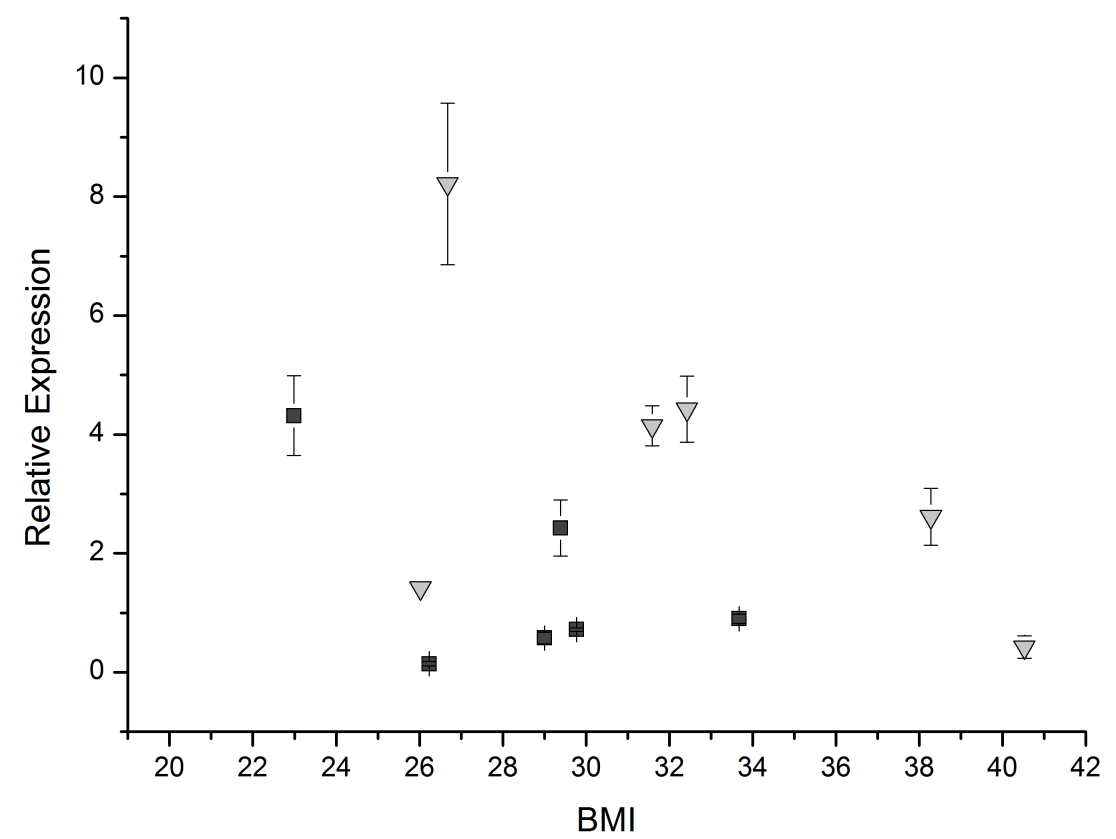

Abbildung 3.13: Auftragung der relativen Genexpression des Aromatasegens gegen den Body Mass Index der Patienten bei Knorpelentnahme. Ordinate: Relative Expression (Ratio). Abszisse: BMI der Patienten zum Zeitpunkt der Knorpelentnahme. Die farblichen Markierungen geben Auskunft über das Geschlecht der Patienten (Dreieck = weiblich; Quadrat = männlich). 


\subsection{Auswirkungen der Hemmung der lokalen Östrogensynthese auf das regenerative Potential chondrogener Vorläuferzellen}

Im Rahmen dieser Arbeit sollte weiterhin überprüft werden, welchen Einfluss die Inhibition der Aromatase mit der Folge einer verminderten lokalen Östrogenproduktion und gleichzeitiger Erhöhung der Testosteron- und Androstendionkonzentration (siehe Abbildung 1.4 auf das chondrogene oder osteogene Potential der CPC und damit auf das Potential der Vorläuferzellen zur Regeneration oder Reparatur eines arthrotischen Defekts des Knorpels ausübte.

Hierzu wurde mittels PCR die Expression der Gene von Kollagen 1, RUNX2, Kollagen 2, SOX9, Aggrecan und MMP13 untersucht. Kollagen 1, welches vor allem im Knochen und im fibrokartilaginären Ersatzgewebe vorhanden ist, wurde zusammen mit RUNX2, einem wichtigen Transkriptionsfaktor zur osteoblastären Differenzierung, und MMP13, einer die Extrazellulärmatrix lysierende Metalloproteinase, als Marker für eine Verschlechterung des osteoarthrotischen Krankheitsbildes mit zunehmendem EZM-Verlust, vermehrter Synthese biomechanisch ineffektiven Faserknorpels und verbreitertem subchondralen Knochen mit osteophytären Anbauten, ausgewählt. Diese drei Gene werden fortan als „proarthrotische Gene“ zusammengefasst.

Kollagen 2, welches vor allem in der EZM des hyalinen Knorpels vorkommt, wurde zusammen mit SOX9, einem Transkriptionsfaktor zur chondrozytären Differenzierung, und Aggrecan, dem zweiten wichtigen Bestandteil der EZM, als Marker zur Verbesserung des osteoarthrotischen Krankheitsbildes ausgewählt. Eine vermehrte Expression dieser drei Gene wäre demnach ein Hinweis auf eine Regeneration des hyalinen Knorpels durch die chondrogenen Vorläuferzellen über eine Differenzierung zu Chondrozyten und über eine Mehrsynthese an Bestandteilen der Extrazellulärmatrix. Diese Gene werden im Folgenden als ,antiarthrotische Gene“ bezeichnet.

Ein Hemmtest der Aromatase wurde daher, wie in Kapitel 2.2.2 beschrieben, an CPC von acht Patienten in späten Stadien der Arthrose durchgeführt. Hierfür wurden aus arthrotischem Knorpelgewebe isolierte und in Alginat kultivierte CPC einmal mit Testosteron, dem Substrat des Aromataseenzyms, einmal mit Formestan, einem Aromatasehemmer der 3. Generation, und einmal mit Testosteron und Formestan in Kombination über 24 Stunden inkubiert. Daraufhin wurde die mRNA aus den Zellen isoliert, in cDNA umgeschrieben, die Expressionen der zu untersuchenden Gene mittels PCR detektiert und 
auf Änderungen hin untersucht. Zur besseren Vergleichbarkeit wurden die gemittelten Ct-Werte (die Standardabweichung betrug in allen Fällen $<0.5$ Ct-Punkte) gegen die jeweilige Kontrollgruppe normiert.

\subsubsection{Vorversuche}

Zunächst wurde der Versuch an Proben von zwei Patienten durchgeführt, um der Frage nachzugehen, ob CPC überhaupt die obigen Gene exprimierten und ob es einen Einfluss auf diese Expression durch die Hemmung der Aromatase gab.

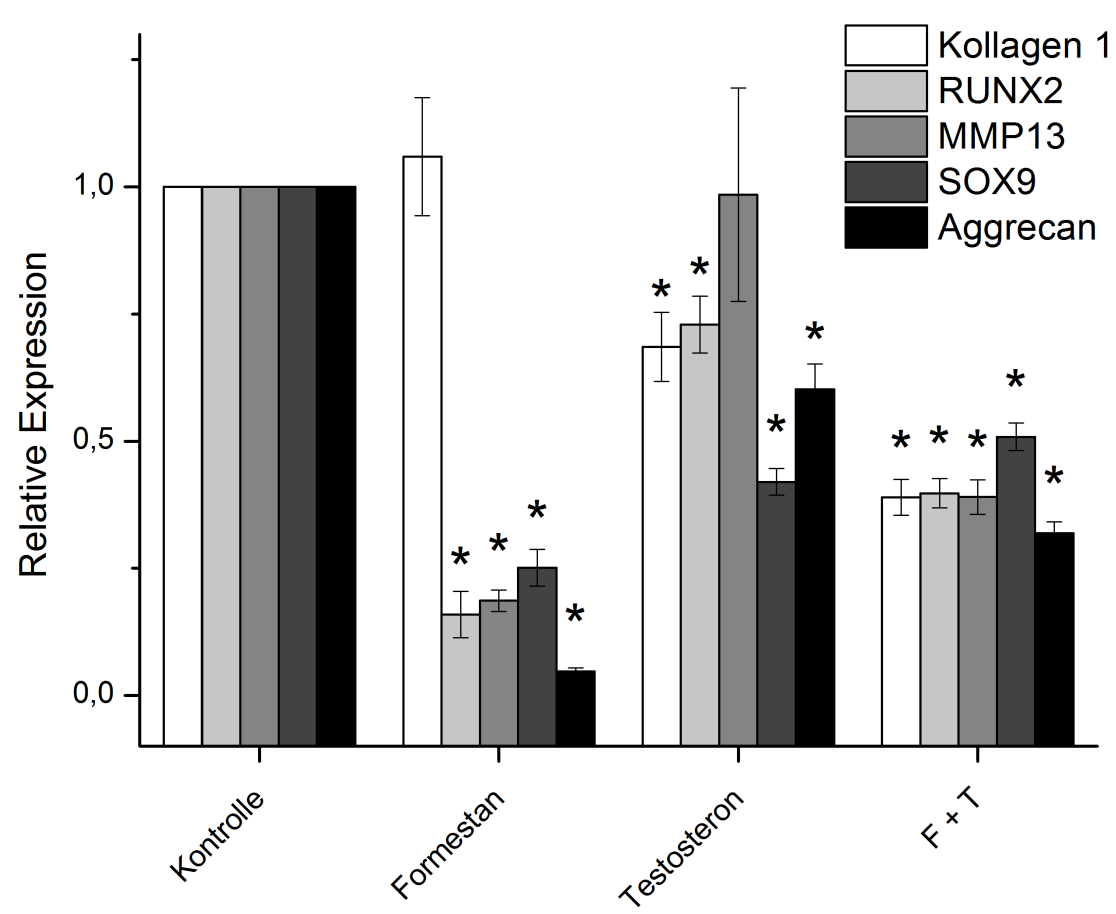

Abbildung 3.14: Relative Expression antiarthrotischer und proarthrotischer Gene nach durchgeführtem Aromatasehemmtest an CPC des weiblichen Patienten 497. Relative Expression nach Inkubation mit dem Aromatasehemmer Formestan, dem Substrat Testosteron und Formestan und Testosteron in Kombination $(\mathrm{F}+\mathrm{T})$ bezogen auf die nicht behandelte Kontrolle. Es kam zu einer statistisch signifikanten (*) Erniedrigung der relativen Expression sowohl der proarthrotischen als auch der antiarthrotischen Gene.

Es zeigte sich, dass die CPC beider Patienten alle sechs zu untersuchenden Gene exprimiert hatten. Bei dem Gen für Kollagen 2 war auffällig, dass die CPC generell sehr wenig mRNA synthetisiert hatten. Aufgrund der geringen Menge an initialer mRNA kam es 
daher zu großen Streuung der Ct-Werte innerhalb eines Durchlaufs, die sich auch durch mehrmalige Wiederholung der PCR-Durchgänge nicht bereinigen ließen. Aufgrund der großen Varianz der Ct-Werte war daher eine valide Aussage über die Expression des Gens für Kollagen 2 nicht möglich. Bei den Vorversuchen stellte sich heraus, dass es bei beiden Patientenproben zu starken Änderungen in der Expression in unterschiedlichen Fraktionen gekommen war. Diese Änderung zeigte sich bei fast allen untersuchten Genen und hatte eine gleich gerichtete Ausprägung. So wurden die Expressionen sowohl der proarthrotischen, als auch der antiarthrotischen Gene in gleicher Weise beeinflusst, was der Erwartung aufgrund der Pathophysiologie und vorhergehender Versuche (Koelling und Miosge 2010) widersprach.

Abbildung 3.14 veranschaulicht exemplarisch diese Problematik. Hier ist die relative Expression der zu untersuchenden Gene (ohne Kollagen 2) dargestellt.

So kam es bei den CPC von Patient 497 nach Inkubation mit den Agenzien zu einer Erniedrigung der relativen Expression sowohl der proarthrotischen als auch der antiarthrotischen Gene in fast allen Fraktionen. Diese Ergebnisse entsprachen, wie bereits erläutert, nicht den Erwartungen und waren am ehesten durch Fehler in der Durchführung des Experimentes, welche zu einer falsch hohen Konzentration der eingesetzten Agenzien führten, zu erklären.

In den folgenden Versuchen wurden diese Fehler, wie in Kapitel 4.2.2 beschrieben, minimiert.

\subsection{2 Änderungen in der Expression proarthrotischer Gene}

Bei den daraufhin durchgeführten Hormontests mit sechs Patienten zeigten sich folgende Ergebnisse für die proarthrotischen Gene:

Bei dem Gen für Kollagen 1 war Folgendes zu beobachten:

Es zeigten sich aussagekräftige Unterschiede in der Kollagen 1-Expression bei vier der sechs Patienten, wie in Abbildung 3.16 dargelegt. Die Ergebnisse der unbeeinflussten Proben sind hier nicht gezeigt. Bei den Patienten 507 (w) und 516 (m) kam es zu einer Verminderung des Kollagen 1 mRNA-Gehaltes in allen drei Versuchsansätzen. Unter Formestan- und Testosterongabe bei Patient 516 (m) auf etwa die Hälfte , bei Formestan und Testosteron in Kombination auf etwa ein Drittel des Kontrollwertes $(p<0.02)$. Bei Patient 507 (w) sank die Genexpression bei allen Versuchen auf etwa ein Drittel der Kontrollprobenexpression $(\mathrm{p}<0.01)$. Bei Patient 531 (w) kam es dagegen zu einer 


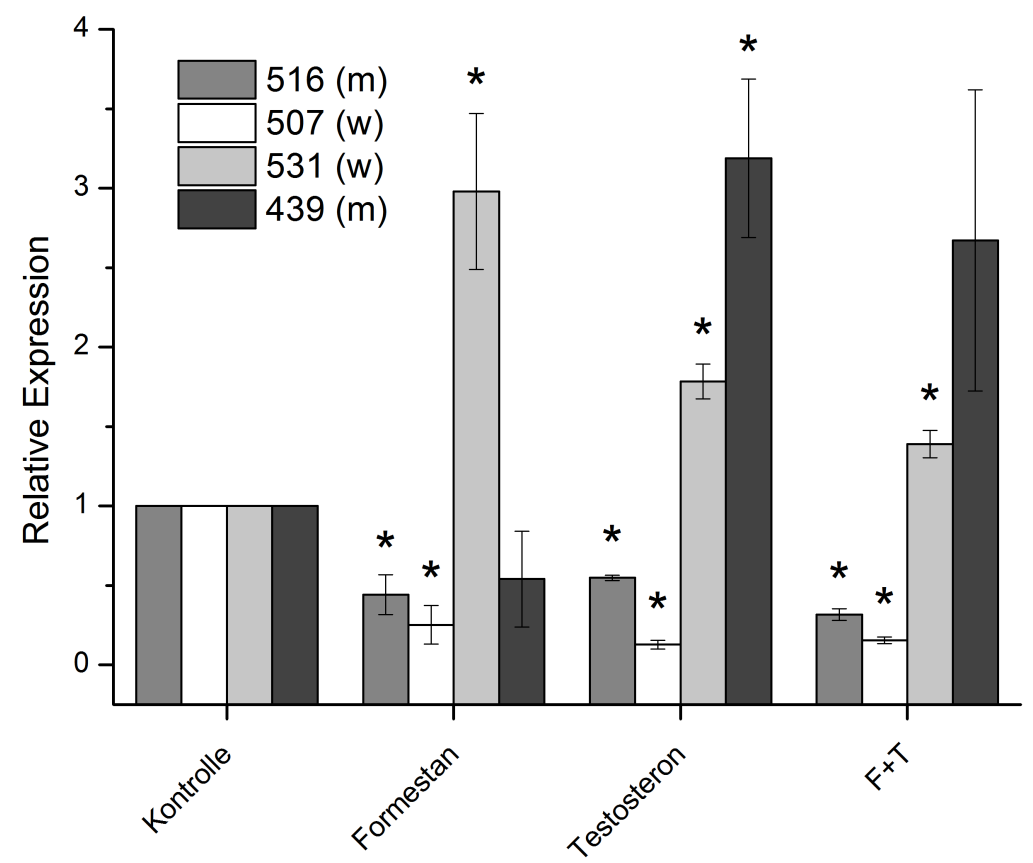

Abbildung 3.15: Relative Genexpression von Kollagen 1 in den CPC von vier Patienten nach Inkubation über 24 Stunden mit Formestan, Testosteron und Formestan mit Testosteron. Signifikante Änderungen mit * markiert. Patient $516(\mathrm{~m})$ : Verminderung der relativen Genexpression in allen Fraktionen $(\mathrm{p}<0.02)$. Patient $507(w)$ : Verminderung der Expression auf etwa ein Drittel im Vergleich zur Kontrolle in allen Fraktionen $(\mathrm{p}<0.01)$. Patient $531(w)$ : Statistisch signifikante Erhöhung der relativen Expression in allen drei Fraktionen. Verdreifachung der relativen Expression von Kollagen 1 nach Formestaninkubation $(\mathrm{p}=0.02)$. Patient $439(w)$ : Etwa Verdreifachung der Genexpression für Kollagen 1 nach Inkubation mit Testosteron $(\mathrm{p}<0.02)$. Keine signifikanten Änderungen in den anderen Fraktionen.

Erhöhung der relativen Expression in allen drei Fraktionen $(p=0.02)$. Bei Patient 439 (m) war eine Verdreifachung der Expression nach Inkubation mit Testosteron $(\mathrm{p}<0.02)$ zu beobachten, während es in den anderen Fraktionen zu keiner signifikanten Änderung in der Expression des Gens kam.

Es ist zu diskutieren, ob dieser Effekt durch die verminderte Konzentration des Östrogens oder durch die folglich erhöhte Konzentration des durch die Blockierung der Östrogenbiosynthese anfallenden Substrates (Testosteron) zustande kam. Festzuhalten ist, dass es bei zwei Patienten zu einer Erhöhung des mRNA-Gehaltes des proarthrotischen Gens für Kollagen 1 kam, während bei den beiden anderen die Expression vermindert war.

Aus pathophysiologischer Sicht würde man aufgrund der chondroprotektiven Eigenschaften der Östrogene nach Inkubation mit dem Aromatasehemmer und folglich verminderter Östrogenbiosynthese mit konsekutiv erhöhter Testosteronkonzentration vor allem bei 
weiblichen Patienten eine Verschlechterung des arthrotischen Krankheitsbildes, also Erhöhung des Expressionslevels für Kollagen 1, vermuten. Nun stellt sich die Frage, warum es bei den CPC der Patienten 531 (w) und 439 (m) zu eben diesem Verlauf und bei den anderen beiden Patienten (weiblich und männlich) zu dem umgekehrten Fall gekommen ist. Basierend auf den Ergebnissen aus Kapitel 3.1.3 könnte man vermuten, dass z.B. die unterschiedliche Expression der Aromatase zu einer unterschiedlichen Effektivität in der Hemmung des Enzyms führen. Vergleicht man die relativen Expressionslevel der Aromatase der CPC der vier Patienten (siehe Abbildung 3.10), so fällt auf, dass die Zellen der Patienten 507 (w) und 516 (m) am meisten Aromatase mRNA synthetisiert hatten. Die CPC der Patienten 531 (w) und 439 (w) hatten eher relativ wenig Aromatase mRNA synthetisiert. Diese Beobachtung spräche eher gegen die obige Theorie. Eine Korrelation zwischen BMI oder Alter der Patienten und den obigen Ergebnissen lässt sich nicht ableiten.

Ob es tatsächlich einen Zusammenhang zwischen der Expression des Aromtasegens und der unterschiedlichen Wirkung des Aromatasehemmers Formestan auf die Synthese von Kollagen 1 mRNA gibt, muss in zukünftigen Untersuchungen geklärt werden. Aufgrund der niedrigen Stichprobenzahl ist es generell schwierig, dahingehend Aussagen zu treffen.

Bei RUNX2 ließen sich nach dem Hormontest bei keiner der Proben signifikante Unterschiede in der Expression feststellen.

Für MMP13 lässt sich folgendes festhalten:

Statistisch signifikante Änderungen in der Expression zeigten sich bei den drei weiblichen der sechs Patienten. Verminderungen in der Expression des Gens für MMP13 zeigten sich bei den Patienten 531 (w) und 507 (w). So reagierten die CPC des erstgenannten Patienten (531) auf die Hormonzugabe in allen drei Fraktionen. Nach Formestan- und Testosterongabe kam es zu einer Verminderung der Expression um etwa die Hälfte $(\mathrm{p}=0.002)$, während die Expression bei der Inkubation mit Formestan mit Testosteron auf ein Drittel des Wertes der Kontrolle gefallen war ( $<<0.001)$. Bei Patient 507 (w) kam es zu einer aussagekräftigen Verringerung auf etwa die Hälfte des Kontrollwertes nach Testosterongabe $(\mathrm{p}<0.001)$. In den CPC des Patienten 541 (w) war nach Inkubation mit Testosteron etwa die 1,5-fache und nach Inkubation mit Formestan und Testosteron in Kombination die etwa zweifache Menge an mRNA synthetisiert worden $(\mathrm{p}<0.001)$.

Es ist zu diskutieren, warum es bei Patient 541 (w) durch Hemmung der Aromatase mit folglich verminderter Östrogenbiosynthese und konsekutiv erhöhter Konzentration 
von Testosteron zu einem Anstieg der Expression des Gens für MMP13 gekommen ist, während es bei den anderen beiden Patienten zu einer Erniedrigung kam. Eine Korrelation zur relativen Expression des Aromatasegens, dem BMI oder dem Alter der Patienten lässt sich hier nicht herstellen. Hier müssten in Zukunft weitere Untersuchungen in größerer Stichprobenzahl erfolgen.

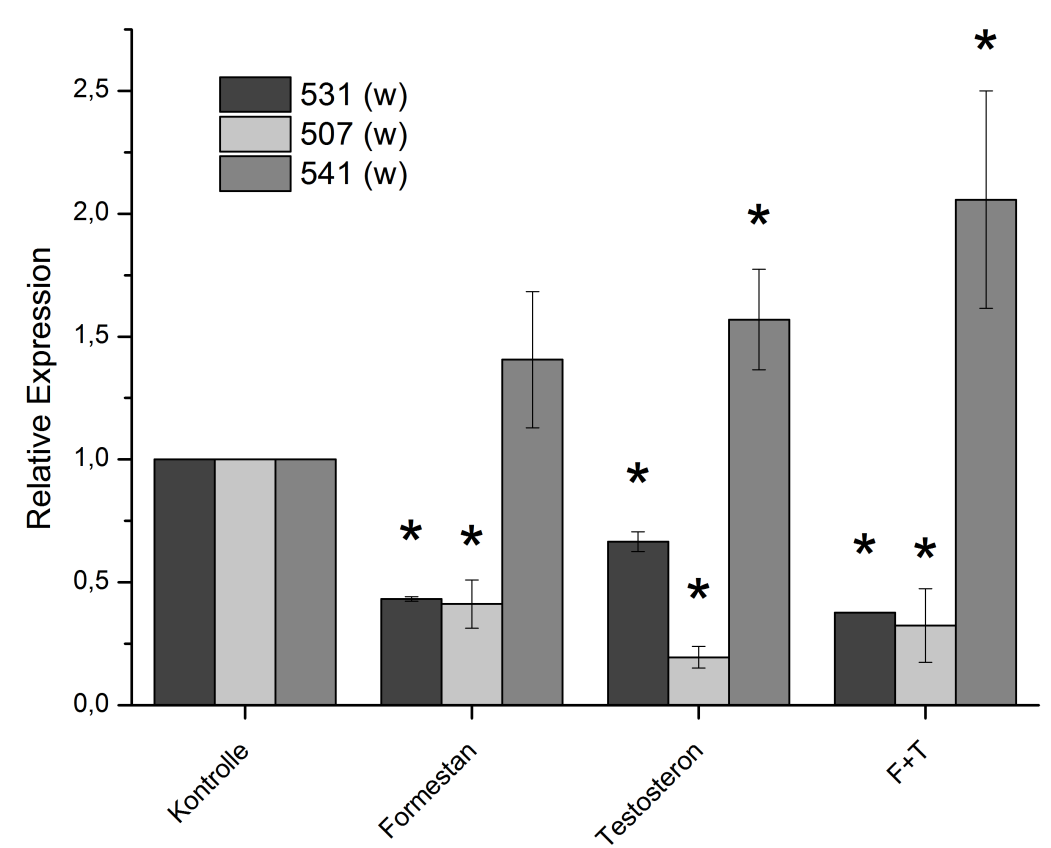

Abbildung 3.16: Relative Genexpression von MMP13 in den CPC dreier Patienten nach Inkubation über 24 Stunden mit Formestan, Testosteron und Formestan mit Testosteron. Statistisch signifikante Änderung markiert mit (*). Patient 531 (w): Es kam zu einer signifikanten Verminderung der Expression in allen drei Zellfraktionen. Nach Formestan- und Testosterongabe auf etwa die Hälfte $(\mathrm{p}=0.002)$ und nach $\mathrm{F}+\mathrm{T}$ auf etwa ein Drittel $(\mathrm{p}<0.001)$ der Expression der Kontrolle. Patient $507(w)$ : Verminderung in der Expression nach Testosterongabe auf unter die Hälfte $(\mathrm{p}<0.001)$ des Kontrollwertes. Patient 541 (w): Signifikanter Anstieg der Expression nach Gabe von Testosteron und nach Gabe von Testosteron sowie Formestan in Kombination $(\mathrm{p}<0.001)$.

Zusammenfassend lässt sich bei der Betrachtung der Expressionslevels der proarthrotischen Gene folgendes konstatieren:

Bei einigen, aber nicht allen, Patienten kam es zu statistisch signifikanten Unterschieden in der Expression der Gene für Kollagen 1 und MMP13 nach der Inkubation mit sowohl Testosteron und Formestan als auch mit beiden Reagenzien in Kombination. Bei RUNX2 
hingegen zeigte sich kein Einfluss durch die Hemmung der Aromatase oder das Vorhandensein des Substrates Testosteron. 


\subsection{3 Änderungen in der Expression antiarthrotischer Gene}

Neben den Genen für Kollagen 1, RUNX2 und MMP13 wurden auch die Expressionen der Gene für Kollagen 2, SOX9 und Aggrecan und der Einfluss der Hemmung der lokalen Östrogenbiosynthese auf diese untersucht.

Es zeigten sich für Kollagen 2 folgende Auffälligkeiten:

In den CPC aller Patienten war sehr wenig Kollagen 2 mRNA synthetisiert worden, wodurch bei der Amplifikation die Fluoreszenzschwelle in der PCR in einem späten Zyklus $(\mathrm{Ct}>30)$ erreicht wurde. Aufgrund der geringen initialen Menge an mRNA kam es daher zu großen Abweichungen der Ct-Werte innerhalb eines Durchlaufs und damit zu Standardabweichungen der Ct-Mittelwerte von über 0.5, welche oft auch durch mehrmalige Wiederholungen der PCR-Durchgänge nicht bereinigen ließen. Abbildung 3.17zeigt exemplarisch die normierten relativen Expressionslevel des Gens für Kollagen 2 von drei Patienten.

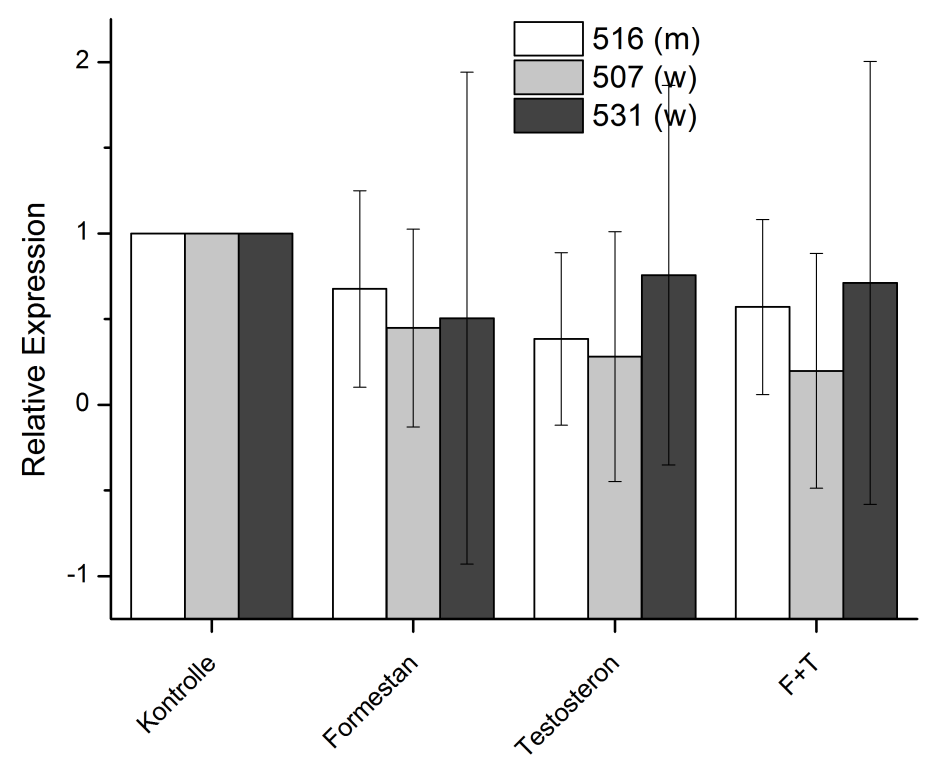

Abbildung 3.17: Relative Genexpression von Kollagen 2 in den CPC dreier Patienten nach Inkubation über 24 Stunden mit Formestan, Testosteron und Formestan mit Testosteron. Es zeigten sich keine statistisch signifikanten Unterschiede in der Expression von Kollagen 2.

Bei SOX9 ließen sich nach dem Hormontest bei keiner der Proben signifikante Unterschiede in der Expression feststellen. Abbildung 3.18 zeigt exemplarisch die normierten 
relativen Expressionslevel des Gens für SOX9 von drei Patienten.

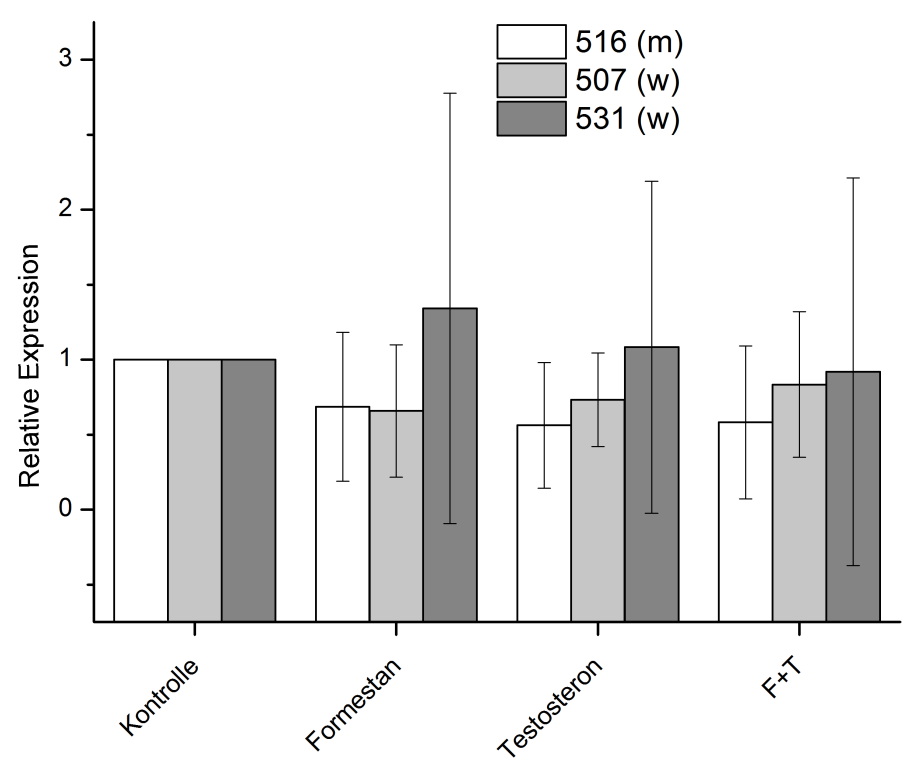

Abbildung 3.18: Relative Genexpression von SOX9 in den CPC dreier Patienten nach Inkubation über 24 Stunden mit Formestan, Testosteron und Formestan mit Testosteron. Es zeigten sich keine statistisch signifikanten Unterschiede in der Expression von SOX9.

Bei dem Gen für Aggrecan ließ sich das Folgende beobachten:

Hier kam es bei einem männlichen Patienten (539) nach Zugabe von Testosteron und Inkubation über 24 Stunden zu einer Verdopplung der Expression des Gens für das Proteoglykan im Verhältnis zur Kontrolle ( $\mathrm{p}<0.001$ ), wie in Abbildung 3.19 zu erkennen ist.

Zusammenfassend ließ sich bei der Betrachtung der Expressionslevels der antiarthrotischen Gene folgendes festhalten:

Die Ergebnisse für Kollagen 2 waren aufgrund der geringen Ausgangsmenge an mRNA und der damit verbundenen großen Streuung der Ct-Werte nicht verwertbar.

Für SOX9 zeigten sich keine Unterschiede in der Expression durch Hemmung der lokalen Östrogenbiosynthese oder Zugabe von Testosteron.

Bei einem Patienten wirkte sich die Zugabe von Testosteron auf die Synthese von Aggrecan-mRNA durch die CPC aus. Es kam zu einer Verdopplung der Expression. 


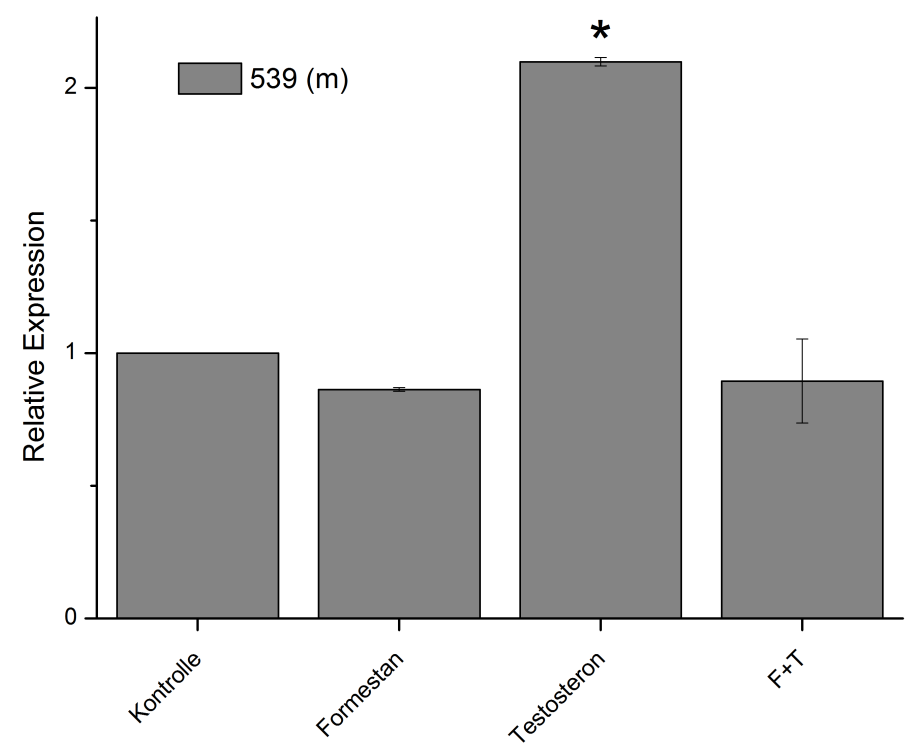

Abbildung 3.19: Relative Genexpression von Aggrecan in den CPC eines männlichen Patienten nach Inkubation über 24 Stunden mit Formestan, Testosteron und Formestan mit Testosteron. Unter Testosteroneinfluss kam es zu einer Verdopplung der Genexpression von Aggrecan. Signifikante Änderungen $(\mathrm{p}<0.001)$ mit * markiert.

\subsubsection{Zusammenfassung der Ergebnisse des Aromatase-Hemmtests}

In der Zusammenschau der Ergebnisse des Aromatase-Hemmtests zeigten sich Veränderungen der Expression der Gene für Kollagen 1, MMP13 und Aggrecan. Diese Veränderungen unterschieden sich zwischen den Patienten, sodass keine eindeutigen Tendenzen feststellbar waren. So reagierten CPC von einigen Patienten auf die Hemmung der Aromatase (ob mit oder ohne zusätzliches Substrat) mit einer Mehrsynthese an Kollagen 1mRNA, während andere CPC die Expression des Gens drosselten. Innerhalb der einzelnen Proben gab es Inkonsistenzen hinsichtlich der Reaktion auf die Aromatasehemmung: So hatten z. B. die CPC des Patienten 531 (w) mit einer Mehrsynthese an Kollagen-mRNA reagiert, während dieselben Zellen gleichzeitig weniger MMP13-mRNA produziert hatten.

Es zeigten sich durch die Versuche keine Änderungen der Expression des Aromatasegens.

Aufgrund der geringen Stichprobenzahl war eine Aussage über geschlechtsspezifische, altersspezifische oder gewichtsspezifische Unterschiede nicht zu treffen. 


\subsection{Zusammenfassung der Ergebnisse}

Die Ergebnisse dieser Arbeit lassen sich wie folgt zusammenfassen:

1. Die Aromatase wurde immunhistochemisch in Kniegelenksgewebe von Patienten mit Arthrose in späten Stadien nachgewiesen. Es fanden sich positiv markierte Zellen in der Tangentialfaser- und der Übergangszone des arthrotischen Knorpels sowie im fibrokartilaginären Reparaturgewebe.

2. In den multipotenten chondrogenen Progenitorzellen (CPC) konnte das Enzym mittels Immunhistochemie und Western Blot nachgewiesen werden.

3. Die Transkription des Aromatasegens, also die Synthese von mRNA aus DNA, fand in den CPC statt. Die mRNA wurde mittels PCR detektiert und es wurden interintividuelle Unterschiede in der Expression sichtbar. Hierbei zeigten sich keine geschlechtsspezifischen oder BMI-spezifischen Unterschiede.

4. Es ließ sich eine Korrelation zwischen dem Alter der Patienten und der Expression des Aromatasegens feststellen: Je älter die Patienten, desto ausgeprägter war die Expression des Gens.

5. Bei dem Hemmtest der Aromatase zeigten sich signifikante Unterschiede der Expressionslevel sowohl der proarthrotischen, als auch der antiarthrotischen Gene. Diese waren aber zwischen den einzelnen Patientenproben als auch innerhalb einer Zellpopulation inkonsistent. Aufgrund der niedrigen Stichprobenzahl ließ sich keine Aussage über geschlechtsspezifische, altersspezifische oder BMI-spezifische Unterschiede machen. 


\section{Diskussion}

\subsection{Lokale Östrogenbiosynthese im Kniegelenk in späten Stadien der Arthrose}

Die Hauptquelle für Östrogene in Männern (Merlotti et al. 2011) und in Frauen in der Postmenopause ist eine Aromatisierungsreaktion in peripheren, extragonadalen Geweben (Simpson 2000). Auch im Gelenk findet diese durch die Aromatase katalysierte Reaktion statt. So konnten Sasano et al. 1997 das Enzym in Osteozyten, Osteoblasten und Chondrozyten nachweisen. Das untersuchte Gewebe war in diesem Fall von Patienten mit Osteooder Chondrosarkomen beziehungsweise bei thoraxchirurgischen Eingriffen entnommen worden. Zudem exprimierten die für die enchondrale Ossifikation zuständigen Chondrozyten der Wachstumsfuge ebenfalls Aromatase (Öz et al. 2001).

Aufgrund des offensichtlichen protektiven Einflusses der Östrogene auf das Gelenk, vor allem bei Frauen, aber auch zum Teil bei Männern, war die Aromatase als Quelle der weiblichen Geschlechtshormone bereits Gegenstand der Erforschung der degenerativen Gelenkerkrankung: Le Bail et al. wiesen 2001 das Enzym in Synoviozyten von Frauen in der Postmenopause nach, die aufgrund einer Arthrose eine Synovektomie erhalten hatten. Zudem konnten Hernández et al. 2008 zeigen, dass sowohl arthrotisches Knochengewebe als auch daraus kultivierte Osteoblasten das Enzym exprimierten.

Mithilfe dieser Arbeit konnte nun mittels Immunhistochemie bestätigt werden, dass in arthrotischem Knorpelgewebe des Kniegelenks ebenfalls Aromatase exprimiert wird, und zwar vor allem dort, wo es im Zuge eines Reparationsversuches zu einer Hyperproliferation von Zellen gekommen war. Die Aromatase fand sich in der Tangentialfaser-, in der Übergangszone und in fibrokartilaginärem Reparaturgewebe. Es wurden intrazelluläre, zytoplasmatische Bereiche angefärbt. Dies ist mit der Lage der Aromatase als membranständiges Enzym des rauen endoplasmatischen Retikulums (Simpson et al. 2002) vereinbar.

Zusammen mit der Tatsache, dass die Östrogenrezeptoren ER $\alpha$ und ER $\beta$ in gelenkbildenden Geweben im Gesunden (Braidman et al. 2001, Nilsson et al. 2003) und während der Arthrose (Ushiyama et al. 1999, Koelling und Miosge 2010) gefunden wurden, bestätigen die Ergebnisse die Vermutung, dass die protektiven Eigenschaften von Östrogenen auf das Gelenk bei Männern und postmenopausalen Frauen aufgrund einer lokalen Synthese und auto- und parakriner Hormonwirkungen entfaltet werden. Diese protektiven 
Eigenschaften wirkten sich über eine Beeinflussung des chondrozytären Stoffwechsels oder eine direkte Interaktion mit Matrix-degradierenden Enzymen (Linn et al. 2012), wie zum Beispiel Matrix-Metalloproteinasen (MMP) aus. So zeigten Claassen et al. 2005, dass Östrogene Chondrozyten aus Rindern vor oxidativem Stress schützten, welcher in der Pathophysiologie der Arthrose eine Rolle spielt. Weiterhin gelten Östrogene als antiinflammatorisch (Straub 2007), vor allem über eine Inhibition des Entzündungsmediators $\mathrm{NF}-\kappa \mathrm{B}$ (engl. nuclear factor kappa-light-chain-enhancer of activated B cells).

Bei Chondrozyten in Kultur bewirkte der Einfluss von Östrogenen eine verminderte Synthese von EZM-degradierenden Enzymen wie MMP-1, -3 und -13 (Claassen et al. 2010). In vitro kultivierte Chondrozyten aus Affen synthetisierten unter Zugabe von Östrogenen vermehrt Proteoglykane (Richmond et al. 2000). Zudem schienen Östrogene die Zellalterung in Chondrozyten zu verlangsamen. 2011 zeigten Breu et al., dass prämenopausale Östrogenkonzentrationen die Verkürzung der Telomere, also der Chromosomenenden, die als nicht kodierende Basenabfolgen für die Stabilität der Chromosomen verantwortlich sind und bei jeder Replikation der DNA verkürzt werden, in Chondrozyten verringerten. Vor dem Hintergrund dieser knorpelprotektiven Eigenschaften der Östrogene ist eine lokale Synthese der Steroidhormone über eine Expression der Aromatase, vor allem während der in der Arthrose ablaufenden knorpeldestruktiven Prozesse, sinnvoll und als Kompensationsreaktion des Organismus zu verstehen.

\subsection{Expression der Aromatase in chondrogenen Progenitorzellen}

Die von Koelling et al. 2009 erstmals charakterisierten chondrogenen Progenitorzellen (CPC), welche in späten Stadien der OA aus dem Knochenmark in defekte Areale des arthrotischen Knorpels migrieren und sich von Osteoblasten, Chondrozyten und mesenchymalen Stammzellen durch die Expression bestimmter Oberflächenmarker und durch distinkte Syntheseeigenschaften unterscheiden, besitzen ein großes Potential zur Regeneration eines Knorpeldefektes.

Diese CPC exprimierten die Östrogenrezeptoren ER $\alpha$ und ER $\beta$ sowie den Androgenrezeptor (AR) und zeigten sich in Inkubationsversuchen in ihrem Potential, defektes Knorpelgewebe zu regenerieren, durch Östrogene bzw. Androgene geschlechtsspezifisch beeinflusst (Koelling und Miosge 2010). Die Zugabe von Östrogenen zu CPC von weiblichen Patienten und die Inkubation von CPC von männlichen Patienten mit Testosteron 
wirkte sich jeweils günstig auf die regenerativen Eigenschaften der CPC aus.

Im Rahmen dieser Arbeit konnte mithilfe unterschiedlicher Methoden zum ersten Mal der Nachweis gelingen, dass die hormonsensitiven chondrogenen Progenitorzellen die Aromatase exprimieren und somit vermutlich in der Lage sind, über die Biosynthese von Östrogenen ihren eigenen Stoffwechsel auto- und parakrin zu beeinflussen.

Das Aromataseenzym ist bereits in Zellen detektiert worden, die aufgrund ihrer Eigenschaften und dem daraus resultierenden Potential zur Regeneration eines Knorpeldefektes den CPC ähneln, sich aber aufgrund von Oberflächenmarkern eindeutig von den Vorläuferzellen unterscheiden. Die sogenannten mesenchymalen Stammzellen (engl. mesenchymal stem cells, MSC) sind multipotent, d.h. sie können sich zu Zellen des Bindegewebes wie Adipozyten, Osteozyten und auch Chondrozyten differenzieren, sie sind zur Migration fähig und man findet sie im Knochenmark (Chamberlain et al. 2007). Aufgrund dieser Eigenschaften werden sie im Zusammenhang mit einem regenerativen Konzept der Arthrosetherapie, nämlich der Geweberekonstruktion (engl. Tissue engineering), erforscht (Tuan et al. 2003, Caplan 2005, Oldershaw 2012). Hierbei wird zur Regeneration eines arthrotischen Knorpeldefektes meist körpereigenes Gewebe in die defekten Areale verpflanzt. Hierfür eignet sich Knorpelgewebe aus anderen Körperstellen mit dem Nachteil, dass intakter Knorpel beschädigt werden muss. Um diese iatrogene Knorpeldestruktion zu umgehen, wird knorpelähnliches Gewebe in vitro synthetisiert (Temenoff und Mikos 2000). Hierzu werden MSC aus dem Knochenmark des Patienten entnommen und in Kulturflaschen vermehrt, chondrogen differenziert und auf ein Trägermaterial (engl. scaffold) aus synthetischen Polymeren (Gunatillake und Adhikari 2003) gebracht. Die differenzierten MSC bilden daraufhin knorpelähnliches Gewebe, welches operativ verpflanzt werden kann.

Diese den CPC ähnelnden mesenchymalen Stammzellen synthetisieren das Aromataseenzym (Heim et al. 2004, Pino et al. 2006), exprimieren Östrogenrezeptoren (Leskelä et al. 2006) und werden durch Östrogene beeinflusst. So konnten Zhou et al. 2001 an MSC aus Ratten zeigen, dass durch die Zugabe von Östrogenen die Apoptoserate der mesenchymalen Stammzellen verringert wurde.

Der mit dieser Arbeit erbrachte Nachweis der Aromatase in den CPC ist im Hinblick auf die Ähnlichkeit mit den MSC mit der Literatur vereinbar und ist vor dem pathophysiologischen Hintergrund der Arthrose plausibel:

Neben den bekannten chondroprotektiven Eigenschaften wirkt sich der Einfluss der 
Östrogene auch direkt auf das regenerative Potential der CPC vor allem aus weiblichen Patienten aus (Koelling und Miosge 2010). Bei Männern und bei Frauen in der Postmenopause, also dem zur Entwicklung einer Arthrose gefährdetsten Patientenkollektiv, wird der größte Teil der Östrogene lokal aus im Blutserum vorhandenen Androgenen synthetisiert, um daraufhin auto- und parakrine Wirkungen zu entfalten. Die in späten Stadien der Arthrose in defekte Areale des hyalinen Gelenkknorpels migrierenden CPC waren in den im Rahmen dieser Arbeit durchgeführten Experimenten potenziell über die Expression des Aromatasegens dazu in der Lage, aus systemisch zirkulierenden Androgenen über die Aromatisierungsreaktion Östrogene herzustellen. Durch diese Möglichkeit der Östrogenbiosynthese könnten die chondrogenen Progenitorzellen vor allem weiblicher Patienten ihr eigenes Potential zur Regeneration defekter Knorpelareale autokrin positiv beeinflussen.

\subsubsection{Die Expression der Aromatase in chondrogenen Progenitorzellen ist altersabhängig}

Ein bedeutender Risikofaktor zur Entwicklung einer Arthrose ist ein hohes Alter. Die Krankheit betrifft vor allem Menschen in mittlerem und höherem Lebensalter. Studien zeigten eine stastistisch signifikante Korrelation zwischen einem hohem Lebensalter und einer erhöhten Inzidenz bzw. Prävalenz sowie einer Progression der OA von Hüft-, Knie- und Handgelenken (Bierma-Zeinstra und Koes 2007, Haugen et al. 2011, PrietoAlhambra et al. 2013). Ein hohes Lebensalter erhöhte das Risiko aufgrund einer Arthrose eine Totalendoprothese der Hüfte zu erhalten (Karlson et al. 2003).

Mithilfe dieser Arbeit konnte gezeigt werden, dass die Expression des für die Aromatase kodierenden Gens in chondrogenen Vorläuferzellen aus späten Stadien der Arthrose altersabhängig ist. Je älter die Patienten mit OA waren, desto mehr Aromatase-mRNA war in den Lysaten der CPC detektierbar.

Diese Beobachtung bestätigte die Ergebnisse aus Untersuchungen anderer Gewebe: 1994 zeigten Bulun und Simpson, dass die Genexpression der Aromatase in Fettgewebe von weiblichen Patienten mit zunehmendem Alter ansteigt. Misso et al. kamen 2005 zu einem ähnlichen Ergebnis.

Eine Erklärung hierfür könnte die mit dem Alter kontinuierlich sinkende Konzentration der im Blut zirkulierenden bioverfügbaren Östrogene sein:

Androgene und Östrogene sind in der Blutbahn an das Sexualhormon-bindende Globulin (SHBG) gebunden. Nur die nicht gebundenen, bioverfügbaren Steroide können ihre Wir- 
kung am Zielort entfalten. Mit zunehmendem Alter kommt es bei beiden Geschlechtern zu einer Zunahme von SHBG im Serum (Lecomte et al. 1998) mit der Folge einer vermehrten Proteinbindung und damit einer Verminderung der bioverfügbaren Hormone (Vermeulen et al. 2002). Als Folge davon könnte es in der Körperperipherie zu einer vermehrten Biosynthese der Aromatase kommen, um den Bedarf an weiblichem Geschlechtshormon über lokale Aromatisierung zu decken.

Demgegenüber stehen viele Ergebnisse aus Untersuchungen, in denen sich keine Korrelation zwischen höherem Lebensalter und gesteigerter Expression der Aromatase zeigte (Nawata et al. 1995, Sasano et al. 1996, Sasano et al. 1997). So fand sich keine altersabhängige Erhöhung der Genexpression oder der Aktivität des Enzyms in Osteoblasten, in Knochen- oder Mammakarzinomgewebe. Diese Daten zeigten, dass die zunehmende Genexpression des Enzyms mit steigendem Alter nicht allein durch ein vermindertes Angebot an bioverfügbaren Steroiden im Blutkreislauf erklärbar war. Vielmehr ist anzunehmen, dass die lokale Östrogenbiosynthese über den individuellen Bedarf des jeweiligen Gewebes reguliert wird. So zeigten sich beispielsweise innerhalb des Gewebes der Brust von Patienten mit einem Mammakarzinom Unterschiede in der Genexpression der Aromatase, nämlich dahingehend, dass in dem vom Tumor befallenen Quadranten höhere Expressionslevel als in den restlichen Quadranten derselben Brust messbar waren (Johnston und Dowsett 2003). Durch den Tumor lokal serzernierte Faktoren hatten höchstwahrscheinlich zu einer Genexpressionserhöhung geführt, um den Bedarf des hormonsensitiven tumorösen Gewebes an Östrogenen zu decken.

Überträgt man diese Beobachtungen auf den in dieser Arbeit diskutierten Sachverhalt, so ist anzunehmen, dass mit zunehmendem Patientenalter in dem arthrotisch veränderten Gelenk vermutlich der Bedarf der CPC an Östrogenen ansteigt, was in einer Expressionserhöhung des für die Aromatase kodierenden Gens resultiert.

Da mit steigendem Patientenalter auch die Inzidenz, Prävalenz und die Schwere der Arthrose zunimmt, könnte man annehmen, dass der Bedarf der CPC an Östrogenen aufgrund einer zunehmenden Aggravation der Krankheit ansteigt. Ein erhöhter Bedarf an Östrogenen aufgrund einer Verschlechterung des arthrotischen Krankheitsbildes wäre vor dem Hintergrund der chondroprotektiven und auf die CPC modulatorisch wirkenden Eigenschaften der Östrogene als Erklärung für die vermehrte Expression des Aromatasegens nachvollziehbar. Somit könnte es in den chondrogenen Vorläuferzellen kompensatorisch im Zuge eines Reparationsversuches zu einer solchen Genexpressionserhöhung kommen. Allerdings wird in diesem Fall einerseits die Abhängigkeit von erhöhtem Lebensalter und der Schwere der Arthrose und andererseits die Abhängigkeit zwischen fortgeschrittenem 
Alter und vermehrter Genexpression miteinander verglichen. Ein kausaler Zusammenhang zwischen Schwere des Krankheitsbildes und der erhöhten Expression des Aromatasegens lässt sich hieraus nicht automatisch ableiten, weshalb gesonderte Untersuchungen dahingehend in Zukunft erfolgen müssten.

\subsubsection{Inhibition der Aromatase in chondrogenen Progenitorzellen aus späten Stadien der Arthrose}

Die multipotenten chondrogenen Progenitorzellen aus späten Stadien der Arthrose exprimieren das für die Aromatase kodierende Gen. Mit zunehmendem Alter der Patienten steigt diese Expression an. Koelling und Miosge konnten 2010 zeigen, dass sich physiologische Konzentrationen an Testosteron bei CPC aus männlichen Patienten günstig auf das chondrogene Potential der Vorläuferzellen auswirkten. Vor diesem Hintergrund sollte überprüft werden, welchen Einfluss eine Inhibition der Aromatase in den CPC auf eben dieses regenerative Potential besitzt. Mit der Folge einer erhöhten lokalen Testosteron- und einer erniedrigten lokalen Östrogenkonzentration war eine Verbesserung des chondrogenen Potentials bei CPC aus Männern und eine Verschlechterung des Potentials bei CPC aus Frauen erwartet worden.

In Vorversuchen sollte der Frage nachgegangen werden, ob die CPC überhaupt die im Rahmen dieser Arbeit genannten proarthrotischen und antiarthrotischen Gene exprimierten und ob die Inhibition der Aromatase Einfluss auf diese Expression nimmt. Hierzu wurde zunächst der Inhibitionsversuch an CPC von zwei Patienten durchgeführt. Es fanden sich statistisch signifikante Änderungen in der Expression, die gleichermaßen proarthrotische wie antiarthrotische Gene betraf. Am ehesten ist hier von Fehlern bei der Durchführung des Hemmversuchs auszugehen: Die Durchführung der Alginatzellkultur sowie die benutzten Methoden zur Detektion und Quantifizierung von genetischem Material, von der Gewinnung der mRNA bis zur Durchführung der PCR, beruhten auf vielfach durchgeführten und erprobten Versuchsprotokollen, weshalb diese als Ursache der widersprüchlichen Ergebnisse eher ausschieden.

Am ehesten waren diese Ergebnisse vereinbar mit einer falsch hohen Konzentration der zugegebenen Substanzen. In der Literatur ist beschrieben, wie eine unphysiologisch hohe Konzentration an Testosteron die Apoptose in neuronalen Zellen einleitet (Estrada et al. 2006).

Die Endkonzentrationen der jeweiligen Stoffe bewegte sich im nanomolaren Bereich, 
weshalb es höchstwahrscheinlich bei der Herstellung der Gemische durch zu große Verdünnungsschritte und durch dabei verwendete zu große, ungenaue Pipetten zu einer fehlerhaften Endkonzentration gekommen war.

In den nachfolgenden Versuchen wurden die Lösungen in deutlich kleineren Schritten und unter der Verwendung von kleineren Pipetten mit geringeren systemischen Messfehlern hergestellt.

In den darauffolgenden an CPC von sechs Patienten durchgeführten Hemmversuchen konnten die obigen Erwartungen nicht bestätigt werden. Jedoch zeigten sich bei einigen Proben signifikante Unterschiede in der Expression der untersuchten Gene und somit bestätigen die Ergebnisse eine mögliche Beeinflussung des regenerativen Potentials der CPC durch eine Hemmung der lokalen Östrogenbiosynthese. Aufgrund der geringen Stichprobenzahl zeigten sich jedoch keine eindeutig ableitbaren Tendenzen. Dies macht weiterführende Untersuchungen dieses Sachverhaltes notwendig.

\subsection{Klinische Relevanz der Arbeit}

Östrogene entfalten bei Männern und vor allem bei Frauen chondroprotektive Wirkungen auf die gelenkbildenden Gewebe. Die Steroidhormone werden bei Männern und Frauen in der Postmenopause vor allem lokal aus im Blut zirkulierenden Androgenen produziert. Mithilfe dieser Arbeit konnte gezeigt werden, dass diese lokale, durch die Aromatase katalysierte Biosynthese der Östrogene sowohl in arthrotischem Knorpel des Kniegelenks, als auch in chondrogenen Progenitorzellen möglich ist und dass die Expression des für die Aromatase kodierenden Gens altersabhängig ist.

Therapeutisch könnte man sich die gelenkprotektiven Eigenschaften der Östrogene durch eine exogene Zufuhr zunutze machen. Tatsächlich konnte man bei Frauen, die aufgrund von Wechseljahrsbeschwerden oder postmenopausaler Osteoporose eine Hormonersatztherapie (engl. hormone replacement therapy, HRT) erhielten und zudem an Arthrose erkrankt waren, eine radiologisch detektierbare Verbesserung des OA-Schweregrades erkennen (Spector et al. 1997). Auch im Tierversuch ließen sich diese Beobachtungen bestätigen (Ham et al. 2002).

In den 1990er Jahren erhielten sehr viele Frauen eine HRT zur Behandlung von Wechseljahrsbeschwerden mit typischen Symptomen wie Hitzewallungen, Schlafstörungen und depressiven Verstimmungen. Untersuchungen von Felson et al. (1993) zeigten 
zudem, dass sich die HRT positiv auf die Knochendichte auswirkte und damit das Osteoporoserisiko senkte. In der Folge zeigten sich nach massenhaftem Einsatz der HRT viele Nebenwirkungen wie die Erhöhung des Risikos für die Enwicklung einer koronaren Herzkrankheit, eines Apoplex, einer Thrombose und bei langjähriger Anwendung ein erhöhtes Risiko für Brustkrebs (Nelson et al. 2002). Eine HRT wird daher mittlerweile nur noch bei Lebensqualität-einschränkenden, starken Wechseljahrsbeschwerden in niedrigeren Dosierungen und nicht als Osteoporoseprophylaxe allein durchgeführt. Zudem wird vor der Behandlung ein Hormonstatus erstellt.

Eine systemische Gabe der Steroidhormone zur Behandlung oder Prophylaxe einer Arthrose empfiehlt sich daher aufgrund des breiten Nebenwirkungsspektrums nicht.

Die lokale Gabe von Östrogenen durch z. B. intraatrikuläre Injektionen wäre eine denkbare therapeutische Alternative, die womöglich mit weniger systemischen Nebenwirkungen verbunden wäre. Im Tierversuch zeigten sich hierbei jedoch paradoxe Wirkungen (Roman-Blas et al. 2009): Intrartikuläre Injektionen von Östrogenen führten zu einer Verschlechterung des arthrotischen Krankheitsbildes bei ovarektomierten Kaninchen (Tsai und Liu 1993), wobei die Verschlechterung bei hohen Östrogenkonzentrationen ausgeprägter war.

Aufgrund der paradoxen Wirkungen der direkten Gabe von Östrogenen könnte eine andere, indirektere therapeutische Strategie sinnvoll sein. Wie mit dieser Arbeit gezeigt wurde, sind die hormonsensiblen und in ihrem Regenerationspotential durch Geschlechtshormone beeinflussbaren chondrogenen Progenitorzellen aus späten Stadien der Arthrose theoretisch in der Lage, Östrogene zu synthetisieren. Über eine Stimulierung dieser Östrogenbiosynthese mittels Induktion der Genexpression der Aromatase oder einer Aktivitätssteigerung des Enzyms könnte vor allem in CPC aus weiblichen Patienten eine positive Beeinflussung des Potentials der Zellen zur Regeneration eines Knorpeldefektes erreicht werden.

Die Ergebnisse von Simpson et al. (1981), McTernan et al. (2000, 2002) und anderen zeigten, dass sowohl die Expression des Aromataseenzyms als auch deren Aktivität vor allem bei Frauen durch Glukokortikoide induziert werden kann.

Dass eine intraartikuläre Injektion eines Glukokortikoids zu einer Besserung der Symptomatik der OA führte (Bellamy et al. 2009), unterstreicht diesen Aspekt. Neben der antiinflammatorischen Komponente wirkte das Nebennierenrindenhormon also vermutlich auch über eine positive Regulierung der im kranken Gelenk vorhandenen Aromatase. 
Dass die in Folge vermehrt synthetisierten Östrogene zusätzlich antiinflammatorische Wirkungen entfalteten, wurde bereits an anderer Stelle erläutert. Es ließ sich weiterhin bestätigen, dass die Aromatase in ihrer Aktivität oder der Genexpression durch diverse andere Stoffe wie Vitamin D (Tanaka et al. 1996, Enjuanes et al. 2005) oder Leptin (Pino et al. 2006) induziert werden könnte.

Die gezielte Induktion der lokalen Biosynthese von Östrogenen im Gelenk könnte also eine therapeutische Option in der Osteoarthrose bei bestimmten Patienten darstellen.

Inhibitoren der Aromatase werden erfolgreich in der Therapie des hormonsensitiven Mammakarzinoms eingesetzt (Johnston und Dowsett 2003). Sie bewirken als kompetetive Antagonisten, wie z. B. Formestan, oder als nichtkompetetive Antagonisten, wie z. B. Letrozol, eine Verminderung der Östrogenbiosynthese. Dass die Einnahme eines solchen Aromatasehemmers auch Einfluss auf Gelenkerkrankungen hat, zeigten Sestak et al. 2008, indem sie eine positive Korrelation zwischen der Einnahme eines Aromatasehemmers und dem Auftreten von Gelenksymptomen aufzeigten. Vor dem Hintergrund der positiven Beeinflussbarkeit der chondrogenen Progenitorzellen aus männlichen Patienten durch Testosteron (Koelling und Miosge 2010) wurde ein Hemmtest der Aromatase durchgeführt. Hierbei zeigten sich aufgrund der geringen Stichprobenzahl keine eindeutigen Ergebnisse, weshalb in dieser Richtung weitere Untersuchungen erfolgen müssten. Dennoch sind die Aromatasehemmstoffe ein Instrument zur Beeinflussbarkeit des lokalen Östrogenstoffwechsels innerhalb des arthrotischen Gelenks und könnten zur Entwicklung neuer Therapien beitragen.

Die gezielte Regulierbarkeit der Östrogenbiosynthese könnte besonders bedeutsam für Patienten in höherem Lebensalter sein, da, wie mit dieser Arbeit bestätigt, die chondrogenen Progenitorzellen mit steigendem Alter der Patienten vermehrt das Gen für die Aromatase exprimierten. Die potenzielle Regenerationsfähigkeit der CPC könnte also bei älteren Menschen mit Arthrose effektiver ausgenutzt werden.

Das in defekten Knorpelarealen, in fibrokartilaginärem Reparaturgewebe und in chondrogenen Progenitorzellen vorhandene Aromataseenzym stellt einen Angriffspunkt zur Entwicklung neuer therapeutischer Strategien zur Behandlung der Arthrose dar. Aufgrund des offensichtlichen Einflusses der Geschlechtshormone auf den Verlauf der degenerativen Gelenkerkrankung ist das essentielle Enzym in der Biosynthese der Östrogene und seine potenzielle Beeinflussbarkeit durch bereits vorhandene Agenzien ein entscheidender Parameter zur Entwicklung neuer therapeutischer Konzepte. Über eine gezielte Regulie- 
rung der Östrogenbiosynthese ließe sich vor allem das enorme regenerative Potential der chondrogenen Progenitorzellen, vor allem bei älteren Patienten, besser ausnutzen.

Die komplexen und zum Teil paradoxen Wirkungen der Geschlechtshormone auf das erkrankte Gelenk sind jedoch bisher nur zum Teil verstanden und müssen in Zukunft genauer untersucht werden. 


\section{Zusammenfassung}

Im Rahmen dieser experimentellen Arbeit wurde der Stellenwert der lokalen Östrogenbiosynthese in späten Stadien der Arthrose und in multipotenten chondrogenen Progenitorzellen (CPC) untersucht, sowie der Einfluss dieses Geschlechtshormonstoffwechsels auf die Zellen und ihr Potenzial zur Regeneration eines Knorpeldefektes beleuchtet.

Hierfür wurden Gewebeproben aus Kniegelenken von Patienten verwendet, die im Rahmen einer Arthrose eine Totalendoprothese des Kniegelenks erhalten hatten. In die defekten Knorpelareale migrierende chondrogene Progenitorzellen wurden aus den Geweben isoliert und weiter verwendet.

Immunhistochemisch konnte das für die Östrogenbiosynthese essentielle Enzym Aromatase in Arealen des destruierten Gelenkknorpels nachgewiesen werden, in denen es reaktiv zu einer Zellhyperproliferation gekommen war. Das Protein wurde weiterhin durch Immunhistochemie und Western Blot in den CPC detektiert. Die Expression des für die Aromatase kodierenden Gens wurde mittels Amplifikation durch Polymerasekettenreaktion in den CPC nachgewiesen. Es zeigten sich hierbei altersabhängige Unterschiede in der Expression. Je älter der Patient bei Gewebeentnahme war, desto ausgeprägter zeigte sich die Expression des Aromatasegens in den CPC.

Die Ergebnisse dieser Arbeit zeigen, dass eine lokale Östrogenbiosynthese in arthrotischem Knorpel und in chondrogenen Vorläuferzellen potenziell möglich ist.

Geschlechtshormone beeinflussen bei Frauen und bei Männern den Verlauf der Arthrose und wirken sich geschlechtsspezifisch auf das regenerative Potential der CPC aus. Die Tatsache, dass bei Männern und Frauen in der Postmenopause der hauptsächliche Teil der Östrogene in den extragonadalen Geweben synthetisiert wird, unterstreicht die Relevanz der hier nachgewiesenen Aromatase in der Pathophysiologie der Arthrose.

Eine gezielte Regulation der Aktivität des Aromataseenzyms mit der Folge einer gezielten Regulation der lokalen Androgen- und Östrogenkonzentrationen könnte dazu beitragen, den Verlauf der Arthrose positiv zu beeinflussen und das regenerative Potential der chondrogenen Vorläuferzellen zu steuern. Eine besondere Bedeutung könnte dieser Therapieansatz bei Patienten in höherem Lebensalter erhalten, da hier die chondrogenen Progenitorzellen vermehrt das Aromataseenzym ausbilden. 


\section{Literaturverzeichnis}

Altman R, Asch E, Bloch D, Bole G, Borenstein D, Brandt K, Christy W, Cooke TD, Greenwald R, Hochberg M et al. (1986): Development of criteria for the classification and reporting of Osteoarthritis. Classification of Osteoarthritis of the Knee. Arthritis Rheum 29(8), 1039-1049

Aumüller G, Aust G, Doll A, Engele J, Kirsch J, Mense S, Reißig D, Salvetter J, Schmidt W, Schmitz F et al.: Anatomie. (Duale Reihe), 1. Auflage; Georg Thieme Verlag, Stuttgart 2007

Bellamy N, Campbell J, Welch V, Gee TL, Bourne R, Wells GA (2009): Intraarticular corticosteroid for treatment of osteoarthritis of the knee (Review). Cochrane Database Syst Rev $\underline{2}, 1-2017$

Berenbaum F, Eymard F, Houard X (2013): Osteoarthritis, inflammation and obesity. Curr Opin Rheumatol 25, 114-118

Berthois Y, Katzenellenbogen JA, Katzenellenbogen BS (1986): Phenol red in tissue culture media is a weak estrogen: Implications concerning the study of estrogen-responsive cells in culture. Proc Natl Acad Sci U S A $\underline{83}, 2496-2500$

Bierma-Zeinstra SMA, Koes BW (2007): Risk factors and prognostic factors of hip and knee osteoarthritis. Nat Clin Pract Rheumatol 3, 78-85

Blagojevic M, Jinks C, Jeffery A, Jordan KP (2010): Risk factors for onset of osteoarthritis of the knee in older adults: a systematic review and meta-analysis. Osteoarthritis Cartilage 18, 24-33

Böcker W, Denk H, Heitz PU, Moch H: Pathologie. 4. Auflage; Elsevier GmbH, München 2008

Boyan BD, Hart DA, Enoka RM, Nicolella DP, Resnick E, Berkley KJ, Sluka KA, Kwoh CK, Tosi LL, O'Connor MI et al. (2013): Hormonal modulation of connective tissue 
homeostasis and sex differences in risk for osteoarthritis of the knee. Biol Sex Differ $\underline{4}, 3$

Braidman IP, Hainey L, Batra G, Selby PL, Saunders PT, Hoyland JA (2001): Localization of estrogen receptor beta protein expression in adult human bone. J Bone Miner Res 16, 214-220

Breu A, Sprinzing B, Merkl K, Bechmann V, Kujat R, Jenei-Lanzl Z, Prantl L, Angele $P$ (2011): Estrogen reduces cellular aging in human mesenchymal stem cells and chondrocytes. J Orthop Res 29, 1563-1571

Buckwalter JA, Mankin HJ, Grodzinsky AJ (2005): Articular Cartilage and Osteoarthritis. Instr Course Lect 54, 465-480

Bulun SE, Simpson R (1994): Competetive reverse transcription-polymerase chain reaction analysis indicates that levels of aromatase cytochrome P450 transcripts in adipose tissue of buttocks, thighs, and abdomen of women increase with advancing age. J Clin Endocrinol Metab 18, 428-432

Caplan AI (2005): Mesenchymal Stem Cells: Cell-Based Reconstructive Therapy in Orthopedics. Tissue Eng 11, 1198-1209

Chamberlain G, Fox J, Ashton B, Middleton J (2007): Concise review: mesenchymal stem cells: their phenotype, differentiation capacity, immunological features, and potential for homing. Stem Cells $\underline{25}$, 2739-2749

Chen FH, Rousche KT, Tuan RS (2006): Technology Insight: adult stem cells in cartilage regeneration and tissue engineering. Nat Clin Pract Rheumatol 2, 373-382

Claassen H, Schünke M, Kurz B (2005): Estradiol protects cultured articular chondrocytes from oxygen-radical-induced damage. Cell Tissue Res $\underline{319}$, 439-445

Claassen H, Steffen R, Hassenpflug J, Varoga D, Wruck CJ, Brandenburg LO, Pufe $\mathrm{T}$ (2010): $17 \beta$-estradiol reduces expression of MMP-1, -3 , and -13 in human primary articular chondrocytes from female patients cultured in a three dimensional alginate 
system. Cell Tissue Res 342, 283-293

Czajka-Oraniec I, Simpson ER (2010): Aromatase research and its clinical significance. J Endocrinol 61, 126-134

Deutsche Gesellschaft für Orthopädie und Orthopädische Chirurgie (2009): S3-Leitlinie Koxarthrose. URL: http://www.leitliniensekretariat.de/files/ MyLayout/pdf/033-0011_S3_Koxarthrose_2009-11.pdf, Download am 13.05.2013

Enjuanes A, Garcia-Giralt N, Supervia A, Nogues X, Ruiz-Gaspa S, Bustamante M, Mellibovsky L, Grinberg D, Balcells S, Diez-Perez A (2005): Functional analysis of the I.3, I.6, pII and I.4 promoters of CYP19 (aromatase) gene in human osteoblasts and their role in vitamin D and dexamethasone stimulation. Eur J Endocrinol 153, 981-988

Estrada M, Varshney A, Ehrlich BE (2006): Elevated testosterone induces apoptosis in neuronal cells. J Biol Chem $\underline{281}$, 25492-501

Felson DT (1990): The epidemiology of knee osteoarthritis: results from the Framingham Osteoarthritis Study. Semin Arthritis Rheum 20, 42-50

Felson DT (2006): Osteoarthritis of the Knee. N Engl J Med 354, 841-848

Felson DT, Zhang Y, Hannan MT, Kiel DP, Wilson PWF, Anderson JJ (1993): The effect of postmenopausal estrogen therapy on bone density in elderly women. N Engl J Med $\underline{329}, 1141-1146$

Felson DT, Lawrence RC, Dieppe PA, Hirsch R, Helmick CG, Jordan JM, Kington RS, Lane NE, Nevitt MC, Zhang Y et al. (2000): Osteoarthritis: new insights. Part 1: the disease and its risk factors. Ann Intern Med 133, 637-639

Fields GB (2013): Interstitial collagen catabolism. J Biol Chem 288, 8785-8793

Fox AJF, Bedi A, Rodeo SA (2009): The basic science of articular cartilage: structure, composition, and function. Sports Health $\underline{1}, 461-468$ 
Fransen M, Bridgett L, March L, Hoy D, Penserga E, Brooks P (2011): The epidemiology of osteoarthritis in Asia. Int J Rheum Dis 14, 113-121

Fuchs J, Rabenberg M, Scheidt-Nave C (2013): Prävalenz ausgewählter muskuloskelettaler Erkrankungen. Ergebnisse der Studie zur Gesundheit Erwachsener in Deutschland (DEGS1). Bundesgesundheitsbl ㅌ6, 678-686

Ghosh D, Lo J, Morton D, Valette D, Xi J, Griswold J, Hubbell S, Egbuta C, Jiang W, An J et al. (2012): Novel aromatase inhibitors by structure-guided design. J Med Chem $\underline{55}, 8464-8476$

Goldring MB (2000): The role of the chondrocyte in osteoarthritis. Arthritis Rheum $\underline{43}$, 1916-1926

Goldring MB (2012): Chondrogenesis, chondrocyte differentiation, and articular cartilage metabolism in health and osteoarthritis. Ther Adv Musculoskelet Dis $\underline{4}, 269-285$

Goldring MB, Marcu KB (2009): Cartilage homeostasis in health and rheumatic diseases. Arthritis Res Ther 11, 2-24

Grady D (2006): Management of Menopausal Symptoms. N Engl J Med 355, 2338-2347

Grodin JM, Siiteri PK, MacDonald PC (1973): Source of estrogen production in postmenopausal women. J Clin Endocrinol Metab $\underline{36}$, 207-214

Gunatillake PA, Adhikari R (2003): Biodegradable synthetic polymers for tissue engineering. Eur Cell Mater $\underline{5}, 1-16$

Ham KD, Loeser RF, Lindgren BR, Carlson CS (2002): Effects of long-term estrogen replacement therapy on osteoarthritis severity in cynomolgus monkeys. Arthritis Rheum $\underline{46}, 1956-1964$

Haugen IK, Englund M, Aliabadi P, Niu J, Clancy M, Kvien TK, Felson DT (2011): Prevalence, incidence and progression of hand osteoarthritis in the general population: 
the Framingham Osteoarthritis Study. Ann Rheum Dis $\underline{70}$, 1581-1586

Häuselmann HJ, Fernandes RJ, Mok SS, Schmid TM, Block JA, Aydelotte MB, Kuettner KE, Thonar EJ (1994): Phenotypic stability of bovine articular chondrocytes after long-term culture in alginate beads. J Cell Sci 107, 17-27

Heim M, Frank O, Kampmann G, Sochocky N, Pennimpede T, Fuchs P, Hunziker W, Weber P, Martin I, Bendik I (2004): The phytoestrogen genistein enhances osteogenesis and represses adipogenic differentiation of human primary bone marrow stromal cells. Endocrinology $\underline{145}, 848-859$

Helmick CG, Felson DT, Lawrence RC, Gabriel S, Hirsch R, Kwoh CK, Liang MH, Kremers HM, Mayes MD, Merkel PA et al. (2008): Estimates of the prevalence of arthritis and other rheumatic conditions in the United States. Part I. Arthritis Rheum $\underline{58}$, $15-25$

Hernández JL, Garcés CM, Sumillera M, Fernández-Aldasoro EV, Garcia-Ibarbia C, Ortiz-Gómez JA, Arozamena J, Alonso MA, Riancho JA (2008): Aromatase expression in osteoarthritic and osteoporotic bone. Arthritis Rheum 58, 1696-1700

Horton WE, Bennion P, Yang L (2006): Cellular, molecular, and matrix changes in cartilage during aging and osteoarthritis. J Musculoskelet Neuronal Interact $\underline{6}, 379-381$

Hunter DJ, Felson DT (2006): Osteoarthritis. BMJ 332, 639-642

Johnston SRD, Dowsett M (2003): Aromatase inhibitors for breast cancer: lessons from the laboratory. Nat Rev Cancer $\underline{3}, 821-831$

Junqueira LCU, Carneiro J, Gratzl M: Histologie. 6. Auflage; Springer Medizin Verlag, Heidelberg 2005

Karlson EW, Mandl LA, Aweh GN, Sangha O, Liang MH, Grodstein F (2003): Total hip replacement due to osteoarthritis: the importance of age, obesity, and other modifiable risk factors. Am J Med 114, 93-98 
Koelling S, Miosge N (2010): Sex differences of chondrogenic progenitor cells in late stages of osteoarthritis. Arthritis Rheum $\underline{62}$, 1077-1087

Koelling S, Kruegel J, Irmer M, Path JR, Sadowski B, Miro X, Miosge N (2009): Migratory chondrogenic progenitor cells from repair tissue during the later stages of human osteoarthritis. Cell Stem Cell $\underline{4}, 324-335$

Le Bail J, Liagre B, Vergne P, Bertin P, Beneytout J, Habrioux G (2001): Aromatase in synovial cells from postmenopausal women. Steroids $\underline{66}, 749-757$

Lecomte P, Lecureuil N, Lecureuil M, Lemonnier Y, Mariotte N, Valat C, Garrigue MA (1998): Sex differences in the control of sex-hormone-binding globulin in the elderly: role of insulin-like growth factor-I and insulin. Eur J Endocrinol 139, 178-183

Leskelä H, Olkku A, Lehtonen S, Mahonen A, Koivunen J, Turpeinen M, Uusitalo J, Pelkonen O, Kangas L, Selander K et al. (2006): Estrogen receptor alpha genotype confers interindividual variability of response to estrogen and testosterone in mesenchymal-stem-cell-derived osteoblasts. Bone $\underline{39}$, 1026-1034

Linn S, Murtaugh B, Casey E (2012): Role of sex hormones in the development of osteoarthritis. PM R $\underline{4}, 169-173$

Loeser RF, Goldring SR, Scanzello CR, Goldring MB (2012): Osteoarthritis: a disease of the joint as an organ. Arthritis Rheum $\underline{64}, 1697-1707$

Lønning PE (1998): Pharmacological profiles of exemestane and formestane, steroidal aromatase inhibitors used for treatment of postmenopausal breast cancer. Breast Cancer Res Treat $\underline{49}, 45-52$

Mahajan A, Tandon V, Verma S, Sharma S (2005): Osteoarthritis and menopause. J Indian Rheumatol Assoc 13, 21-25

Martel-Pelletier J (1998): Pathophysiology of osteoarthritis. Osteoarthritis Cartilage $\underline{6}$, 374-376 
Martin JA, Buckwalter JA (2001): Roles of articular cartilage aging and chondrocyte senescence in the pathogenesis of osteoarthritis. Iowa Orthop J $\underline{21}, 1-7$

McTernan PG, Anwar A, Eggo MC, Barnett AH, Stewart PM, Kumar S (2000): Gender differences in the regulation of $\mathrm{P} 450$ aromatase expression and activity in human adipose tissue. Int J Obes Relat Metab Disord 24, 875-881

McTernan PG, Anderson LA, Anwar AJ, Eggo MC, Crocker J, Barnett AH, Stewart PM, Kumar S (2002): Glucocorticoid regulation of p450 aromatase activity in human adipose tissue: gender and site differences. J Clin Endocrinol Metab 7, 1327-1336

Merlotti D, Gennari L, Stolakis K, Nuti R (2011): Aromatase Activity and Bone Loss in Men. J Osteoporos 2011, 1-11

Messier SP, Loeser RF, Miller GD, Morgan TM, Rejeski WJ, Sevick MA, Ettinger WH, Pahor M, Williamson JD (2004): Exercise and dietary weight loss in overweight and obese older adults with knee osteoarthritis: the Arthritis, Diet, and Activity Promotion Trial. Arthritis Rheum 50, 1501-1510

Misso ML, Jang C, Adams J, Tran J, Murata Y, Bell R, Boon WC, Simpson ER, Davis SR (2005): Adipose aromatase gene expression is greater in older women and is unaffected by postmenopausal estrogen therapy. Menopause $\underline{12}, 210-215$

Mulisch M, Welsch U: Romeis mikroskopische Technik. 18. Auflage; Spektrum Akademischer Verlag, Heidelberg 2010

Murphy L, Schwartz TA, Helmick CG, Renner JB, Tudor G, Koch G, Dragomir A, Kalsbeek WD, Luta G, Jordan JM (2008): Lifetime risk of symptomatic knee osteoarthritis. Arthritis Rheum 59, 1207-1213

Nawata H, Tanaka S, Takayanagi R, Sakai Y, Yanase T, Ikuyama S, Haji M (1995): Aromatase in bone cell: association with osteoporosis in postmenopausal women. $\mathrm{J}$ Steroid Biochem Mol Biol 53, 165-174 
Nelson HD, Humphrey LL, Nygren P, Teutsch SM, Allan JD (2002): Postmenopausal Hormone Replacement Therapy. JAMA $\underline{288}, 872-881$

Nevitt MC, Felson DT (1996): Sex hormones and the risk of osteoarthritis in women: epidemiological evidence. Ann Rheum Dis 55, 673-676

Nguyen UDT, Zhang Y, Zhu Y, Niu J, Zhang B, Aliabadi P, Felson DT (2011): Increasing Prevalence of Knee Pain and Symptomatic Knee Osteoarthritis. Ann Intern Med 155, 725-732

Nilsson O, Chrysis D, Pajulo O, Boman A, Holst M, Rubinstein J, Martin Ritzén E, Sävendahl L (2003): Localization of estrogen receptors-alpha and -beta and androgen receptor in the human growth plate at different pubertal stages. J Endocrinol 177, 319-326

Oldershaw RA (2012): Cell sources for the regeneration of articular cartilage: the past, the horizon and the future. Int J Pathol 93, 389-400

Öz OK, Millsaps R, Welch R, Birch J, Zerwekh JE (2001): Expression of aromatase in the human growth plate. J Mol Endocrinol 27, 249-253

Pfaffl MW (2001): A new mathematical model for relative quantification in real-time RT-PCR. Nucleic Acids Res 29, 16-21

Pino AM, Rodriguez JM, Rios S, Astudillo P, Leiva L, Seitz G, Fernández M, Rodriguez JP (2006): Aromatase activity of human mesenchymal stem cells is stimulated by early differentiation, vitamin D and leptin. J Endocrinol 191, 715-725

Poole AR (1999): An introduction to the pathophysiology of osteoarthritis. Front Biosci $\underline{4}, 662-670$

Prieto-Alhambra D, Judge A, Javaid MK, Cooper C, Diez-Perez A, Arden NK (2013): Incidence and risk factors for clinically diagnosed knee, hip and hand osteoarthritis: influences of age, gender and osteoarthritis affecting other joints. Ann Rheum Dis $\underline{0}, 1-6$ 
Pritzker KPH, Gay S, Jimenez SA, Ostergaard K, Pelletier J, Revell PA, Salter D, van den Berg WB (2006): Osteoarthritis cartilage histopathology: grading and staging. Osteoarthritis Cartilage 14, 13-29

Richmond RS, Carlson CS, Register TC, Shanker G, Loeser RF (2000): Functional estrogen receptors in adult articular cartilage: estrogen replacement therapy increases chondrocyte synthesis of proteoglycans and insulin-like growth factor binding protein 2 . Arthritis Rheum $\underline{43}$, 2081-2090

Rodriguez D, Morrison CJ, Overall CM (2010): Matrix metalloproteinases: what do they not do? New substrates and biological roles identified by murine models and proteomics. Biochim Biophys Acta 1803, 39-54

Roman-Blas JA, Castañeda S, Largo R, Herrero-Beaumont G (2009): Osteoarthritis associated with estrogen deficiency. Arthritis Res Ther 11, 241-257

Santen RJ, Brodie H, Simpson ER, Siiteri PK, Brodie A (2009): History of aromatase: saga of an important biological mediator and therapeutic target. Endocr Rev $\underline{30}$, 343-375

Sasano H, Frost AR, Saitoh R, Harada N, Poutanen M, Reijo V, Bulun SE, Silverberg SG, Nagura H (1996): Aromatase and 17ß-Hydroxysteroid Dehydrogenase Type 1 in Human Breast Carcinoma. J Clin Endocrinol Metab 81, 4042-4046

Sasano H, Uzuki M, Sawai T, Nagura H, Matsunaga G, Kashimoto O, Harada N (1997): Aromatase in human bone tissue. J Bone Miner Res 12, 1416-1423

Sestak I, Cuzick J, Sapunar F, Eastell R, Forbes JF, Bianco AR, Buzdar AU (2008): Risk factors for joint symptoms in patients enrolled in the ATAC trial: a retrospective, exploratory analysis. Lancet Oncol $\underline{9}, 866-872$

Shane Anderson A, Loeser RF (2010): Why is Osteoarthritis an Age-Related Disease? Best Pract Res Clin Rheumatol 24, 1-18 
Sharma L, Kapoor D, Issa S (2006): Epidemiology of osteoarthritis: an update. Curr Opin Rheumatol $\underline{18}, 147-156$

Shozu M, Simpson ER (1998): Aromatase expression of human osteoblast-like cells. Mol Cell Endocrinol 139, 117-129

Simpson ER (2000): Role of aromatase in sex steroid action. J Mol Endocrinol 25, 149-156

Simpson ER, Ackerman GE, Smith ME, Mendelson CR (1981): Estrogen formation in stromal cells of adipose tissue of women: Induction by glucocorticosteroids. Cell $\underline{78}$, 5690-5694

Simpson ER, Clyne C, Rubin G, Boon WC, Robertson K, Britt K, Speed C, Jones M (2002): Aromatase - a brief overview. Annu Rev Physiol 64, 93-127

Sowers MR, McConnell D, Jannausch M, Buyuktur AG, Hochberg M, Jamadar DA (2006): Estradiol and its metabolites and their association with knee osteoarthritis. Arthritis Rheum 54, 2481-2487

Spector TD, MacGregor AJ (2004): Risk factors for osteoarthritis: genetics. Osteoarthritis Cartilage $\underline{12}, 39-44$

Spector TD, Nandra D, Hart DJ, Doyle DV (1997): Is hormone replacement therapy protective for hand and knee osteoarthritis in women?: The Chingford Study. Ann Rheum Dis $\underline{56}, 432-434$

Srikanth VK, Fryer JL, Zhai G, Winzenberg TM, Hosmer D, Jones G (2005): A meta-analysis of sex differences prevalence, incidence and severity of osteoarthritis. Osteoarthritis Cartilage 13, 769-781

Statistisches Bundesamt (2013): Gesundheit. Fallpauschalenbezogene Krankenhausstatistik (DRG-Statistik). Diagnosen, Prozeduren und Fallpauschalen der vollstationären Patientinnen und Patienten in Krankenhäusern. Statistisches Bundesamt 12(6.4), 1-71 
Straub RH (2007): The complex role of estrogens in inflammation. Endocr Rev 28, $521-574$

Sulzbacher I (2000): Arthrose - Histologie und pathogenetische Ansätze. Radiologe 40, 1126-1133

Tanaka SY, Medicine H, Haji M, Nawata R, Tanaka S (1996): 1.25-Dihydroxyvitamin D3 enhances the enzymatic activity and expression of the messenger ribonucleic acid for aromatase cytochrome P450 synergistically with dexamethasone depending on the vitamin D receptor level in cultured human osteoblasts. Endocrinology 137, 1860-1869

Temenoff JS, Mikos AG (2000): Review: tissue engineering for regeneration of articular cartilage. Biomaterials $\underline{21}, 431-440$

Tsai CL, Liu TK (1993): Estradiol-induced knee osteoarthrosis in ovariectomized rabbits. Clin Orthop Relat Res 291, 295-302

Tuan RS, Boland G, Tuli R (2003): Adult mesenchymal stem cells and cell-based tissue engineering. Arthritis Res Ther $\underline{5}, 32-45$

Turner KJ, Macpherson S, Millar MR, McNeilly AS, Williams K, Cranfield M, Groome NP, Sharpe RM, Fraser HM, Saunders PT (2002): Development and validation of a new monoclonal antibody to mammalian aromatase. J Endocrinol $\underline{172}, 21-30$

Ushiyama T, Ueyama H, Inoue K, Ohkubo I, Hukuda S (1999): Expression of genes for estrogen receptors $\alpha$ and $\beta$ in human articular chondrocytes. Osteoarthritis Cartilage $\underline{7}$, 560-566

Valdes AM, Loughlin J, van Oene M, Chapman K, Surdulescu GL, Doherty M, Spector TD (2007): Sex and ethnic differences in the association of ASPN, CALM1, COL2A1, COMP, and FRZB with genetic susceptibility to osteoarthritis of the knee. Arthritis Rheum $\underline{56}, 137-146$ 
Vermeulen A, Kaufman JM, Goemaere S, van Pottelberg I (2002): Estradiol in elderly men. Aging Male 5, 98-102

Vincenti MP, Brinckerhoff CE (2002): Transcriptional regulation of collagenase (MMP-1, MMP-13) genes in arthritis: integration of complex signaling pathways for the recruitment of gene-specific transcription factors. Arthritis Res $\underline{4}, 157-164$

Wang M, Sampson ER, Jin H, Li J, Ke QH, Im H, Chen D (2013): MMP13 is a critical target gene during the progression of osteoarthritis. Arthritis Res Ther 15, R5

Wluka AE, Cicuttini FM, Spector TD (2000): Menopause, oestrogens and arthritis. Maturitas $\underline{35}, 183-199$

Woolf AD, Pfleger B (2003): Burden of major musculoskeletal conditions. Bull World Health Organ $\underline{81}$, 646-656

World Health Organization (2000): Obesity: Preventing and managing the global epidemic. World Health Organ Tech Rep Ser $\underline{894}$, 5-37

Zhang Y, Jordan JM (2011): Epidemiology of osteoarthritis. Clin Geriatr Med 26, 355-369

Zhou S, Zilberman Y, Wassermann K, Bain SD, Sadovsky Y, Gazit D (2001): Estrogen modulates estrogen receptor $\alpha$ and $\beta$ expression, osteogenic activity, and apoptosis in mesenchymal stem cells (MSCs) of osteoporotic mice. J Cell Biochem Suppl 155, 144-155 


\section{Anhang}

\subsection{Abbildungsverzeichnis}

$1.1 \quad$ Hyaliner Knorpel . . . . . . . . . . . . . . . . . . . . . . . 4

1.2 Bestandteile der EZM $\ldots \ldots \ldots \ldots \ldots \ldots$

1.3 Schematischer Aufbau des Gelenkknorpels $\ldots \ldots \ldots \ldots$

1.4 Durch die Aromatase katalysierte Androgenkonversion . . . . . . . . . 11

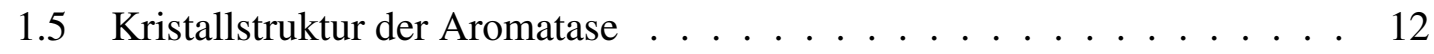

2.1 Ergebnis eines PCR-Durchlaufs $\ldots \ldots \ldots \ldots \ldots \ldots$

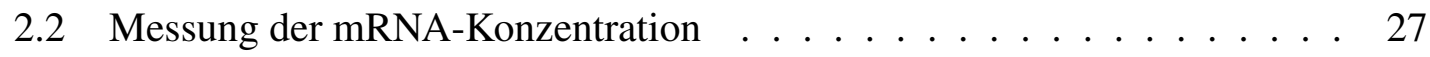

$3.1 \quad$ Immunhistochemische Detektion von Aromatase in arthrotischem Knorpel 38

3.2 Aromatase exprimierende Zellen in der Übergangszone des arthrotischen

Knorpels . . . . . . . . . . . . . . . . . . . . 39

3.3 Für Aromatase positive Zellen in hyalinem Knorpel in der OA . . . . . 40

3.4 Für Aromatase positive Zellen in fibrokartilaginärem Reparaturgewebe. . . 41

3.5 Negativkontrolle $\ldots \ldots \ldots \ldots \ldots \ldots \ldots \ldots \ldots \ldots$

$3.6 \quad$ Alginatkugel mit einem Ausschnitt bei stärkerer Vergrößerung . . . . . . 42

3.7 Coomassie-Blau-Färbung der PVDF-Membran . . . . . . . . . . 43

3.8 Antikörperreaktion gegen Aromatase bei CPC von sechs Patienten . . . . 44

3.9 Aus drei Durchläufen gemittelte Ct-Werte nach Amplifikation von Aromatase mRNA mittels PCR . . . . . . . . . . . . . . . . . . . 46

3.10 Relative Expression (Ratio) von Aromatase-mRNA in chondrogenen Pro-

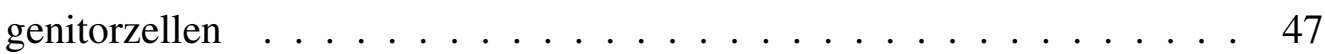

3.11 Auftragung der relativen Genexpression gegen das Patientenalter bei Knorpelentnahme . . . . . . . . . . . . . . . . . . . . . 49

3.12 Gemittelte relative Expressionen des Aromatasegens in CPC von Patienten über 67 und unter 67 Jahre . . . . . . . . . . . . . . . . . . 50

3.13 Auftragung der relativen Genexpression des Aromatasegens gegen den Body Mass Index der Patienten bei Knorpelentnahme . . . . . . . . . . 51

3.14 Relative Expression antiarthrotischer und proarthrotischer Gene nach durchgeführtem Aromatasehemmtest an CPC des weiblichen Patienten

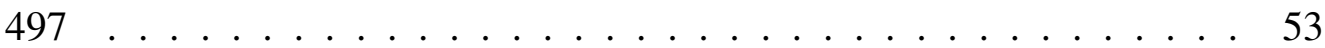


3.15 Relative Genexpression von Kollagen 1 in den CPC von vier Patienten nach Inkubation über 24 Stunden mit Formestan, Testosteron und Formestan mit Testosteron . . . . . . . . . . . . . . . . . . . . . 55

3.16 Relative Genexpression von MMP13 in den CPC dreier Patienten nach Inkubation über 24 Stunden mit Formestan, Testosteron und Formestan mit Testosteron . . . . . . . . . . . . . . . . . . . . . . 57

3.17 Relative Genexpression von Kollagen 2 in den CPC dreier Patienten nach Inkubation über 24 Stunden mit Formestan, Testosteron und Formestan mit Testosteron. . . . . . . . . . . . . . . . . . . . . . . . 59

3.18 Relative Genexpression von SOX9 in den CPC dreier Patienten nach Inkubation über 24 Stunden mit Formestan, Testosteron und Formestan mit Testosteron. . . . . . . . . . . . . . . . . . . . 60

3.19 Relative Genexpression von Aggrecan in den CPC eines männlichen Patienten nach Inkubation über 24 Stunden mit Formestan, Testosteron und Formestan mit Testosteron

\subsection{Tabellenverzeichnis}

2.1 Einbettprotokoll . . . . . . . . . . . . . . . . . . . . . . . . . . . . . 19

2.2 Auflistung der verwendeten Primer . . . . . . . . . . . . . . . . 28

2.3 Protokoll eines PCR-Laufs . . . . . . . . . . . . . . . . . . . . . . . 30

\subsection{Symbol- und Abkürzungsverzeichnis}

Abb.

ADAMTS

AP

APS

AR

BMI

CPC

$\mathrm{Ct}$

cDNA

DNA

$\Delta$
Abbildung

A disintegrin and metalloproteinase with thrombospondin motifs alkalische Phosphatase

Ammoniumperoxodisulfat

Androgenrezeptor

Body Mass Index

chondrogene Progenitorzellen

threshold cycle, Schwellenzyklus

Complementary deoxyribonucleic acid

Desoxyribonukleinsäure

Differenz 
dest.

destilliert

DMEM

Dulbecco's Modified Eagle Medium

DMSO

Dimethylsulfoxid

dNTP

Desoxyribonukleotidtriphosphat

E

Effizienz

E1

Östron

E2

Östradiol

EDTA

Ethylendiamintetraessigsäure

EZM

Extrazellulärmatrix

et al.

et alii / et aliae, und andere

FBS

fetal bovine serum

$g$

Erdbeschleunigung, $g=9.81 \mathrm{~m} / \mathrm{s}^{2}$

HEPES

2-(4-(2-Hydroxyethyl)- 1-piperazinyl)-ethansulfonsäure

HPRT-1

Hypoxanthin-Guanin-Phosphoribosyltransferase

HRT

Hormonersatztherapie

IGF

insuline-like growth factor

IL

Interleukin

MMP

Matrix-Metalloproteinase

mRNA

Messenger-Ribonukleinsäure

MSC

mesenchymale Stammzellen

$\mathrm{OA}$

Osteoarthrose

PAGE

Polyacrylamidgelelektrophorese

PBS

Phosphatgepufferte Salzlösung

PCR

Polymerase chain reaction

$\mathrm{pH}$

negativer dekadischer Logarithmus der Protonenkonzentration

PVDF

Polyvinylidenfluorid

RNase

Ribonuklease

$\mathrm{R}$

Ratio

SHBG

Sexualhormonbindendes Globulin

SDS

Natriumdodecylsulfat

TBS

Tris-buffered saline

TBS-T

TBS mit Tween-Lösung

Taq

Thermus aquaticus

TEMED

Tetramethylethylendiamin

TGF

transforming growth factor 
TRIS Tris(hydroxymethyl)aminomethan

TNF Tumornekrosefaktor

WHO Weltgesundheitsorganisation

\subsection{Chemikalien und Materialien}

Acrylamid

Ammoniumperoxodisulfat (10\%)

$17 \beta$-Mercaptoethanol

Bovine Serumalbumin

Bromphenolblau

Cytochrome P450 Aromatase Antikörper

Dako REAL Detection System

DMEM

Essigsäure

Ethanol

Eukitt Einbettmedium

Glyzin

Hämalaun

$\mathrm{HCl}$

Lumigen ECL Plus Detection System

Methanol

Milchpulver

PBS

QuantiTect Reverse Transcription Kit

RLT-Puffer

RNA Shredder

RNAeasy Kit

RW1-Puffer

SDS

SYBR-Green

TEMED

Tris
Roth (3029.2)

Roth (9592.2)

Sigma-Aldrich, (63689)

Sigma (A9647-100G)

Roth (T116.1)

AbD Serotec (MCA2077S)

Dako (K5005)

Gibcom (21885)

AppliChem (A0662)

AppliChem (2005786)

Sigma-Aldrich (03989)

Applichem (A3707)

Merck (1.09249)

AppliChem (A0658)

Lumigen (PS3-100)

Roth (4627.2)

Roth (T145.2)

Sigma (4417-100TAB)

Qiagen (205313)

Qiagen (79216)

Qiagen (1011711)

Qiagen (1011708)

Qiagen (1015763)

Fuka (71999)

Invitrogen (11733-046)

Roth (2367.3)

Roth (5429.3) 


\subsection{Geräte- und Softwareverzeichnis}

\section{Geräte}

Jung Biocut 2035-Mikrotom

Mastercycler Realplex2 S

Nano Drop 1000 Spectrophotometer

Cellometer

\section{Software}

Chemdraw 12.0

Microsoft Office 2010

Mendeley

OriginPro

STATISTICA 10

TeXnicCenter for LaTeX
Leica, Nussloch, Deutschland

Eppendorf, Hamburg, Deutschland

Thermo Fisher Scientific, Welmington, USA

Nexcelom Bioscience, Lawrence, USA

Perkin Elmer Inc., Waltham, USA

Microsoft, Redmond, USA

Mendeley Ltd., New York, USA

OriginLab Corporation, Northhampton, USA Statsoft, Hamburg, Deutschland

The TexnicCenter Team 


\section{Lebenslauf}

Mein Name ist Marcus Reinermann. Ich wohne im Nikolausberger Weg 51, in 37073 Göttingen. Geboren wurde ich am 13. September 1985 in Coesfeld.

Nach meiner Schulzeit, die ich im Juni 2005 mit der allgemeinen Hochschulreife abschloss, leistete ich von 2005-2006 meinen Zivildienst ab. Diesen absolvierte ich in der zentralen Notaufnahme und internistischen Funktionsdiagnostik des Franz-Hospitals in Dülmen. Anschließend studierte ich von Oktober 2006 bis März 2007 Chemie an der Ruhr-Universität in Bochum. Ab April 2007 begann mein Studium der Humanmedizin an der Georg-August-Universität in Göttingen, sowie (ein Semester) an der Technischen Universität in Dresden. Den Ersten Abschnitt der Ärztlichen Prüfung (Physikum) legte ich im März 2009 ab. Seit 2010 bin ich Doktorand in der Abteilung Prothetik in der Arbeitsgruppe „Orale Biologie und Geweberegeneration“ bei Herrn Prof. Dr. med. Nicolai Miosge. Von November 2011 bis Juni 2012 absolvierte ich im Rahmen meines Studium das Praktische Jahr an unterschiedlichen Krankenhäusern in den Abteilungen Chirurgie, Innere Medizin und Anästhesiologie. Den zweiten Abschnitt der ärztlichen Prüfung absolvierte ich im Dezember 2013. Seit Februar 2014 gehe ich meinem Beruf als Assistenzarzt in der Inneren Medizin, Gastroenterologie (Prof. Dr. L. Leifeld) am St. Bernward Krankenhaus in Hildesheim nach. 